\title{
DESMATAMENTO NA AMAZÔNIA: UMA ANÁLISE ECONOMÉTRICA DE AUTOCORRELAÇÃO ESPACIAL COMBINANDO INFORMAÇÕES DE SENSORIAMENTO REMOTO COM DADOS PRIMÁRIOS
}

\author{
Marcellus Marques Caldas \\ Economista \\ Orientador: Prof. Dr. RICARDO SHIROTA \\ Co-orientador: Prof. Dr. ROBERT WALKER
}

\begin{abstract}
Tese apresentada à Escola Superior de Agricultura "Luiz de Queiroz", Universidade de São Paulo, para obtenção do título de Doutor em Economia. Área de Concentração: Economia Aplicada.
\end{abstract}

PIRACICABA

Estado de São Paulo - Brasil

Janeiro - 2001 


\title{
Dados Internacionais de Catalogação na Publicação (CIP) DIVISÃO DE BIBLIOTECA E DOCUMENTAÇÃO - Campus "Luiz de Queiroz"/USP
}

\author{
Caldas, Marcellus Marques \\ Desmatamento na Amazônia : uma análise econométrica de autocorrelação espacial \\ combinado informaçōes de sensoriamento remoto com dados primários / Marcellus \\ Marques Caldas. - - Piracicaba, 2001.
}

126 p. : il.

Tese (doutorado) - Escola Superior de Agricultura Luiz de Queiroz, 2001. Bibliografia.

1. Amazônia 2. Análise espacial 3. Desmatamento 4. Sensoriamento remoto I. Titulo

CDD 333.75137

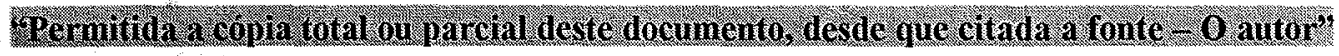

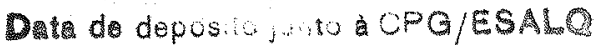

$25 / 01 / 2001$ 


\section{OFEREÇO}

À minha esposa Martha e a meus filhos, Gabriel e Amanda, que durante todos estes anos me incentivaram e encheram minha vida de alegria.

\section{DEDICO}

Aos meus pais que não mediram esforços para o meu desenvolvimento e sempre estiveram ao meu lado. Aos meus irmãos, para que se lembrem que tudo é possível, desde que se acredite. 


\section{AGRADECIMENTOS}

Ao Professor Ricardo Shirota, meu orientador e amigo, que desde o início do meu treinamento me incentivou com sua orientação segura, amizade e confiança.

Ao Professor e amigo Robert Walker, do Departamento de Geografia da Michigan State University, pela orientação no exterior, pela amizade e pelo estímulo à realização desta pesquisa. Foi uma grande honra participar de todos os trabalhos de campo como membro de sua equipe, onde aprendi na prática os ensinamentos transmitidos e a entender a importância de meu trabalho.

Ao Dr. David Skole, do Departamento de Geografia da Michigan State University e Diretor do Basic Science and Remote Sensing Initiative Laboratory, que possibilitou meu treinamento em seu laboratório, e deu-me toda a infraestrutura necessária ao desenvolvimento de minha pesquisa, através do Projeto LBA/NASA/INPE.

Ao pesquisador Walter Chomentowisk, do Departamento de Geografia da Michigan State University e do Basic Science and Remote Sensing Initiative Laboratory, pelos ensinamentos em sensoriamento remoto e sistemas de informações geográficas.

À Coordenação de Aperfeiçoamento de Pessoal de Nível Superior (CAPES-PIDCT) e à Universidade Federal da Bahia, pelo apoio financeiro.

Ao Corpo Docente do Departamento de Economia, Administração e Sociologia da ESALQ-USP, pelos conhecimentos transmitidos e, em especial ao amigo Paulo Cidade de Araújo pelos incentivos.

À todos os meus companheiros de turma, no Brasil e no exterior, com os quais tive o privilégio de conviver e muito aprender. Aos demais colegas de pós graduação, pelo apoio, amizade e agradável convivência.

Aos funcionários do Departamento que estiveram sempre prontos a ajudar: Maelli, Valdeci, Fernando, Helena, Cristiane, Pedro, Márcia, Maria Helena, Ligiana, Luciane e Elenice.

À Deus que sempre iluminou meu caminho, 


\section{SUMÁRIO}

Página

LISTA DE FIGURAS viii

LISTA DE TABELAS ix

RESUMO $\mathbf{x i}$

SUMMARY xiii

1 INTRODUÇÃO

1.1 O processo político da colonização da Amazônia 02

1.2 O problema e a importância do estudo 06

1.2.1 O papel da pequena produção nas áreas de colonização 06

1.2.2 A importância do estudo 10

1.3 Objetivos da pesquisa

1.4 Hipóteses

1.5 Local de estudos e dados utilizados

2 REFERENCIAL TEÓRICO

2.1 O Modelo de Chayanov para pequena produção agrícola familiar

2.2 Representação gráfica do modelo de desmatamento na Teoria de Chayanov

2.3 O Modelo Neoclássico da pequena produção agrícola familiar 
2.4 Representação gráfica do Modelo Neoclássico de desmatamento.

2.5 Uma proposta conceitual de integração do Modelo de Chayanov como Modelo Neoclássico aplicado ao caso amazônico

3.1 A pequena produção agrícola familiar na Amazônia

3.2 Modelos empíricos utilizados em estudos de desmatamento 46

4 METODOLOGIA

4.1 A especificação do modelo econométrico proposto

4.2 Definição das variáveis

4.3 Modelos econométricos para a correção de problemas de autocorrelação espacial

4.4 Testes de autocorrelação espacial

4.4.2 Teste dos multiplicadores de Lagrange 66

4.5 Procedimentos econométricos 
5.2 Características das propriedades: tipo de posse, crédito e assistência técnica

5.3 Relações entre as características sociodemográficas e os tipos de uso da terra 78

5.4 O modelo econométrico de desmatamento utilizado 89

5.4.1 Análise de regressão 89

6 RESUMO E CONCLUSÕES 99 REFERÊNCIAS BIBLIOGRÁFICAS 104 APÊNDICE A 115 


\section{LISTA DE FIGURAS}

Página

1 Mapa da área em estudo 14

2 Mapa Digitalizado do Projeto de Colonização de Uruará

3 LandSat WRS II Tile System apresentando número de órbita e ponto

4 Mapa digitalizado da área de colonização de Uruará sobreposto em uma imagem de LandSat TM

5 O modelo de Chayanov para a pequena produção agrícola familiar (adaptado de Ellis, 1993) 25

6 Uma representação gráfica do desmatamento usando a concepção de Chayanov

7 Uma interpretação gráfica do Modelo Neoclássico de desmatamento 


\section{LISTA DE TABELAS}

Página

1 Comparação entre as médias da amostra original e da amostra digitalizada para o Projeto de Colonização de Uruará/PA, 1996

2 Projeto de Colonização de Uruará/PA: número e porcentagem dos proprietários segundo região de origem do chefe de família, 1996

3 Estado de origem do chefe de família no Projeto de Colonização de Uruará/PA, 1996

4 Estados de residência anterior à migração para o Projeto de Colonização de Uruará/PA, 1996

5 Período médio de residência dos colonos na propriedade no Projeto de Colonização de Uruará/PA, 1996

6 Nível de escolaridade formal do chefe de família no Projeto de Colonização de Uruará/PA, 1996 73

7 Situação de pose da terra na amostra do Projeto de Colonização de Uruará/PA, 1996 74

8 Recebimento de assistência técnica no Projeto de Colonização de Uruará/PA, 1996

9 Distribuição do Crédito Rural no Projeto de Colonização de Uruará/PA, 1996

10 Utilização do Crédito Rural no Projeto de Colonização de Uruará/PA, 1996 
11 Uso de Insumos na amostra do Projeto de Colonização de Uruará/PA, 1996

12 Distribuição de Insumos no Projeto de Colonização de Uruará/PA, 1996 78

13 Relação entre tamanho da família e uso da terra no Projeto de Colonização de Uruará/PA, 1996

14 Relação entre tipo de propriedade da terra e tipo de uso da terra no Projeto de Colonização de Uruará/PA, 1996

15 Relação entre distância média e tipos de uso da terra no Projeto de Colonização de Uruará/PA, 1996

16 Relação entre o tempo de residência na propriedade e o tipo de uso da terra no Projeto de Colonização de Uruará/PA, 1996

17 Relação entre o nível de escolaridade do chefe da família e os tipos de uso da terra no Projeto de Colonização de Uruará/PA, 1996

18 Avaliação dos efeitos espaciais

19 Resultados de Mínimos Quadrados Ordinários e de Máxima Verossimilhança para o Modelo Espacial Defasado 


\title{
DESMATAMENTO NA AMAZÔNIA: UMA ANÁLISE \\ ECONOMÉTRICA DE AUTOCORRELAÇÃO ESPACIAL COMBINANDO INFORMAÇÕES DE SENSORIAMENTO REMOTO COM DADOS PRIMÁRIOS
}

\author{
Autor: MARCELLUS MARQUES CALDAS \\ Orientador: RICARDO SHIROTA \\ Co-Orientador: ROBERT WALKER
}

\section{RESUMO}

Este estudo analisa a questão do desmatamento ocorrido em áreas de colonização na Amazônia. A discussão aqui estabelecida apresenta a idéia de que as relações entre os fatores sociodemográficos, institucionais e de mercado com o desmatamento podem ser mais complexas do que se imaginava.

Esta pesquisa busca ainda preencher um espaço ainda pouco explorado na literatura que é o uso de modelos que combinam informações de sensoriamento remoto com dados primários. Além disso, considerando o tipo de dados utilizados, faz-se uma análise de autocorrelação espacial.

Os dados primários foram obtidos por meio de entrevistas diretas com pequenos produtores. Os questionários aplicados forneceram as informações sobre a estrutura e composição da família, uso da terra, fatores institucionais, etc. Em adição, utilizou-se imagens de satélite LandSat (TM) para o ano de 1997 com o intuito de se estimar a magnitude do desmatamento em cada propriedade.

$\mathrm{O}$ estudo mostra que fatores institucionais e de mercado são apenas uma parte do complexo mecanismo que explicam o processo de desmatamento. Os resultados do modelo empírico utilizado indicam que variáveis sociodemográficas que refletem estágios do ciclo de vida da família também afetam significamente a decisão de uso da terra. 
Esses resultados permitem concluir ainda que, apesar de não serem ainda muito populares entre os cientistas sociais brasileiros, os dados obtidos através das imagens de satélite podem ser muito utéis neste tipo de estudo. Além disso, a presente pesquisa apresenta forte indicação de que os modelos de desmatamento que omitem dados de mercado e sociodemográficos da família, e que não incorporem análise espacial, podem estar mal-especificados. 


\title{
DEFORESTATION IN THE AMAZON: AN ANALYSIS OF SPACIAL AUTOCORRELATION USING REMOTE SENSING INFORMATION AND PRIMARY DATA
}

\author{
Author: MARCELLUS MARQUES CALDAS \\ Advisor: RICARDO SHIROTA \\ Co-Advisor: ROBERT WALKER
}

\begin{abstract}
This study analyses the deforestation in settlement areas of the Brazilian Amazon. We discuss that the relationships among social, demographic, institutional and market factors upon the deforestation process might be more complex than previously predicted.
\end{abstract}

This research aims to fill in a gap that has not been well explored in the literature which is the use of models that combine remote sensing information with primary data. Moreover, considering the kind of data used, an analysis of spatial autocorrelation was carried out.

The primary data were obtained through the interview of small settlers. The questionnaires used provided information about household structure and composition, land use, institutional factors, etc. In addition, LandSat (TM) satellite images for the year of 1997 were used in order to estimate the deforestation magnitude in each property.

This study shows that the institutional and market factors are only part of the complex mechanism that explain the deforestation process. The results from the empirical model indicate that social and demographic variables that reflect household life cycle stages also significantly affect land use decision.

Although the remotely sensed data are not yet very popular among the Brazilian social scientists, these results confirm that they can be very useful for this kind 
of study. Furthermore, this research strongly indicates that family social and demographic data as well as market data may result in misspecification problems. The same applies for models that do no incorporate spatial analysis. 


\section{INTRODUÇÃO}

A região amazônica engloba uma área total de 7,05 milhões de $\mathrm{km}^{2}$, dos quais aproximadamente 5 milhões são cobertos por floresta tropical úmida (Sioli, 1984). Desse total, a Amazônia brasileira cobre uma área de 3,8 milhões de $\mathrm{km}^{2}$, onde se acredita haver mais de 6.000 espécies de diferentes árvores (Ducke \& Black, 1954; Pires \& Prance, 1985).

Dada sua diversidade ecológica e riqueza, o desmatamento da maior floresta tropical do mundo tem atraído a atenção da comunidade científica nos últimos anos. Conseqüentemente, considerável atenção tem sido dada à taxa de desmatamento na região, onde as estimativas divulgadas variam de acordo com o critério utilizado. Assim sendo, a taxa de desmatamento em 1989 variou entre 6\% e 12\% da Amazônia Legal ${ }^{1}$. Contudo, alguns cientistas têm argumentado que os danos causados podem chegar a 15\% (Fearnside, 1985).

Segundo Krug (1998), as últimas avaliações efetuadas por meio de imagens de satélite na Amazônia, de 1992 a 1994, conduzidas em 1996, indicam leve aumento do · tamanho e da taxa de desmatamento desde 1991. Para esta autora, desde 1994, aproximadamente $470.000 \mathrm{~km}^{2}$ de floresta primária sofreram algum tipo de transformação, representando aproximadamente $12 \%$ da área de floresta da Amazônia brasileira.

\footnotetext{
${ }^{1}$ A região amazônica brasileira é definida de duas maneiras: a região norte, a qual inclui Pará, Amazonas, Acre, Rondônia, Amapá e o Território Federal de Roraima; e a Amazônia Legal, composta pelos estados da região Norte, mais parte dos estados do Tocantins, Mato Grosso e Maranhão.
} 
Tal situação tem sido apontada como decorrente de várias causas, dentre elas, as políticas de desenvolvimento elaboradas para a região nas últimas décadas e o aumento populacional ocorrido principalmente com a migração de pequenos produtores que, juntamente com os grandes fazendeiros de gado, são apontados como os grandes responsáveis pelo crescente desmatamento. Entretanto, as tomadas de decisões de uso da terra pelos pequenos produtores na Amazônia são ainda pouco entendidas, e estes são freqüentemente acusados de levar para essa localidade práticas agrícolas utilizadas em suas regiões de origem, mas pobremente adaptadas à região amazônica.

Diferentemente de outros trabalhos sobre desmatamento em áreas de fronteira, este estudo busca entender a influência dos fatores sociodemográficos da família (estrutura e composição, idade do chefe da família, etc.), a influência dos fatores institucionais (crédito e posse da terra) e de mercado (acessibilidade ao mercado) na tomada de decisão de uso da terra (que neste trabalho conceitua-se como desmatamento), combinando informações de sensoriamento remoto com dados de levantamento primário.

Cabe aqui frisar que apesar de se reconhecer a influência de fatores macroeconômicos na tomada de decisão de uso da terra, o presente trabalho está centrado na análise da influência da estrutura e composição da família e no modo como esses fatores afetam o uso da terra.

\subsection{O processo político da colonização da Amazônia}

O desenvolvimento e a ocupação da Amazônia estão centrados no passado histórico do desenvolvimento da economia brasileira. O desenvolvimento das plantações de cana-de-açúcar no século XVI, do café nos séculos XIX e XX e da soja no século XX ocupou grandes extensões de terras no Centro-Sul e Nordeste do Brasil. Com o advento da "revolução verde" e a modernização da agricultura, a política econômica brasileira enfatizou, ainda mais, a exportação de produtos primários. Como conseqüência, grandes concentrações de terra foram formadas nessas regiões, culminando com a expulsão de 
grande número de trabalhadores do campo para a cidade. Com o golpe militar de 1964, e na tentativa de consolidar sua posição perante a opinião pública, o governo militar elaborou um plano de ação para resolver o problema da pressão populacional nas áreas urbanas. Tal plano, chamado "Operação Amazônia", objetivava incentivar o desenvolvimento e a ocupação daquela região, bem como assegurar a soberania brasileira na área ${ }^{2}$. Dessa forma, acreditava-se que o desenvolvimento da Amazônia geraria benefícios futuros para o país.

Com o avanço tecnológico e a política governamental existente no final da década de 60 e início dos anos 70 voltada à exportação de produtos primários, acentuaram-se as concentrações de terras no Sul e Nordeste do país (Hecht \& Cockburn, 1989; Mahar, 1989; Skole et al., 1994). Conseqüentemente, massas de trabalhadores sem-terra aumentaram as pressões sobre o governo por reforma agrária, que decidiu, então, como forma de aliviar as pressões existentes, dar continuidade ao plano de colonização da Amazônia iniciado com a construção da rodovia Belém-Brasília.

Para atingir esse fim, criou, em 1970, o Programa de Integração Nacional (PIN), que se fundamentava na construção de estradas que ligariam o Centro-Sul desenvolvido ao Norte subdesenvolvido e na criação de infra-estrutura. Somado a isso, grandes incentivos fiscais e creditícios serviriam para atrair empresas nacionais e estrangeiras, bem como trabalhadores rurais do Sul e do Nordeste do país.

Motivados pela perspectiva de bons lucros e pela possibilidade da aquisição de terra, deu-se a partida para a expansão da nova fronteira agrícola. Todavia, diferentemente do padrão histórico de desenvolvimento da região, com base na agricultura da borracha e no comércio, esse novo desenvolvimento estava centrado na indústria $^{3}$, no capital financeiro e na perspectiva de que a Amazônia seria a saída para as

\footnotetext{
${ }^{2}$ Para mais detalhes, ver Hecht \& Cockburn (1989).

${ }^{3}$ Segundo Hecht \& Cockburn (1989), em 1966, o governo federal elaborou um plano cujo primeiro objetivo era a ocupação regional através de pólos de desenvolvimento.
} 
pressões existentes (Hecht \& Cockburn, 1989; Mahar, 1989; Moran, 1981; Schmink \& Wood, 1984).

Neste contexto, com a ajuda do Banco Mundial e do Banco Interamericano de Desenvolvimento, a Rodovia Transamazônica, ligando o leste ao oeste da região, e a Cuiabá-Santarém foram implementadas, sendo que ao longo destas, vários projetos de colonização foram desenvolvidos como parte da estrutura planejada.

O Programa de Integração Nacional foi auxiliado pelo Proterra (Programa de Redistribuição de Terras), que tinha como objetivo a distribuição de áreas ao longo das rodovias $^{4}$. Dessa forma, pequenos produtores do Nordeste e do Sul do país foram incentivados a migrar para as áreas de colonização, na perspectiva de receberem terra $\mathrm{e}$ títulos de propriedade. O objetivo inicial do governo era assentar cerca de $100 \mathrm{mil}$ famílias em lotes de 100 hectares até 1976. Porém, até 1974, apenas 3.700 famílias tinham recebido títulos do Incra (Instituto de Colonização e Reforma Agrária) (Katzman, 1977), sendo que quatro anos mais tarde, era alcançada a marca de somente 7.900 famílias (Skillings \& Tcheyan, 1979).

Com estes números, ficava evidente o fracasso do plano governamental de colonização da Amazônia. Vários fatores contribuíram para que as metas governamentais não fossem alcançadas: impossibilidade de desenvolvimento de culturas anuais por longos períodos devido à pobreza dos solos da região ${ }^{5}$; falta de locais apropriados para armazenagem e escoamento da produção; falta de assistência técnica, entre outros (CJ JEPMA, 1995; Hecht \& Cockburn, 1989; Moran, 1981; Browder, 1994).

\footnotetext{
${ }^{4}$ Segundo Hecht \& Cockburn (1989), o PIN teve três consequiências: formalizou os planos militares de colonização da Amazônia, pelo provimento de crédito aos pequenos produtores; institucionalizou o Incra (Instituto Nacional de Colonização e Reforma Agrária), que tinha o poder de mediar as disputas por terra e a emissão de títulos; e finalmente, criou o Proterra. Segundo estes autores, esse programa possuía uma grande linha de crédito para os pequenos produtores. Contudo, seus fundos iam freqüentemente para os grandes proprietários.

Além dos objetivos sociais supostamente existentes, acreditava-se que os solos ao longo da Transamazônica, na região de Altamira, eram suficientemente fertéis (Ipean, 1967).
} 
Ressalta-se, por outro lado, que a colonização da Amazônia, não se deu apenas por meio de órgãos governamentais. Inúmeros projetos de colonização privados ${ }^{6}$ e migrações espontâneas aconteceram. No caso das migrações espontâneas, os pequenos produtores, atraídos pelas perspectivas de conseguir terras, invadiam áreas de florestas e desmatavam com o intuito de adquirir direito de posse pelo uso. O que se via, na realidade, era o aumento do desmatamento com a aplicação do sistema de agricultura itinerante "shift cultivation"?

Segundo CJ JEPMA (1995), o PIN pretendia tratar a Amazônia como um recurso de fronteira que tinha de ser explorado para benefício do país. Assim, precisarse-ia fazer um levantamento dos recursos a serem explorados. Neste sentido, vários outros programas foram criados, como o Poloamazônia (Programa de Pólos Agropecuários e Minerais da Amazônia), que objetivava a exploração e a exportação de produtos minerais, agrícolas e pecuários, em larga escala, e o Polonoroeste (Programa de Desenvolvimento do Noroeste do Brasil), que dava continuidade ao programa de ocupação da Amazônia por meio da colonização, mas com o objetivo de reduzir o desmatamento, principalmente em Rondônia, decorrente da migração indiscriminada, iniciada no século XIX, com o ciclo da borracha e durante a Segunda Guerra Mundial. Contudo, nenhum dos dois ciclos teve impacto permanente. ${ }^{8}$

Para se ter uma idéia da força do processo migratório, por volta de 1960, somente 70 mil pessoas viviam em Rondônia e cerca de três mil migravam para o estado a cada ano. Depois da construção da rodovia Cuiabá-Santarém, a migração para o estado cresceu de maneira assustadora, sendo quase dez vezes maior que aquele número dos anos 70 (CJ JEPMA, 1995). Segundo Browder (1988), depois de quase três décadas de

\footnotetext{
${ }^{6}$ Para mais detalhes, ver Almeida \& Santos (1990).

7 "Shift cultivation" é um termo que abrange uma grande gama de definições, incluindo produtores fixos em determinada área rotacionando um número fixo de lotes, como no caso dos pequenos agricultores da Amazônia. Para mais detalhes com relação à definição, ver Watters (1971).

${ }^{8}$ Para mais detalhes quanto à influência destes programas, ver Hecht \& Cockburn (1989) e Browder (1994).
} 
colonização espontânea, o governo federal iniciava uma política de ordenar a explosão demográfica em Rondônia.

Da mesma forma como na região da Transamazônica, acreditava-se que os solos ao longo da rodovia em Rondônia eram férteis (Embrapa, 1975; Silva et al., 1973). Mas, diferentemente da colonização ao longo da rodovia Transamazônica, em que o Incra pagou as despesas de locomoção dos pequenos produtores, deu oito meses de salário e construiu casas (Moran, 1981), em Rondônia, os pequenos produtores não receberam nenhuma remuneração (Browder, 1988), apenas lotes de 100 hectares e alguma infra-estrutura. Destarte, os pequenos produtores pagavam uma pequena taxa pelo título e tinham de cobrir seus custos de transporte e realocação com a venda de madeira, tornando-se elegíveis para o recebimento de crédito agrícola subsidiado (Browder, 1988). Mais uma vez, o resultado não foi o esperado. Dada a massiva migração para a região ${ }^{9}$, o desmatamento aumentou e algumas estimativas demonstraram que $26 \%$ das florestas do estado haviam sido desmatadas por volta de 1989 (Monbiot, 1995).

\subsection{O problema e a importância do estudo}

\subsubsection{O papel da pequena produção nas áreas de colonização}

A construção das rodovias Transamazônica e Cuiabá-Porto Velho e a crença de que os solos ao longo destas eram férteis, atraíram milhares de pequenos produtores para as áreas de colonização. O objetivo, como relatado anteriormente, era aliviar as pressões sociais existentes no Centro-Sul e assegurar a soberania brasileira na região. Para alcançar esse fim, os projetos também eram vistos como produtores de alimentos. $\mathrm{O}$ plano era a produção de culturas alimentícias (tais como arroz, feijão e milho) para atender à demanda local, com o excedente sendo exportado para o Centro-Sul (Moran, 1981).

\footnotetext{
${ }^{9}$ Cerca de 140.000 novos pequenos produtores estavam chegando em Rondônia a cada ano por volta de 1984 (Browder, 1988).
} 
Os solos dessas regiões, porém, não possuíam a fertilidade propagada pelos órgãos governamentais. Segundo Smith (1981), somente 3\% dos solos nas proximidades da rodovia Transamazônica, perto de Altamira, poderiam ser classificados como naturalmente férteis. Somado a isso, estavam as condições climáticas da região, caracterizadas por excessivas chuvas, que facilitavam a incidência de pragas e doenças. Conseqüentemente, tornar-se-ia indispensável o uso intensivo de fertilizantes e defensivos.

Apesar das restrições de solos desfavoráveis, os pequenos produtores assentados ao longo da Transamazônica começaram a produzir empregando o método de "derruba e queima" (Slash and Burn). Este sistema, além de limpar o solo para o plantio, incorporava, com cinzas e detritos em decomposição, os nutrientes necessários para o plantio. Esta técnica, porém, não pode ser repetida indefinidamente. Segundo Alvim (1978), quando o solo é plantado com culturas de ciclo curto, como era o caso, e não se protege completamente o terreno, os minerais incorporados com a "derruba e queima" são facilmente arrastados por lixiviação ou erosão, fazendo com que a fertilidade dos solos, em poucos anos, volte a níveis ainda mais baixos que os originais.

Entretanto, os pequenos produtores da região basearam-se na prática de derruba e queima da floresta primária, procedendo em seguida o cultivo de culturas anuais, geralmente por dois ou três anos, com conseqüente abandono das áreas por vários anos, ou mesmo décadas, para recomposição da fertilidade do solo.

Segundo Slaver (1989), a técnica de derruba e queima é a principal tecnologia empregada na produção de culturas de subsistência em regiões com grandes extensões de terras e baixa pressão populacional. Para este autor, a citada 'tecnologia' também pode ser usada no desmatamento de áreas de florestas para outros usos, principalmente pastagens e culturas permanentes, onde as culturas de subsistência são plantadas logo após o desmatamento.

Essa técnica de derruba e queima, com posterior abandono, era comum na Europa e na América do Norte quando a densidade populacional era baixa e a produção 
destinada ao uso doméstico (Boserup, 1965). Nestes casos, a terra pode ser deixada em pousio para recuperação por longo período de tempo. Todavia, quando há pressões populacionais ou surgem mudanças socioeconômicas que restringem a disponibilidade de terra, o período de pousio é diminuído, gerando um processo de esgotamento mais acelerado.

No caso da Amazônia, a agricultura de "derruba e queima" e posterior abandono dá-se de duas formas. Primeiro, na forma tradicional, tal como aconteceu na Europa e na América do Norte, com o pequeno produtor derrubando e queimando, com posterior abandono quando a fertilidade do solo decrescia; e, em segundo, dentro da propriedade. Neste caso, o pequeno produtor derruba novas áreas de floresta dentro de seu próprio "lote"10 para o estabelecimento de sistemas de produção, derrubando e queimando cada vez mais, com posterior abandono, para recomposição da fertilidade do solo, conforme suas necessidades de plantio.

$\mathrm{Na}$ Amazônia, o processo de "derruba e queima" acontece dentro de determinadas fronteiras, sem o abandono da propriedade ${ }^{11}$. Este tipo de atitude, apesar de ser mais comum entre aqueles produtores que não possuem títulos de propriedade, é prática, também, entre aqueles que os possuem. Assim, quando a fertilidade do solo decresce, os pequenos produtores movem-se para novas áreas de floresta, iniciando um novo ciclo de desmatamento (Myers, 1980; Walker, 1987; Walker \& Smith, 1993).

Para Serrão \& Homma (1993), a agricultura itinerante tem-se transformado na maior atividade para um grande número de pequenos produtores, sendo que este tipo de sistema impõe substancial perda de florestas. Conseqüentemente, os pequenos produtores são freqüentemente acusados de promover grandes desmatamentos à medida que entram nas áreas de floresta e praticam a agricultura itinerante. Segundo Serrão, Nepstad \& Walker (1996), os pequenos produtores da região amazônica são

\footnotetext{
${ }^{10}$ Lote é uma unidade fỉsica estabelecida pelo Incra na região da Transamazônica, correspondendo a 100 (cem) hectares em tamanho.

${ }^{11}$ Propriedade é, aqui, definida como composta por 1 (um) ou mais lotes.
} 
responsáveis por cerca de 30 a $35 \%$ do desmatamento. Por conseguinte, o crescente aumento do desmatamento, ao mesmo tempo em que reduz as áreas de florestas, também afeta os sistemas agrícolas das comunidades mais pobres.

Para Turner et al. (1994), os sistemas agrícolas compreendem uma diversidade de usos da terra (tais como culturas anuais, perenes, pastagens, etc.) e requerem intervenções humanas que levam a alterações na vegetação. Para estes autores, as forças direcionadoras da mudança de cobertura vegetal são decorrentes dessas ações humanas e de fatores econômicos externos. Entretanto, muitas das ações humanas são decorrentes do desenvolvimento da família, ou seja, estão relacionadas ao seu ciclo de vida ao longo do tempo.

Walker \& Homma (1996) argumentam que, com o desenvolvimento da família, decorrente dos estágios de seu ciclo de vida, e com mudanças em suas estratégias, em decorrência da evolução das condições econômicas, os sistemas agrícolas também mudam e, como conseqüência, há mudança da vegetação. Conseqüentemente, essa mudança pode afetar o "status" econômico da família pela restrição da escolha dos cultivos em decorrência da degradação ambiental.

Muito embora os fatores macroeconômicos (incentivos fiscais e creditícios, etc.) tenham sido reconhecidos como uma das importantes causas do desmatamento na Amazônia (Mahar, 1989; Hecht, 1985; etc.), pouca atenção tem sido dada aos fatores direcionadores do desmatamento em termos familiares. Portanto, além da importância dos fatores externos e da estrutura social, ao explicar os padrões de uso da terra e da mudança da cobertura vegetal, as condições internas da família têm vital importância, particularmente aquelas associadas aos recursos básicos (financeiros e de mão-de-obra). Conseqüentemente, fatores como tamanho, composição e nível de riqueza da família ganham ênfase na tomada de decisão da dinâmica de uso da terra.

Para Moran \& Brondizio (1998), a escolha do solo pelo produtor, da área a ser desmatada, o método usado para efetuar o desmatamento, o tempo de queimada, a escolha e a seqüencia das culturas a serem plantadas, bem como a freqüência da capina 
afetam a taxa a que as espécies pioneiras podem colonizar uma área. O mesmo ocorre com a composição da sucessão, que, por conseguinte, altera novas decisões de uso da terra.

Neste contexto, a relativa importância dos fatores internos e externos em afetar a mudança da cobertura vegetal é uma questão empírica, mas permanece o fato de que a pequena produção familiar é a unidade tomadora da decisão (Moran \& Brondizio, 1998). Dentro desta concepção, questões antes não levantadas, mas não menos importantes, começam a surgir. Por exemplo: qual a importância da estrutura e composição da família e dos fatores institucionais e de mercado na tomada de decisão de desmatar? Como isto afeta o padrão de desmatamento dentro da pequena propriedade familiar na região da rodovia Transamazônica?

\subsubsection{A importância do estudo}

As possíveis causas do desmatamento em países do Terceiro Mundo são bastantes conhecidas na literatura. Brown \& Pearce (1994), por exemplo, definem as forças direcionadoras do desmatamento como decorrentes da competição por terras, a qual reflete a rápida expansão populacional, e de "falhas" em trabalhar com os sistemas econômicos nacionais e internacionais. Para estes autores, a "falha" está relacionada às dificuldades desses sistemas refletirem o verdadeiro valor do sistema ambiental em uma economia de mercado. Essencialmente, muitos dos produtos florestais não são comercializados em mercados conhecidos e, como tal, são ignorados na tomada de decisão.

No caso da região amazônica, segundo CJ JEPMA (1995), a principal causa do desmatamento parte da hipótese do mecanismo de funcionamento do mercado, combinado com as falhas existentes no mercado, em que, do ponto de vista econômico, as principais características da Amazônia são abundância de terra barata e escassez de trabalho e capital. 
Já outros autores, como Fearnside (1985a), dividem as causas do desmatamento na Amazônia em fatores conjunturais (especulação, incentivos governamentais e subsídios) e estruturais (inflação, crescimento populacional e políticas governamentais). Todavia, as causas do desmatamento na Amazônia são muito mais complexas. Na verdade, estão ligadas ao padrão histórico de desenvolvimento econômico adotado. A crescente expansão populacional, a modernização da agricultura e a extrema concentração de terras são alguns exemplos de fatores socioeconômicos ligados a essa causa. Somadas a estes, estão a expansão da mineração e da exploração madeireira, a rápida urbanização e a migração para as áreas de fronteira.

Ao crescente desmatamento também estão vinculadas muitas conseqüências ambientais indesejáveis, assim como impactos socioeconômicos negativos para importantes grupos sociais (Barraclough \& Ghimire, 1990). Neste contexto, o desmatamento afeta diretamente o nível de emprego e de renda de muitas comunidades (por exemplo, seringueiros e os povos ribeirinhos), sendo que pouco se conhece a respeito das conseqüências do desmatamento sobre suas atividades.

Além disso, o desmatamento envolve um grande número de atividades humanas, com diferentes conseqüências, determinantes e agentes. Entretanto, freqüentemente, um simples indicador de desmatamento é usado. Como resultado, todo o desmatamento é contabilizado inapropriadamente com uma simples medida, sem distinção entre as várias razões de porquê o desmatamento aconteceu e quem foram os agentes responsáveis. Conseqüentemente, as políticas adotadas pelo governo ou tecnologias desenvolvidas pelos pesquisadores, podem não alcançar seus fins previstos em razão do não-entendimento dos fatores que impulsionaram as decisões.

Para Moran et al. (1996), o entendimento das condições econômicas, sociais e demográficas que influenciam a tomada de decisão dos pequenos produtores quanto a usar a floresta primária, assim como a secundária, pode significar a diferença entre sustentabilidade e devastação. 
Muito embora outras formas de organização econômica sejam conhecidas e importantes, existe uma crescente compreensão de que o papel da pequena produção na dinâmica de uso da terra esteja negligenciado (National Research Council, 1993).

Destarte, muitos dos recentes trabalhos sobre o desmatamento em países tropicais em desenvolvimento têm focalizado o desenvolvimento de políticas em nível macro, ou seja, tendem a focalizar unidades geográficas agregadas, por exemplo, regiões, estados e municípios. Isto é explicado pela disponibilidade de dados de censos e/ou sensoriamento remoto, nos quais prévios estudos sobre a dinâmica de uso da terra, geralmente, centravam-se. Somado-se a isso, há uma ausência de dados em âmbito familiar. Contudo, estes dados agregados, sozinhos, não ajudam os formuladores de política e pesquisadores a entender as forças socioeconômicas por trás das decisões de uso da terra. Como resultado, os trabalhos abordando as questões macro restringem-se às oportunidades de interpretação das questões micro, ou seja, em termos de família.

Em adição ao exposto, e diferentemente de outros trabalhos já realizados, este estudo busca preencher um espaço na literatura ainda pouco explorado, qual seja, o uso de modelos que combinam sensoriamento remoto e dados socioeconômicos primários para o entendimento dos fatores determinantes do desmatamento na Amazônia brasileira, como uma contribuição dos cientistas sociais aos estudiosos do sensoriamento remoto.

\subsection{Objetivos da pesquisa}

O objetivo geral do presente estudo está centrado no entendimento das forças microeconômicas determinantes do desmatamento que acontece em áreas de colonização, ao longo da rodovia Transamazônica, na Amazônia brasileira. Especificamente, os objetivos são:

1) Identificar os fatores geradores do desmatamento por propriedade, na área em estudo. 
2) Avaliar como os fatores sociodemográficos internos à familia, fatores institucionais (crédito e titulação) e de mercado (acessibilidade ao mercado) influenciam a dinâmica do desmatamento na área do projeto de colonização.

\subsection{Hipóteses}

A magnitude do desmatamento em áreas de colonização é função da facilidade de acesso ao mercado, da disponibilidade de crédito e da titulação da propriedade da terra, onde o acesso é medido pela distância da propriedade até a rodovia Transamazônica. Neste caso, espera-se que quanto menor a distância da propriedade para a principal rodovia de acesso, quanto maior o acesso ao crédito e à propriedade da terra, maior é o desmatamento.

A magnitude do desmatamento é função do tempo de residência na propriedade, em anos. Sendo que se espera uma relação positiva entre o tempo de residência na propriedade e a área total desmatada.

A magnitude do desmatamento é função da disponibilidade de mão-de-obra. Neste contexto, espera-se que a quantidade de mão-de-obra disponível na família tenha uma influência positiva sobre a área total desmatada.

A magnitude do desmatamento é função do nível de riqueza inicial da família, ou seja, busca-se observar se o nível de riqueza existente na família na época do assentamento tem influência na área total desmatada. Neste caso, espera-se uma relação positiva entre o nivel de riqueza e área total desmatada.

\subsection{O local de estudo e os dados utilizados}

Os dados utilizados na presente pesquisa foram gerados através de levantamento de campo efetuado no município de Uruará, no estado do Pará, uma fronteira de colonização originariamente aberta por volta dos anos 70 ao longo da rodovia Transamazônica (Figura 1). O projeto de Colonização de Uruará foi escolhido 


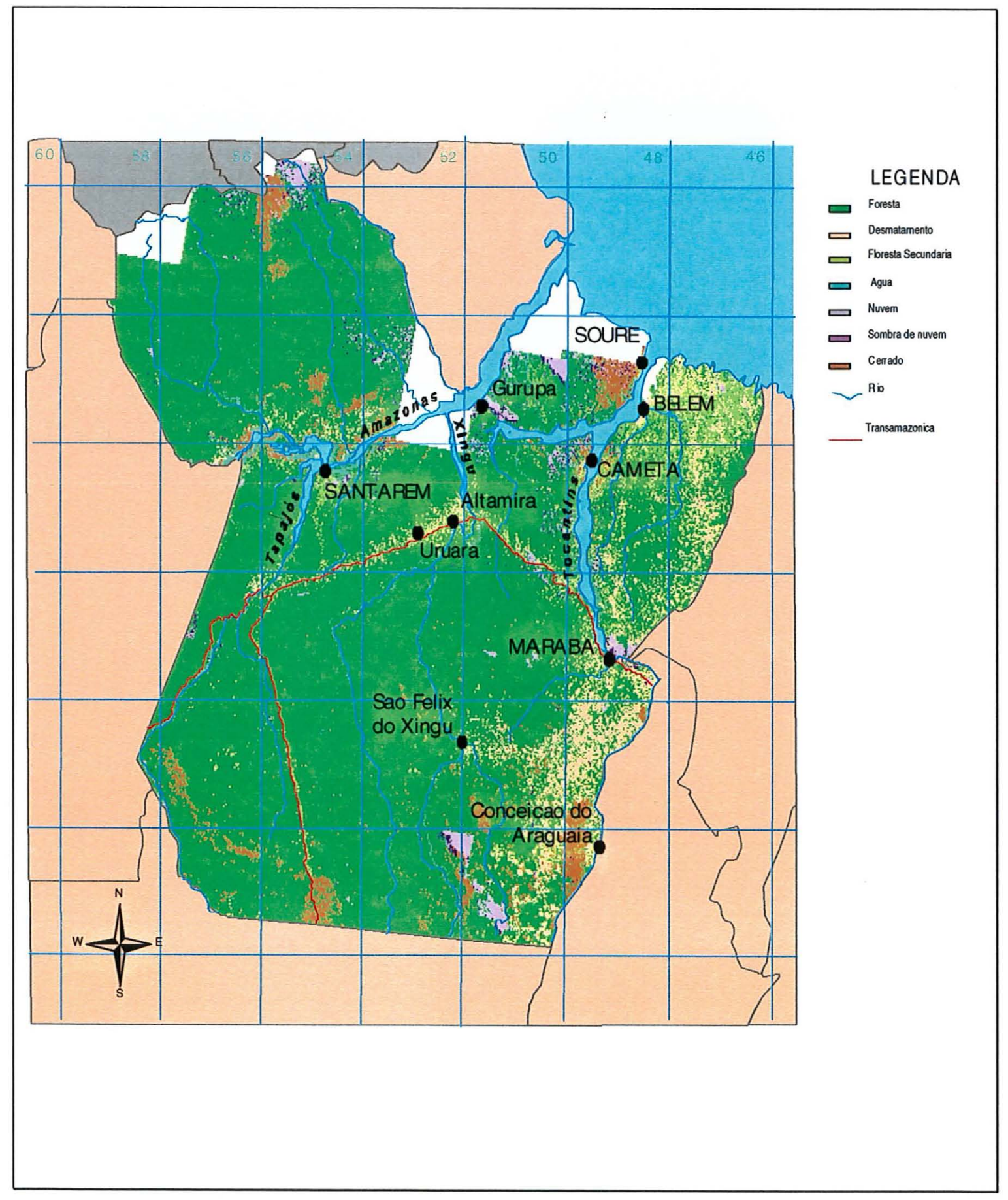

Figura 1. Mapa da área em estudo.

Fonte: Basic Science and Remote Sensing Initiative 
para o presente estudo por ser composto por uma população de produtores provenientes de programas de ocupação oficial e, também, por apresentar sinais de ocupação espontânea, com diversificação de culturas anuais e perenes, pastagens e exploração madeireira, e produtores usando tecnologias de "derruba e queima" com posterior abandono.

O município de Uruará está localizado entre os municípios de Altamira e Rurópolis com uma população de aproximadamente 37.395 habitantes (IBGE, 1996). Para este estudo, um pré-teste foi efetuado e uma amostra composta de 261 proprietários foi entrevistada em julho de 1996, cobrindo 347 lotes de 100 hectares cada, ao longo da rodovia principal e dos travessões ${ }^{12}$. Três equipes, com dois indivíduos cada, fizeram o levantamento de campo ao longo de um mês. Os questionários utilizados abordaram questões relacionadas à estrutura da família, situação socioeconômica e sistemas agrícolas.

Desde os anos 70, ocorreram algumas concentrações de posse da terra na região, o que explica a diferença entre o número de proprietários e o de lotes. Muito embora grandes fazendas já apareçam na região, a pesquisa de campo cobriu apenas pequenos produtores. Acredita-se, hoje, que Uruará tenha mais de 3.640 lotes de 100 hectares, 186 fazendas de 500 hectares (glebas) e 27 fazendas de 3.000 hectares, onde cerca de um terço dos lotes (1.257) tem o título definitivo emitido pelo Incra com os ocupantes da outra parte tendo a permissão do Incra para ocupar a terra enquanto esperam pela emissão do título.

A amostra foi coletada de forma aleatória, mas não exclui completamente certos viéses sistemáticos inerentes ao processo amostral. Isto em decorrência da dificuldade de amostrar os pequenos produtores em termos de distância. Além disto, nem sempre foi possível encontrar o proprietário no local. $\mathrm{Na}$ prática, a amostra foi coletada com base na oportunidade, combinada com a representatividade geográfica. Neste caso, foram consultados mapas e áreas que não tinham sido amostradas. Revisões

\footnotetext{
${ }^{12}$ Travessões são estradas que cortam a rodovia principal de norte a sul.
} 
diárias foram efetuadas para correção dos erros existentes na amostragem, o que possibilitou um levantamento que cobrisse a maior parte do município.

Com o mapa original da área de colonização de Uruará fornecido pelo Incra, foi efetuado a digitalização de todas as propriedades contidas no mapa, utilizando o software de informações geográficas ArcInfo (Figura 2). O objetivo desse procedimento centrava-se na localização precisa de cada propriedade amostrada, uma vez que possuíase os endereços de cada propriedade visitada, bem como dados de posição geográfica (GPS).

Dos 261 pequenos produtores amostrados, apenas 163 puderam ser localizados no mapa digitalizado, totalizando 219 lotes. A diferença entre a amostra original de 261 pequenos produtores para a amostra digitalizada de 163 deu-se em decorrência de três fatores principais. Primeiro, alguns produtores estavam assentados em lotes tão distantes da rodovia Transamazônica que nem constavam no mapa original fornecido pelo Incra na época da coleta dos dados e, conseqüentemente, não tiveram suas propriedades localizadas no mapa digitalizado. Em segundo lugar, pelo tipo de entrevista que algumas vezes foi realizada, onde vários produtores eram entrevistados num mesmo local, sem o uso do mapa do Incra, o que dificultou a exata localização da propriedade. Finalmente, alguns produtores não sabiam corretamente seus endereços.

O processo de localização das propriedades amostradas no mapa digitalizado envolveu as seguintes fases: primeiramente, efetuou-se uma compatibilização das informações fornecidas pelos produtores (número do lote, número da gleba, número do travessão) com as informações contidas no mapa fornecido pelo Incra. Em seguida, baseado no mapa do Incra, identificaram-se as propriedades amostradas no mapa digitalizado. Com base no mapa digitalizado e no mapa do Incra, realizaram-se duas viagens à área em estudo para a coleta de dados de posições geográficas (GPS), com intuito de conferir a exata localização das propriedades digitalizadas. A primeira ida ao campo ocorreu em julho de 1999 e a segunda, em julho de 2000. 


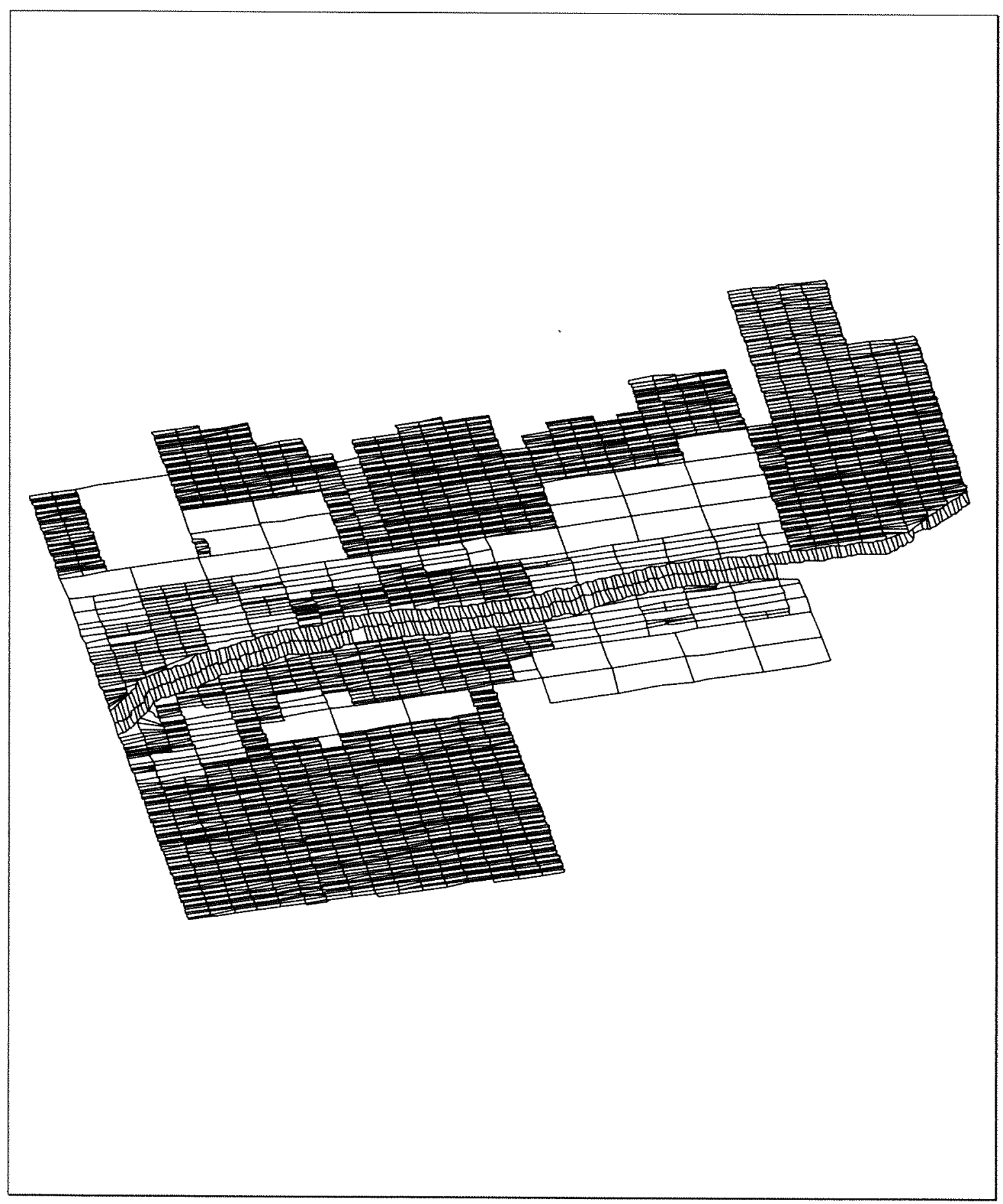

Figura 2: Mapa Digitalizado do Projeto de Colonização de Uruará. Fonte: Dados do Incra. 
$\mathrm{Na}$ terceira etapa, foram adquiridas imagens de satélite LandSat5 (TM), através do projeto NASA LandSat Pathfinder do Basic Science and Remote Sensing Initiative Laboratory da Michigan State University, para a região de Uruará (órbitas 226 e 227, ponto 62) (Figura 3), para os anos de 1996 e 1997. Todavia, neste estudo foram utilizadas apenas as imagens para o ano de 1997, uma vez que não apresentavam problemas de nuvens sobre a área em estudo, o que não ocorreu para o ano de 1996. De posse dessas imagens, observou-se que a maior parte das observações (lotes) estavam na imagem 226. Contudo, algumas observações estavam localizadas entre as duas imagens, o que nos levou a tomar a decisão de alocar a observação em uma ou outra imagem. $\mathrm{Ou}$ seja, se a maior parte da área do lote estivesse na imagem 226 , esta era computada como pertencendo à imagem 226, caso contrário, ela pertenceria à imagem 227.

Na penúltima etapa, classificaram e identificaram-se sete classes temáticas para o ano de 1997 (floresta, desmatamento, cerrado, água, nuvem, sombra de nuvem e floresta secundária). A seguir, foi efetuada uma sobreposição do mapa digitalizado da área de colonização de Uruará com a imagem de 1997 (Figura 4).

Essa sobreposição espacial possibilitou o cálculo da magnitude do desmatamento para cada lote. A partir destas informações descobriu-se que algumas propriedades tinham uma área desmatada muito maior do que o tamanho do lote, o que nos levou à conclusão de que estes lotes estavam erroneamente identificados. Conseqüentemente, a volta ao campo em julho de 2000 possibilitou a correção da exata posição daquelas propriedades que estavam erroneamente identificadas. Os levantamentos dessas informações foram, então, combinados com os dados da família, em um banco de dados. 

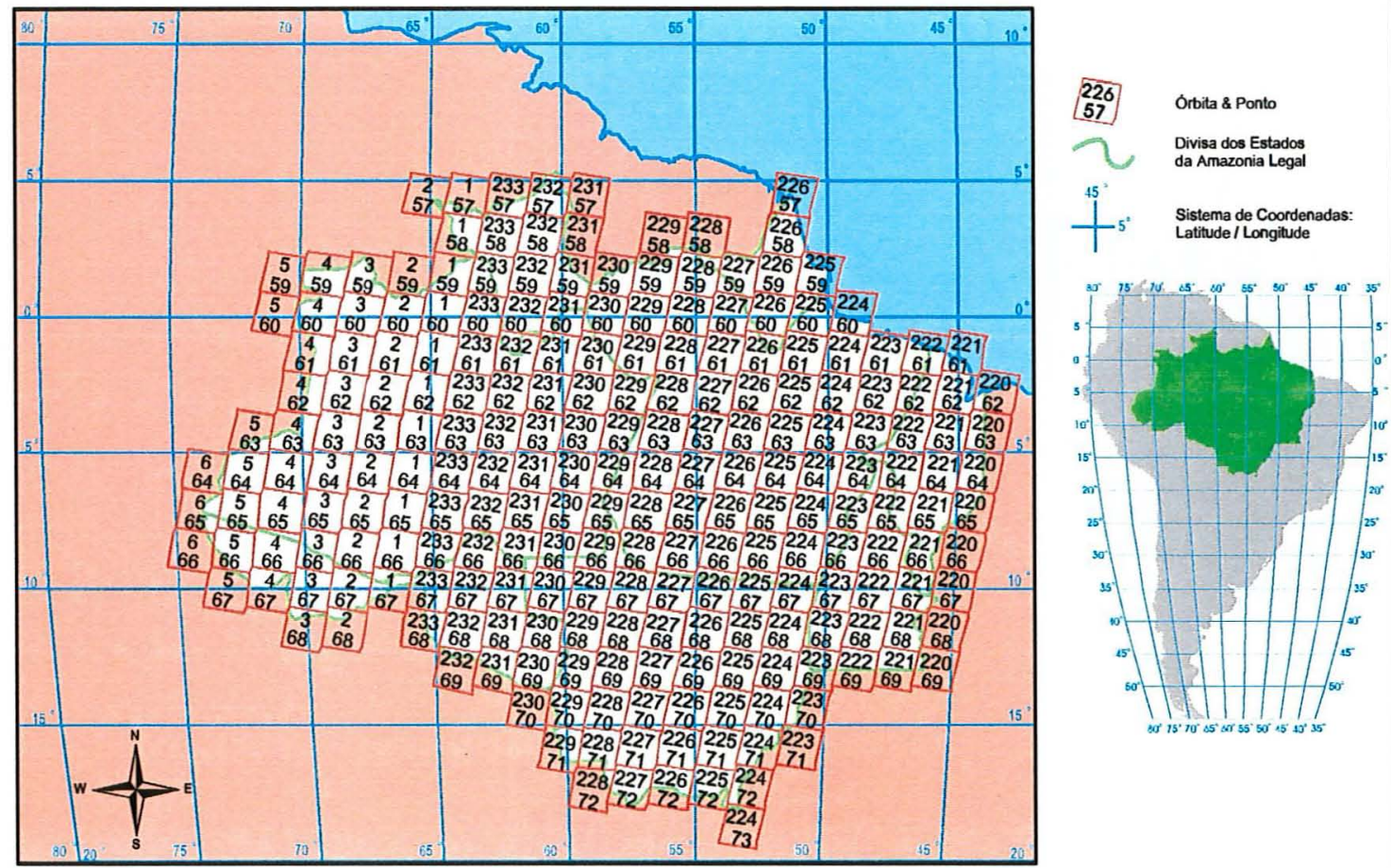

Figura 3: LandSat WRS II Tile System apresentando número de órbita e ponto. Fonte: Basic Science and Remote Sensing Initiative. 


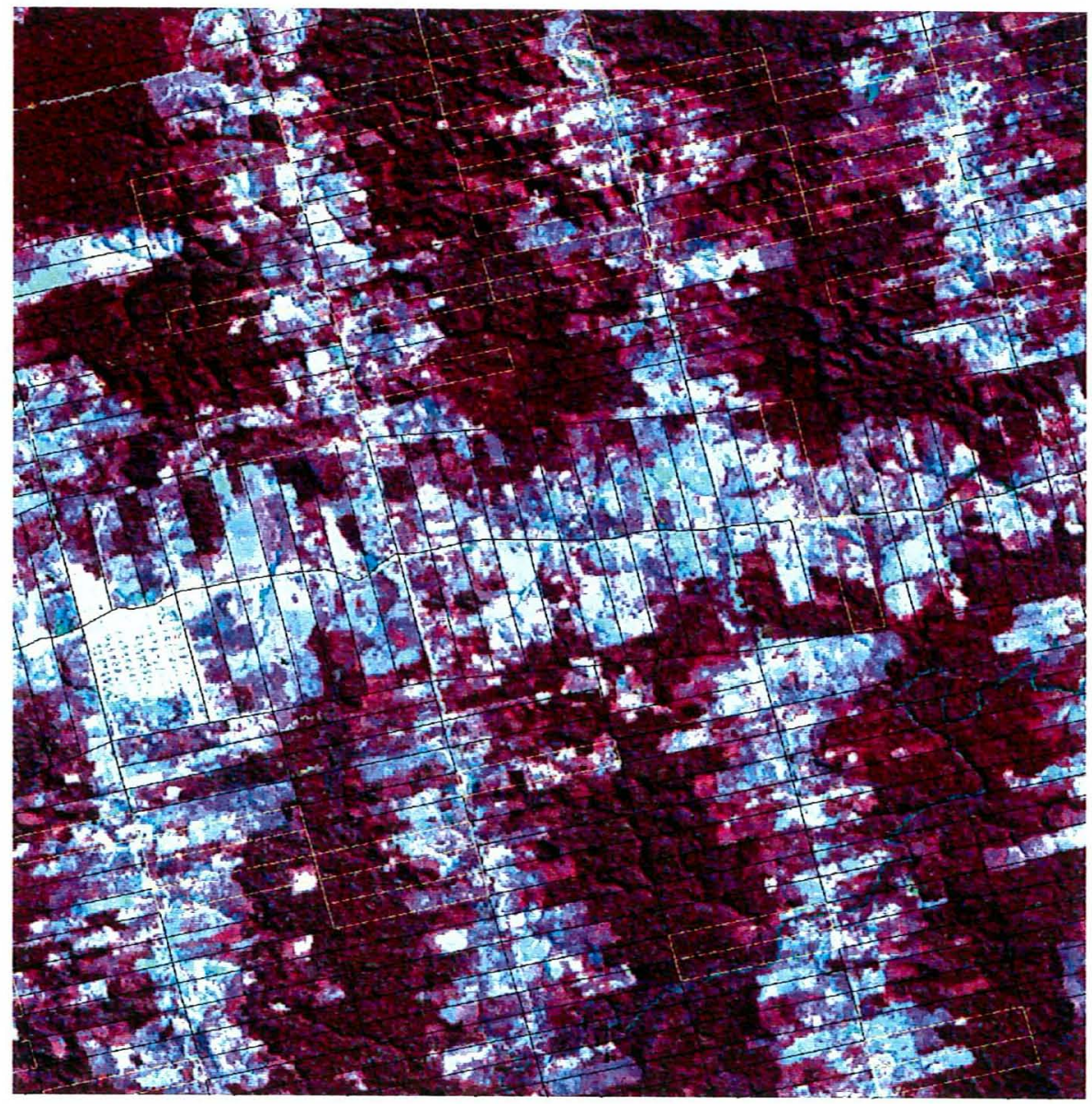

Figura 4: Mapa digitalizado da área de colonização de Uruará sobreposto em uma imagem de Landsat ${ }^{\mathrm{TM}}$. 


\section{REFERENCIAL TEÓRICO}

Dada uma variedade de teorias relacionadas à economia da pequena produção $^{13}$ familiar, duas serão vistas como as mais importantes, no contexto do presente trabalho: a teoria de Chayanov e a teoria neoclássica. Dessa forma, o objetivo do presente capítulo centra-se na apresentação desses dois modelos teóricos, com a finalidade de combiná-los teoricamente na análise do desmatamento que ocorre na Amazônia brasileira.

\subsection{O Modelo de Chayanov para pequena produção agrícola familiar}

O modelo econômico considerado nesta seção é consistente em muitos aspectos com a análise da pequena produção agrícola elaborada pelo economista agrícola russo Alexander V. Chayanov. Seu modelo está centrado na teoria da maximização da utilidade da família, focalizando-se na decisão subjetiva da família com respeito ao montante de trabalho familiar utilizado na produção a fim de satisfazer suas necessidades de consumo (Torner et al., 1986).

Para Chayanov, da mesma forma que no modelo neoclássico, essa decisão subjetiva era vista como envolvendo uma troca entre a não-utilidade do trabalho agrícola e a renda requerida para satisfazer as necessidades mínimas de consumo da família, ou seja, a utilidade da renda. Neste caso, a família tem duas posições contrárias: um objetivo de alcançar uma renda com o trabalho na propriedade; e outra de evitar o trabalho desnecessário, que conflita com o objetivo de geração de renda

\footnotetext{
${ }^{13}$ Para ter mais detalhes, consultar Singh et al. (1986).
} 
(Torner et al., 1986). Entretanto, a principal diferença para Chayanov estava centrada na não-existência de um mercado de trabalho.

$\mathrm{Na}$ teoria de Chayanov, os principais fatores que caracterizam essa troca são o tamanho da família e sua estrutura demográfica. Estes fatores são sumarizados como uma relação entre consumidores e produtores na família (Dependência). Para isso, Chayanov definiu seu conceito de família agrícola de acordo com os seguintes critérios: orientação à produção de subsistência e confiança no trabalho familiar nãoremunerado (Torner et al., 1986). Desta forma, o autor assumiu a não-existência de mercado de trabalho fora da propriedade, bem como a existência de uma norma social mínima de subsistência. Para completar, também assumiu um acesso flexível ao fator de produção terra e que toda a produção pode ser consumida ou vendida a preços de mercado. Os pequenos produtores considerados neste estudo refletem características similares, especialmente com relação ao acesso à terra. Ao contrário da maioria dos pequenos produtores das outras regiões do país, na Amazônia brasileira, eles têm fácil acesso a esse fator.

Chayanov acreditava que a atividade econômica da pequena produção podia ser melhor entendida mediante o exame da organização interna da família. Para este autor, a família era um modo único de produção e, como tal, não podia ser entendida pelas teorias econômicas existentes, uma vez que dois conceitos fundamentais ao arcabouço econômico, lucro e salário, não existiam (Torner et al., 1986).

Destarte, Chayanov serve como ponto de partida no presente contexto porque, em decorrência da revolução russa, grandes extensões de terra ficaram à disposição do governo, criando situação similar à encontrada na Amazônia. Assim sendo, Chayanov propôs que, sob condições de acesso flexível à terra, o tamanho da família e suas características demográficas determinariam a atividade econômica, incluindo o uso do trabalho e da terra. Como conseqüência, escolheu como 
características demográficas, para sua análise, o ciclo de vida do chefe da família ${ }^{14}$, o tamanho, e a presença de crianças na família.

Os dados de Chayanov sobre a Rússia, entre outros resultados, demonstram que o tamanho da família aumenta e decresce durante o ciclo de vida. Desta forma, dada a dupla função da pequena produção familiar como unidade de produção e consumo, interpretou essas mudanças de tamanho durante o ciclo de vida da família como alterações do número de consumidores e trabalhadores (ou produtores) dentro da família (Torner et al., 1986).

Como o número de consumidores e o de trabalhadores dentro de uma família variam ao longo do ciclo de vida, a relação entre estes também varia. Esta relação é comumente conhecida na literatura como Razão (ou relação de dependência) de Chayanov. Esta se inicia com valor igual a um (01), para uma jovem família sem filhos, em que existe uma igualdade entre o número de trabalhadores e consumidores. A partir do momento em que o número de consumidores ou trabalhadores é alterado, a relação também se altera. Destarte, o autor estabelece que, durante o ciclo de vida da família, aumentos na relação de dependência levam a um aumento das atividades econômicas, utilização de trabalho e auto-exploração do trabalho familiar (Tomer et al., 1986). Portanto, para ele existe uma ligação direta entre as características demográficas da família, a relação de dependência, a utilização do trabalho e o uso da terra, aqui considerado desmatamento.

Sendo assim, os elementos centrais da Teoria de Chayanov podem ser representados graficamente da seguinte maneira: seja a renda da pequena produção agrícola familiar medida no eixo vertical, onde $Y=p_{a} x_{a}$, onde $p_{a}$ é o preço do produto $x_{a}$, com o tempo total de trabalho disponível medido no eixo horizontal (determinado pelo número de trabalhadores da família). O total de tempo de trabalho pode ser alocado entre a atividade agrícola e o lazer. Desta forma, o número de horas

\footnotetext{
${ }^{14}$ Para o autor, o ciclo de vida da família começava a partir do casamento.
} 
comprometido com o trabalho agrícola pode ser medido da esquerda para a direita, OL, e o de horas dedicado ao lazer, medido da direita para a esquerda, LO (Figura 5).

O modelo contém aspectos de produção e consumo da tomada de decisão da família. O aspecto de produção é representado pela função de produção, que descreve a resposta do produto aos vários níveis do insumo variável trabalho.

Conseqüentemente, uma vez que produto e renda são sinônimos, a função de produção pode ser definida como uma curva de renda da família (Ellis, 1993). Sendo assim, a função de produção pode ser descrita como:

$$
Y=P_{a} f(L)
$$

Em outras palavras, a renda total da família é função do preço de mercado do produto e da quantidade do insumo trabalho. Por outro lado, o bem-estar no modelo de Chayanov é representado por curvas de indiferenças, $I_{1}$ e $I_{2}$, descrevendo um dado montante de utilidade total frente a diferentes combinações alternativas de lazer e produto. Essas curvas são convexas em relação à origem L, uma vez que o lazer é medido da direita para a esquerda ao longo do eixo horizontal. 


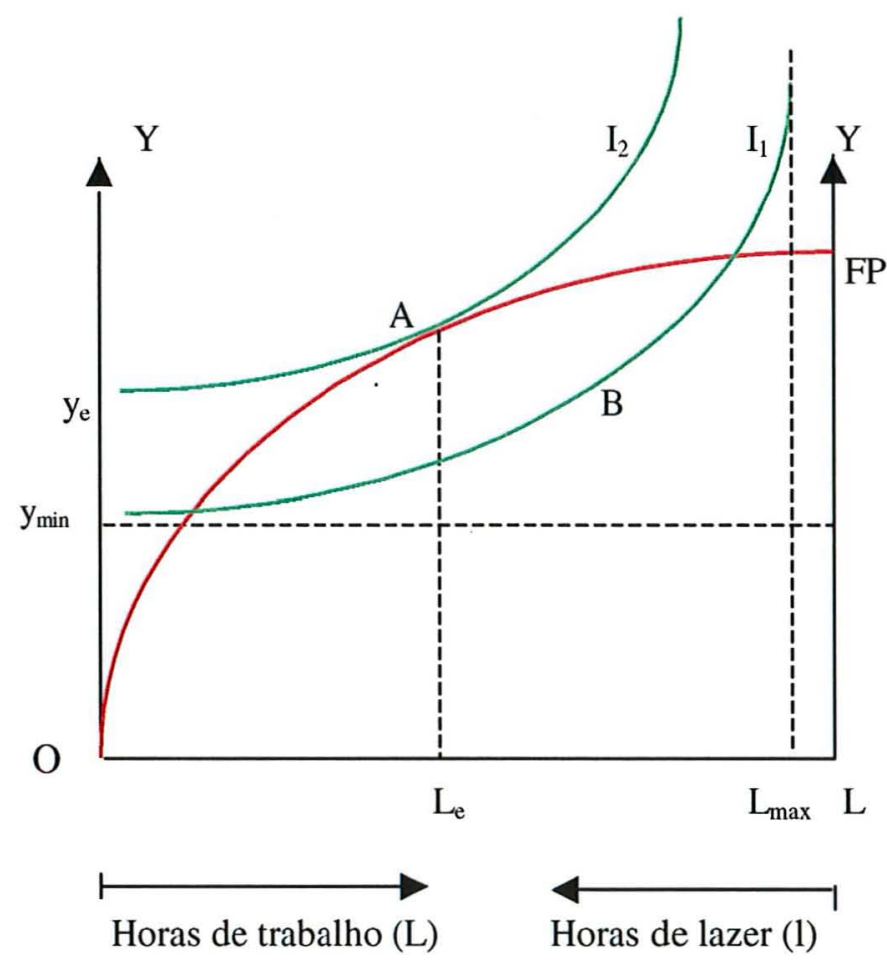

Figura 5 - O modelo de Chayanov para a pequena produção agrícola familiar (adaptado de Ellis, 1993).

Em termos de função de utilidade, pode-se dizer que a utilidade é função da renda $(Y)$ e do lazer $(l)$, tal que:

$$
U=f(Y, l)
$$

Assim, qualquer ponto sobre a curva de indiferença, como por exemplo, o ponto $\mathrm{B}$, descreve o valor subjetivo atribuído pela família ao trabalho naquele ponto. A inclinação da curva em um ponto, tal como o $\mathrm{B}$, descreve o montante de renda que a família necessitaria ganhar a fim de compensar a perda de uma unidade de lazer. Este é o nível de salário subjetivo da família (Ellis, 1993). 
Contudo, a quantidade de trabalho e o nível de renda, como indicado pelas curvas de indiferenças, são limitados pelo requerimento de que as famílias alcancem um mínimo aceitável de renda $\left(y_{\min }\right)$ e não ultrapassem o número máximo de horas de trabalho a que os membros da família podem dedicar-se em atividades produtivas $\left(L_{\max }\right)$. Destarte, observa-se que estes são claramente determinados pela estrutura demográfica da família, primeiro pelo tamanho da família, e, em segundo lugar, pelo número de trabalhadores na família. Conseqüentemente, a existência dessas restrições afeta a forma das curvas de indiferença em seus extremos (Ellis, 1993).

A posição de equilíbrio para a pequena produção agrícola é dada no ponto de tangência da função de produção com a mais alta curva de indiferença que pode ser alcançada, dada a tecnologia disponível. No gráfico, esse ponto é representado por A, com o nível de trabalho $L_{\mathfrak{e}}$ e o nível de renda $y_{\mathfrak{e}}$. Nesse ponto, o produto marginal do trabalho iguala-se ao valor subjetivo do tempo de trabalho da família $(d Y / d l)$, ou seja, é o montante de renda requerido para compensar a perda de uma unidade de lazer. Portanto, o problema econômico de Chayanov pode ser formulado em um modelo de maximização da utilidade sujeito a três restrições: (a) função de produção, (b) nível mínimo de renda e (c) quantidade máxima de trabalho disponível. De forma simples, pode ser representado como:

$$
\begin{array}{ll}
\operatorname{Max} & U=U(Y, l) \\
\text { sujeito a } & Y=P_{a} f(L) ; \\
& Y \geq Y_{\min } ; \\
& L \leq L_{\max }
\end{array}
$$


Segundo Ellis (1993), no modelo de Chayanov, o tamanho e, indiretamente, a composição da família tem importantes efeitos na posição e na inclinação das curvas de indiferença. Por exemplo, à medida que a família aumenta de tamanho, com o nascimento de crianças, o nível mínimo de subsistência aumenta, afetando a relação entre produção e consumo, em favor deste último. Todavia, com o crescimento das crianças e o posterior aumento da força de trabalho, a relação entre o número de trabalhadores e consumidores na família pode voltar a favorecer a produção. Por sua vez, à medida que os jovens adultos passam a abandonar a família, a relação entre consumo e produção pode voltar a estabilizar-se. De forma simples, essas alterações na relação entre produtores e consumidores refletem estágios do ciclo de vida da família.

\subsection{Representação gráfica do modelo de desmatamento na Teoria de Chayanov}

Graficamente, pode-se representar a forma com que as mudanças do tamanho e estrutura da família afetam o desmatamento no modelo de Chayanov com o seguinte raciocínio: suponha, primeiramente, uma função de produção com retornos marginais decrescentes, e que o número total de trabalhadores da família permaneça constante; para um tamanho de família $F_{1}$, a renda mínima de subsistência é assumida como $y_{\min }$, com o equilibrio existindo no ponto $\mathrm{A}$, em que a curva de indiferença $\mathrm{I}_{1}$ é tangente à função de produção FP; a esse ponto, a área necessária para produção é dada por $\mathrm{D}_{1}$ (a área desmatada), com uso da força de trabalho de equilíbrio $\mathrm{L}_{\mathrm{e}}$. Suponha, agora, que o número de membros da família aumente de $F_{1}$ para $F_{2}$. Com este aumento, novas condições mínimas de sobrevivência são necessárias, fazendo com que a renda mínima necessária suba de $y_{\min }$ para $\mathrm{y}_{\min }$ '. Um novo equilíbrio é estabelecido em um ponto, tal como o $\mathrm{B}$, sobre a curva de indiferença $\mathrm{I}_{2}$ (num novo mapa), e tangente à função de produção FP. Nesse nível, a família necessita de maior área para produzir $\mathrm{e}$, conseqüentemente, aumenta o desmatamento para $\mathrm{D}_{2}$, bem como a força de trabalho familiar empregada, de $L_{e}$ para $L_{e}$,', para satisfazer suas novas necessidades. Isto quer dizer que, as preferências da família mudam em decorrência da necessidade de alimentar a família. Logo, há mudança da taxa de 
salário subjetivo da família, representada por uma alteração das curvas de indiferença de $I_{1}$ para $I_{2}$. Em outras palavras, há mudanças de mapa de indiferenças (Walker \& Homma, 1996; Ellis, 1993) (Figura 6).

Para Chayanov, a pequena produção familiar não intensifica o uso do trabalho, ou aumenta a área cultivada (ou o desmatamento), apesar do aumento da força de trabalho, como faz a empresa capitalista. Para ele, a pequena unidade familiar objetiva as necessidades de subsistência, em vez de lucro. Portanto, à medida que a força de trabalho familiar aumenta, e as pressões sobre o consumo por unidade de trabalho disponível diminuem, ao longo do ciclo de vida, a utilização do trabalho e da área cultivada (ou desmatada) estabiliza-se em um ponto de equilíbrio ótimo.

Diferentemente da teoria neoclássica, para Chayanov, o mercado de trabalho não existe e a família não pode contratar mão-de-obra nem vender seu trabalho. Além disso, muito embora Chayanov observasse mercados para produtos e capital, em sua formulação teórica, assume um sistema de produção altamente restrito, centrado exclusivamente no trabalho familiar, com poucas oportunidades de expansão através de empréstimos ou reinvestimento.

Desta forma, as famílias estão restritas as suas estruturas demográficas e, face às oportunidades de mercado, as características demográficas e as pressões de consumo permanecem sendo os determinantes primários das atividades econômicas da família, da utilização do trabalho e do uso da terra. Situações semelhantes as registradas nos estágios iniciais da colonização na Amazônia, onde não existia mercado de mão-de-obra, mas que não se mantêm atualmente.

Dentro deste contexto, a principal crítica à Teoria de Chayanov está relacionada à não-existência de mercado de trabalho e, como conseqüência, à existência de um salário subjetivo, ou seja, aquele que cobre as necessidades básicas (ou mínimas) de consumo, sendo que quando este é alcançado, há uma preferência por mais lazer do que por maior consumo (Ellis,1993). 


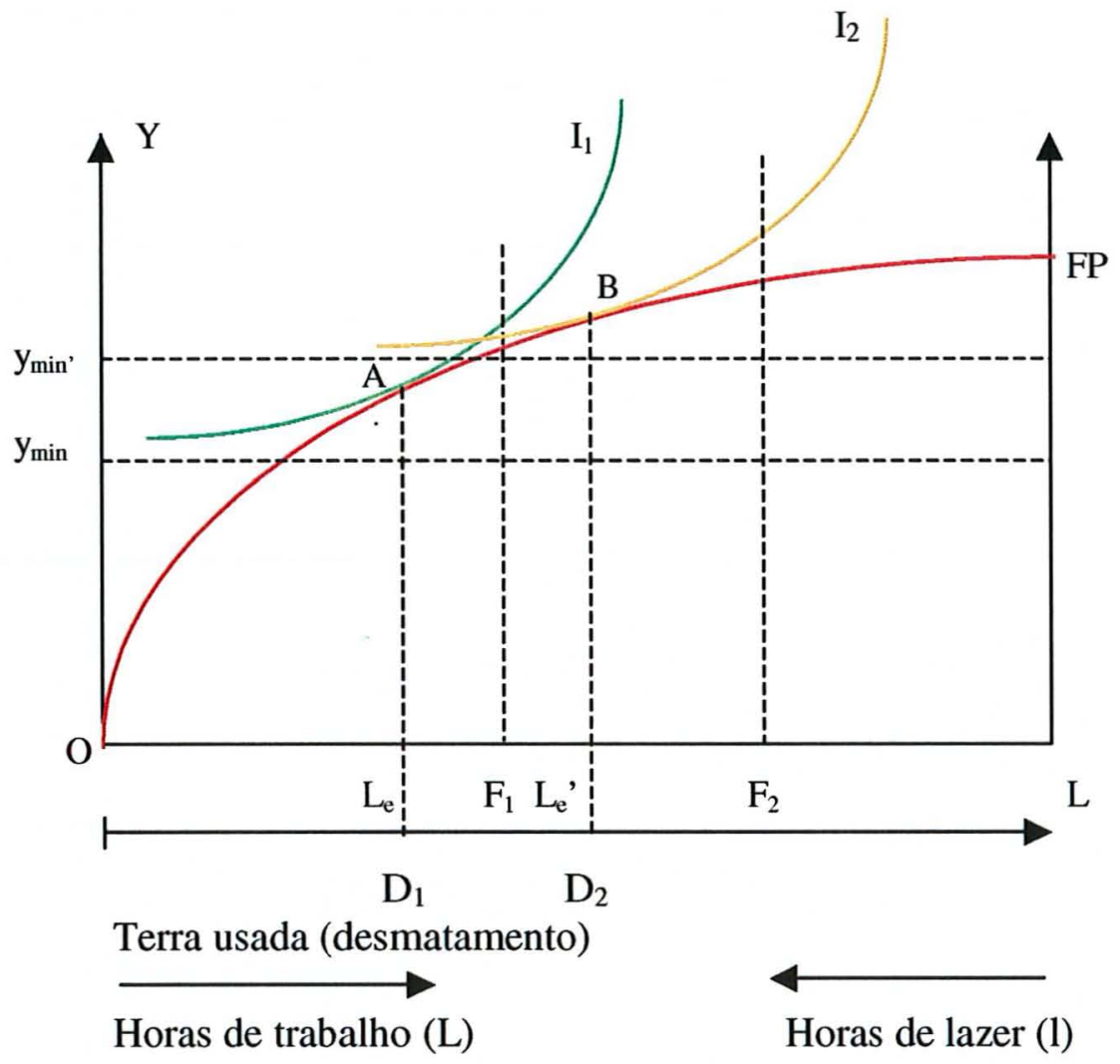

Figura 6 - Uma representação gráfica do desmatamento usando a
concepção de Chayanov.

\subsection{O Modelo Neoclássico da pequena produção agrícola familiar}

O segundo modelo, derivado da teoria econômica neoclássica, analisa a pequena produção por meio da hipótese de uma economia aberta funcionando em mercados perfeitos, buscando a maximização de uma função utilidade que represente as preferências de uma variedade de bens e serviços, sujeita a uma restrição de renda, tal que a função objetivo pode ser estabelecida como:

$$
\operatorname{Max} \quad U=U\left(x_{a}, x_{m}, x_{l}\right)
$$


onde $x_{a}, x_{m}$, e $x_{l}$ representam as quantidades de alimento, do produto comprado e do lazer. Entretanto, a utilidade é maximizada sujeita a uma restrição de renda, tal que:

$$
p_{m} x_{m}=p_{a}\left(Q-x_{a}\right)-w(L-F)
$$

onde $p_{m}$ e $p_{a}$ representam os preços unitários dos produtos comprados e do alimento, $Q$ é a quantidade produzida de alimento, tal que, $\left(Q-x_{a}\right)$ é a oferta comercializada, $w$ é o salário de mercado, $L$ o total do insumo trabalho e $F$ é o total do trabalho familiar, tal que se $(L-F)$ for positivo, então temos trabalho contratado; caso contrário, temos o total de trabalho empregado fora da propriedade. Assume-se, também, que a família está sujeita a uma restrição de tempo. Isto é, não pode alocar mais tempo para o lazer, para a produção agrícola ou para o trabalho fora da propriedade do que o total de tempo disponível da família. Tal que:

$$
T=x_{l}+F
$$

Onde $T$ é o estoque de tempo disponível da família. Destarte, a pequena produção familiar está sujeita a uma restrição de produção ou de tecnologia de produção, tal que:

$$
Q=Q(L, A)
$$

Onde $A$ é a quantidade fixa de terra da família. Cabe aqui frisar que, para simplificar, não se está considerando a possibilidade de outros insumos, tais como, fertilizantes ou pesticidas, nem a possibilidade da produção de mais de uma cultura. Além disso, assume-se que o trabalho familiar e o trabalho contratado são substitutos perfeitos e que a produção é assumida sem risco. Finalmente, e talvez o mais importante, é assumido que a família é tomadora de preços, o que permite resumir estas três restrições em uma única equação, tal que, substituindo a restrição de produção e de tempo dentro da restrição de renda, temos:

$$
p_{m} x_{m}+p_{a} x_{a}+w x_{i}=w T+\pi
$$


onde $\pi=p_{a}(Q[L, A])-w L$ é o lucro da familia. Nesta equação, o lado esquerdo representa o total de gastos da família, enquanto o lado direito representa um desenvolvimento do conceito de Becker para a renda, no qual o valor do estoque de tempo $(w T)$ da familia é explicitamente avaliado ${ }^{15}$.

\subsection{Representação gráfica do Modelo Neoclássico de desmatamento}

Tal como ressaltado anteriormente, pressupõe-se, que os trabalhos contratados e os da família são substitutos perfeitos, a produção é assumida sem risco e, o mais importante, os preços estão fixos em mercados competitivos. Neste caso, as famílias são tomadoras de preços nos três mercados, ou seja, nos de insumo, produto e trabalho.

Assim sendo, suponha que a produção (ou o consumo de alimentos) da pequena unidade familiar é medida no eixo vertical, com o total de trabalho familiar disponível (determinado pelo tempo total disponível da força de trabalho) representado no eixo horizontal, L. O tempo da força de trabalho pode ser alocado entre o lazer e a atividade agrícola na propriedade. O custo de oportunidade do tempo de trabalho é dado pelo salário de mercado w. A reta OF descreve o aumento na renda total à medida que as horas de trabalho aumentam. Portanto, o ponto $\mathrm{F}$ representa o custo de oportunidade total da família (custo de oportunidade do tempo), a preços de mercado.

O gráfico contém aspectos de produção e consumo. A função de produção representa a transformação do trabalho familiar em alimento. $O$ bem-estar é representado pela curva de indiferença I, descrevendo um dado montante de utilidade total para as diferentes combinações de lazer e alimento (produto), com a reta ww' representando o custo de oportunidade do tempo a preços de mercado.

\footnotetext{
${ }^{15}$ Para mais detalhes, consultar Silberberger (1990).
} 
$\mathrm{Na}$ Figura 7, o montante que a família está disposta a comprometer na produção de alimento é dado por $\mathrm{L}_{\mathfrak{f}}$, onde a renda $(\mathrm{Y})$ que a família está disposta a sacrificar por uma unidade a mais de lazer iguala-se ao salário de mercado. Este ponto é representado pelo ponto $\mathrm{A}$, onde a curva de indiferença tangencia a reta de custo do salário. A este ponto, a área total desmatada será $\mathrm{D}_{1}$. Ao mesmo tempo, temos no ponto $B$, o uso ótimo de trabalho na produção agrícola, $L^{*}$, onde o produto marginal do trabalho iguala-se ao salário de mercado. Contudo, observa-se que com o uso ótimo de trabalho na propriedade, a área total desmatada aumentaria para $\mathrm{D}_{2}$. Porém, neste caso, faz-se necessário a contratação de mão-de-obra assalariada, representada pela diferença entre $L^{*} e L_{f}$.

Assim, dada uma dotação inicial de recursos, tais como terra, trabalho e tecnologia, o agente econômico busca alocar seus fatores de produção de tal forma a maximizar sua produção e, como conseqüência, sua utilidade, sem influenciar os preços dos insumos e produtos que compra ou vende.

Para Kaimowitz \& Angelsen (1998), a restrição mais forte nesses modelos está na hipótese de que o mercado de trabalho atua em concorrência perfeita, em que os produtores podem vender e comprar qualquer montante de trabalho a determinada taxa de salário exógena, com o trabalho familiar sendo completamente intercambiável pelo contratado.

Entretanto, é improvável que esta hipótese seja válida em muitos contextos, principalmente no curto prazo, como no início da colonização da Amazônia, quando não havia mercado de trabalho. 


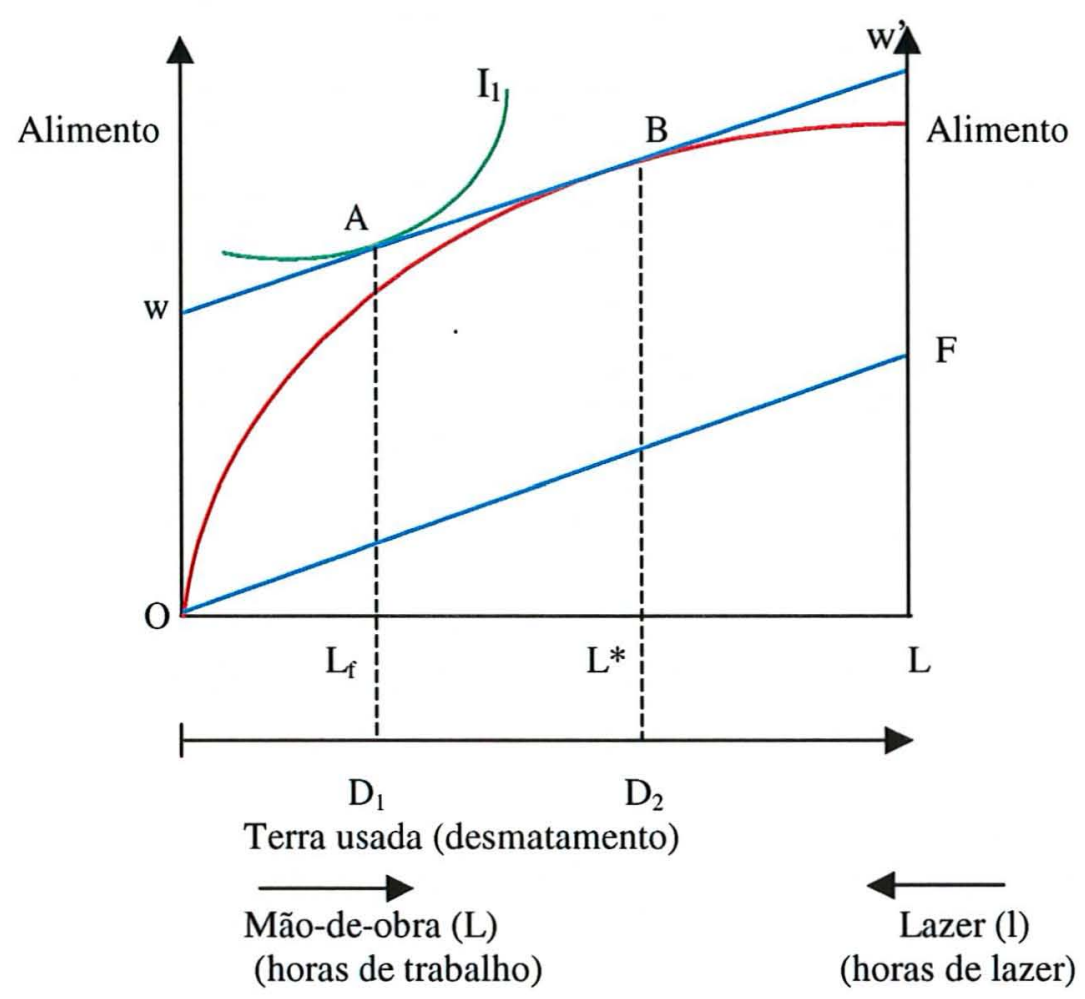

Figura 7 - Uma interpretação gráfica do modelo neoclássico de desmatamento.

Assim, se a hipótese de que as famílias interagem em mercados perfeitos simplifica a análise, também torna difícil discutir questões tais como o papel da estrutura e composição da família no uso dos recursos à medida que estes têm influência nas preferências das famílias.

2.5 Uma proposta conceitual de integração do Modelo de Chayanov com o Modelo Neoclássico aplicado ao caso amazônico

Observa-se, pelo exposto, que as duas teorias apresentam pontos importantes na tomada de decisão de uso da terra. No caso da teoria neoclássica, apesar da forte pressuposição de que os mercados de insumo e produto funcionam em 
concorrência perfeita, este tem papel importante à medida que se desenvolve, como acontece nas áreas de colonização já consolidadas.

Por outro lado, o modelo de Chayanov contribui para a explicação da tomada de decisão nas fases iniciais do processo de colonização, quando não existia mercado de mão-de-obra, e pelo fato de toda tomada de decisão ser baseada na estrutura demográfica da família. Todavia, os dois modelos isoladamente concebidos não se aplicam atualmente às áreas de fronteira da Amazônia.

Assim sendo, com o intuito de proporcionar uma avaliação empírica deste processo, faz-se necessário juntar os aspectos principais das duas teorias relatadas anteriormente. Observa-se primeiramente a existência de dois estados institucionais relativos ao mercado, ou seja, a presença de mercado e a ausência deste. Assume-se que o efeito do ciclo de vida se manifestará de uma forma autárquica (autoreguladora) quando o mercado de trabalho, insumo e produtos estão ausentes (Nakajima, 1969).

Por outro lado, a existência de mercado ocasiona uma divisão entre os atributos da família e o uso da terra. Os pequenos produtores assentados em áreas de fronteira (isto é, sem mercado e localizados nos "fundos dos travessões"16) experimentam a chegada de rodovias que abrem perspectivas para o surgimento de mercado. Neste contexto, como pode ser observado, o processo de colonização da Amazônia junta estes dois estados institucionais relativos ao mercado (a presença e ausência de mercado).

Somado a isso, no mínimo dois mecanismos relacionados ao mercado podem separar o efeito auto-regulador entre a família e seus sistemas agrícolas. Primeiramente, a família deve responder ao advento das oportunidades do mercado de trabalho e produto. Oportunidades de trabalho fora da propriedade geram salário

\footnotetext{
${ }^{16}$ Travessões são estradas que cortam a rodovia Transamazônica perpendicularmente de norte a sul, e que as vezes chegam a uma distância de até 80 quilômetros da rodovia.
} 
que podem ser usados em reinvestimentos na produção mecanizada, efetivamente substituindo capital por trabalho (o que não era possível no modelo de Chayanov).

Dessa forma, quando o trabalho é escasso, como nos estágios iniciais e finais do ciclo de vida, as famílias podem contratar trabalhadores afim de criar ou manter a propriedade. Contudo, com oferta de trabalho abundante, durante os estágios intermediários do ciclo de vida, a família pode alugar sua força de trabalho para suplementar a renda, ou acumular riqueza para investimentos futuro. Em segundo lugar, a família têm como uma das suas fontes primárias de renda a venda de produtos extrativos.

Pelo lado da demanda, observa-se que os padrões de consumo são críticos em qualquer caracterização da família e têm um papel fundamental no processo de tomada de decisão em áreas de fronteira. Estes padrões, por sua vez, são dependentes de uma função de bem-estar, que refletem os valores que as famílias atribuem aos bens e serviços que consomem, e que ao longo do ciclo de vida mudam conforme as necessidades da família, afetando, por sua vez, o uso da terra. Em áreas de fronteira, o bem-estar provavelmente depende de poucos itens, dado o baixo nível de renda e a falta de acesso ao mercado de produtos. Em termos teóricos, a escolha da família está restrita ao consumo de alimentos e ao lazer (Ellis, 1993).

Neste caso, no decurso do ciclo de vida, a função de bem-estar da família muda à medida que esta evolui e, sob a forma auto-reguladora, necessariamente afeta os atributos da família e os sistemas agrícolas. Por exemplo, o mesmo número de trabalhadores pode aumentar sua área de terra cultivada com o intuito de alimentar uma família com maior número de crianças e idosos. Se assim for, tal efeito em termos teóricos pode ser avaliado através de uma mudança na função de bem-estar e, em particular, por uma mudança entre o tempo gasto na produção de alimentos e tempo consumido em lazer.

Por outro lado, pode-se também identificar dois atributos da família afetando as decisões de uso da terra, quais sejam: os fatores produtivos da família e a 
função de bem-estar. No caso dos fatores produtivos da família, o atributo principal é a força de trabalho familiar, mas que também podem incluir o capital humano e a capacidade financeira da familia.

Em trabalhos empíricos, a função de bem-estar é analisada através do conceito de dependência, tipicamente tomado como algum indicador da demanda vis$\grave{a}$-vis os recursos produtivos. Além disto, a idade do chefe de família é tomada como um indicador do capital humano, resultado do processo de aprendizagem, que leva à aquisição do conhecimento e ao aumento da produtividade. Somado a isso, temos as atitudes de risco associadas à idade do chefe de família e o valor do consumo futuro representado pela taxa de desconto.

Para o caso dos pequenos produtores em áreas de colonização na Amazônia, investimentos mais cedo podem ser problemáticos devido à alta dependência e à limitada força de trabalho, o que colocam o produtor face-a-face com altas taxas de desconto e aversão ao risco (Walker \& Homma, 1996). Então, nas fases iniciais, os sistemas agrícolas podem ter-se centrado em produtos de subsistência, tais como arroz, milho e feijão. Somente com a participação das crianças na força de trabalho familiar a taxa de desconto diminui, assim como a aversão ao risco, o que leva a família a investir em atividades mais lucrativas, tais como culturas perenes.

Assim, estamos agora em condições de elaborar um arcabouço teórico sumarizando os fatores em nível de família que afetam as tomadas de decisões de uso da terra em áreas de fronteira. Neste contexto, à medida que os pequenos produtores iniciam suas famílias e começam a produzir, preocupam-se primeiramente em atender as suas necessidades de subsistência com os limitados recursos econômicos que possuem, dado que as crianças são estritamente consumidoras.

Dependência, aversão ao risco e alta taxas de desconto criam fortes incentivos para que se busque assegurar a subsistência através do plantio de culturas anuais. Contudo, à medida que as crianças crescem e passam a fazer parte de força de trabalho familiar, juntamente com a experiência adquirida pelo chefe de família, as 
restrições de produção são relaxadas, as taxas de desconto diminuem e a aversão ao risco também decresce. Neste caso, no estágio seguinte, a família procura investimentos mais lucrativos em culturas comerciais, tais como culturas perenes ou pecuária. Para sumarizar, é possível observar ligações entre os estágios do ciclo de vida e as tomadas de decisões de uso da terra.

Além disso, cabe aqui frisar que outros fatores podem influenciar e complicar a articulação dos impactos do ciclo de vida na tomada de decisão de uso da terra, como por exemplo, fatores institucionais (crédito, titulação e a acessibilidade ao mercado) e econômicos que não são considerados na teoria de Chayanov. A disponibilidade de crédito e a titulação em áreas de fronteira podem afetar a tomada de decisão de uso da terra. Pequenos produtores com acesso ao crédito e à titulação da propriedade na época do assentamento podem ter seguido decisões de uso da terra diferentes daqueles que não tiveram crédito ou sua área titulada. Podem, por exemplo, ter optado pelo plantio de culturas perenes e pastagens. Da mesma forma, a acessibilidade ao mercado e tempo de residência na propriedade podem ter influenciado a alocação dos fatores de produção e como conseqüência influenciado a escolha dos sistemas agrícolas. Neste caso, o tempo de residência, pode ter influenciado diretamente a degradação do solo, e como conseqüência, influenciado a tomada de decisão de uso da terra, aspectos também não abordados na teoria de Chayanov.

Observa-se que o modelo conceitual utilizado no presente trabalho não está restrito ao modelo de Chayanov nem ao modelo neoclássico, pelo contrário. Reúne variáveis que tratam tanto aspectos relacionados à teoria de Chayanov (estrutura demográfica e dependência) quanto aspectos ligados à teoria neoclássica (nível de riqueza, acessibilidade ao mercado, trabalho contratado, etc.), uma vez que é possível observar em áreas de fronteira da Amazônia pequenos produtores inseridos em ambos modelos. 


\section{REVISÃO DE LITERATURA}

Nesta parte da pesquisa são analisados os trabalhos que abordam a questão sociodemográfica da familia, principalmente com relação à estrutura e composição, e como esta influencia a tomada de decisão de uso da terra. Posteriormente, abordam-se alguns estudos que tratam das forças institucionais e de mercado na explicação dos processos de desmatamento. Finalmente, são abordados os diferentes modelos empíricos que foram utilizados nos estudos das causas do desmatamento e como alguns destes estudos estão relacionados ao sensoriamento remoto.

\subsection{A pequena produção agrícola familiar na Amazônia}

Uma extensiva literatura desenvolveu-se na presente década abordando a questão das colonizações nas áreas de fronteiras na Amazônia (veja, por exemplo, Hiraoka \& Yamamoto, 1980; Moran, 1981; Mahar, 1989; Schmink \& Wood, 1993; Brown \& Pearce, 1994; Almeida \& Campari, 1995; Mahar \& Ducrot, 1998). Entretanto, parte destes estudos está centrada em análises em macroescala, tais como tendências de desenvolvimento, migração para áreas de fronteira, impactos ecológicos, incentivos fiscais e creditícios, direitos de propriedade, etc.

Em contraste, poucos são os trabalhos que abordam os fatores em microescala, tais como os sociodemográficos (estrutura e composição da família, idade do chefe da família, etc) que influenciam o uso da terra em áreas de colonização, provavelmente, devido à limitada disponibilidade de dados dessa natureza. 
Dentre os poucos trabalhos presentes na literatura, Pichón (1993), estudando áreas de colonização no Equador, observou que os pequenos produtores equatorianos migravam para as áreas de florestas com toda a família. Para o autor, uma família mais numerosa poderia ajudar na manutenção e reivindicação da terra, sob condições de colonização espontânea. Outro fator considerado estava ligado ao fato de, sendo o Equador um país de dimensões menores que o Brasil, a migração conjunta da família para a fronteira seria mais fácil. Esse estudo considerou também a forma com que as características demográficas e socioeconômicas da família afetavam a área destinada aos diferentes tipos de uso da terra (por exemplo, culturas anuais, perenes, pastagens e florestas).

Neste caso, constatou-se que a necessidade de subsistência e o tamanho da família estavam significativamente associados com maiores áreas desmatadas, grandes parcelas destinadas a culturas perenes e pastagens e menores áreas com florestas. Além disso, a capacidade da força de trabalho e o uso de trabalho assalariado também estavam associados a maiores áreas desmatadas. Por conseguinte, constatou que o tempo de residência na propriedade estava negativamente associado à área total com florestas. Ou seja, quanto maior o tempo de residência na propriedade, menor era a área total com florestas.

Observou também que a relação de dependência da família estava negativamente associada à área total com florestas. Por outro lado, quando analisou a questão dos fatores institucionais e de mercado, constatou que a titulação da propriedade e a acessibilidade ao mercado tinham um efeito positivo sobre a área total com florestas. Isto é, quanto maior a distância a ser percorrida até o mercado, maiores eram as probabilidades das áreas permanecerem em floresta. Portanto, uma das maiores conclusões do estudo demonstrava que as características demográficas e socioeconômicas da família tinham grande impacto sobre a dinâmica de uso da terra, mas que fatores institucionais e de mercado também deveriam ser considerados. 
Segundo Marquette (1998), um maior conhecimento das relações entre as características sociodemográficas das famílias de pequenos produtores proveria importantes conhecimentos em interpretar e prever os futuros padrões de desmatamento.

Diferentemente do trabalho anterior, a autora criou uma tipologia de usos da terra (área desmatada, por exemplo) para a Amazônia equatoriana e a considerou com relação às características da família (nuclear ou estendida), segundo suas posições nos diferentes estágios no ciclo de vida ${ }^{17}$. De uma maneira geral, seus resultados são semelhantes aos anteriores, com relação às características demográficas da família. Sua análise sugere que o trabalho familiar tem um positivo efeito sobre o desmatamento somente nos estágios iniciais do ciclo de vida, nos dois casos analisados. Por outro lado, observou que o trabalho assalariado tem um efeito positivo sobre o desmatamento somente nos últimos estágios, em ambos tipos de família.

Contudo, os seus resultados demonstram que o tempo de residência na propriedade tem efeitos diferentes entre os dois tipos de família. Ou seja, os efeitos do tempo de residência são positivos e mais significantes para as famílias nucleares do que para as famílias estendidas. Para ela, faltavam às famílias estendidas meios de produção e oportunidades de trabalho fora da propriedade.

Através de diferentes pontos de vista, a literatura sobre a colonização de áreas de fronteiras tem procurado enfatizar a importância de visualizar o desmatamento como uma combinação de diferentes fatores. Neste contexto, Pichón (1997) procurou combinar fatores agronômicos, institucionais e sociodemográficos com o intuito de determinar a velocidade e o padrão com que o processo de colonização acontece em áreas de fronteira na Amazônia equatoriana.

Este autor, constatou que a qualidade do solo, a topografia, o nível educacional do chefe da família, o tempo de residência na propriedade, a disponibilidade de trabalho familiar e a qualidade da infra-estrutura rodoviária tinham significante

\footnotetext{
${ }^{17}$ O ciclo de vida neste trabalho foi medido através da idade do chefe da familia.
} 
influência no desmatamento e na subseqüente estratégia de uso da terra. Dessa forma, observou que solos de boa qualidade estimulavam os produtores a desmatar mais áreas com florestas para plantio de culturas anuais e perenes. Por outro lado, áreas com topografias desfavoráveis estimulavam a manutenção das florestas.

Com relação ao tempo de residência na propriedade, mesmo após controlar suas análises para a qualidade do recursos naturais, Pichón (1997), constatou que o tempo de residência afetava positivamente a área desmatada. Por outro lado, quando buscou analisar a questão da influência de fatores institucionais e de política, constatou, tal como seu estudo anterior, que a infra-estrutura e a acessibilidade ao mercado também afetavam significamente o uso da terra. Além disso, verificou que o nível educacional do chefe da familia tinha um surpreendente efeito positivo no desmatamento, que podia ser interpretado como evidência de que a educação estimulava o desejo de consumo e a produção das famílias como formas de melhorar o padrão de vida.

Por outro lado, e dentre o limitado número de trabalhos realizados em áreas de colonização na Amazônia brasileira e diferentemente do trabalho de Pichón (1993), Sydenstricker \& Vosti (1993), estudando famílias de pequenos produtores no projeto de colonização de Machadinho, em Rondônia, demonstraram que durante os anos iniciais do assentamento as famílias de pequenos produtores eram compostas pelo chefe da família e seus filhos, sendo que, ao longo do tempo, o tamanho da família aumentava com a inclusão de esposas e filhas.

Segundo estes autores, o período de tempo no projeto e a forma de seleção no processo de migração tinham um efeito sobre as características demográficas da família e, conseqüentemente, sobre a forma de uso da terra. Isto é, observaram que nas fases iniciais do projeto, o desmatamento da floresta primária requeria grandes quantidades de mão-de-obra, principalmente masculina. Conseqüentemente, nesses estágios, as famílias eram compostas, principalmente, pelo chefe da família e parentes, prevalecendo famílias de tamanho reduzido. Contudo, nos estágios posteriores, após o 
desmatamento, surgem outras atividades relacionadas à agricultura, nas quais crianças e mulheres participavam.

Os autores verificaram que o tamanho e a composição da família tinham impactos sobre o desmatamento. Quanto maior a quantidade de homens adultos, maior o desmatamento. Em adição, notaram que o uso do trabalho contratado estava positivamente relacionado à área total desmatada.

Tal como os estudos anteriores, Brasil \& McCracken (1993), estudando dados de diferentes tipos familiares e atividades de extrativismo/agricultura na llha de Marajó, no Pará, observaram que uma família com crianças apresenta alta dependência alimentar, reduzida força de trabalho e, relativamente, muitas atividades econômicas. Todavia, nas famílias consolidadas, isto é, contendo apenas adultos e jovens, a força de trabalho é maior, a dependência alimentar é menor e a diversidade de atividades é reduzida.

Diferentemente dos trabalhos anteriores e concentrando-se nos aspectos dinâmicos da evolução dos sistemas agrícolas, Bonal et al. (1993) estudaram a relação que existe entre escolha de sistemas agrícolas e estágios do ciclo de vida das famílias, usando dados de pequenos produtores para o norte de Goiás. Estes autores classificaram 89 propriedades dentro de nove sistemas usando análise fatorial. Como resultado, demonstram que o processo de acumulação da família é função da disponibilidade de recursos produtivos, principalmente da força de trabalho, e que isto está relacionado aos estágios do ciclo de vida. A pesquisa demonstrou que nos estágios finais do ciclo de vida, a família pode retornar aos sistemas agrícolas dos estágios iniciais em decorrência da redução da força de trabalho. Ou seja, a família pode optar por sistemas de produção poupadores de mão-de-obra.

A existência de uma relação entre os sistemas de produção adotados pelos produtores e as transformações verificadas na cobertura do solo foram também analisadas por Walker \& Homma (1996). Neste estudo, os autores baseiam-se na teoria de Chayanov para criar uma análise teórica combinando o uso da terra com as 
características demográficas da família, dentro do ciclo de vida. Todavia, na teoria de Chayanov existem várias hipóteses que dificultam uma direta aplicação ao contexto amazônico brasileiro. Por exemplo, Chayanov assume que não existe mercado de mãode-obra, assim, a família não pode contratar nem vender sua força de trabalho. Destarte, apesar de reconhecer a existência de mercado de insumos, produtos e de crédito, limita a possibilidade de geração de renda ou investimento fora da família. Além disto, seu modelo considera a existência de um sistema de produção uniforme, onde o sistema varia somente com respeito ao tamanho da propriedade (Torner et al., 1986).

Para Walker \& Homma (1996), nenhuma dessas hipóteses se mantém no caso amazônico. O mercado de trabalho existe e as famílias de pequenos produtores regularmente contratam mão-de-obra, vendem sua força de trabalho ou até mesmo trocam dias de trabalho. Somado a isso, o capital e o crédito agrícola estão disponíveis, apesar de difícil acesso, com parte da produção freqüentemente sendo vendida no mercado.

Para superar estas limitações, os autores estabelecem uma adaptação teórica do modelo de Chayanov ao caso amazônico. Observam que as diferentes condições econômicas dentre as famílias estão ligadas aos diferentes sistemas agrícolas e às características demográficas da família ao longo do tempo. Para eles, o processo amazônico começa com a chegada de uma jovem família de colonos (pais e crianças) a uma parcela de terra contendo floresta primária. Neste primeiro estágio, os colonos geralmente produzem culturas anuais (arroz, feijão, milho e mandioca), uma vez que há alta dependência alimentar e poucos trabalhadores, e dado que as culturas anuais constituem estratégias agrícolas de baixo risco, uma vez que produzem rapidamente após o plantio.

Contudo, à medida que as crianças crescem e a família ganha experiência, a família pode assumir mais riscos e novos sistemas agrícolas orientados para o mercado podem ser utilizados, tais como culturas perenes (cacau, pimenta-do-reino e café). Entretanto, à medida que o tempo passa e o chefe da família envelhece, as atividades 
agrícolas podem se contrair, podem manter-se ou até mesmo expandir-se, caso os filhos adultos permaneçam na propriedade.

Walker \& Homma (1996), em seu modelo teórico, também reconhecem a importância de uma variedade de fatores econômicos que influenciam as decisões de uso da terra, tais como o nível de riqueza inicial, a disponibilidade de crédito e de mercado de trabalho.

Assim, constata-se pelo exposto que todos os trabalhos anteriores centraramse, de uma maneira geral, em análises empíricas ou teóricas de como a estrutura e composição da família, dentro do ciclo de vida, influenciava a mudança da cobertura vegetal. Além disso, ressaltaram em alguns casos a importância de se combinar fatores sociodemográficos com fatores institucionais e de mercado. Entretanto, observa-se em todos os trabalhos expostos não haver uma integração com outros campos da ciência. $\mathrm{Ou}$ seja, são análises que se baseavam em métodos estritamente relacionados às ciências sociais. Contudo, tal como ressaltado por Pichón (1997), as análises sobre desmatamento devem considerar não somente os aspectos socioeconômicos e demográficos isoladamente, mas também fatores naturais nos quais a atividade agrícola está inserida.

Neste contexto, uma distinta característica já se faz presente na recente literatura sobre o desmatamento em áreas de fronteira. Esta recente literatura ${ }^{18}$ procura enfatizar a necessidade de se promover multidisciplinares estudos nas análises ambientais, combinando ciências sociais e ciências naturais. Assim, dentro desta nova linha de estudos, McCraken et al. (1999), utilizando o modelo teórico proposto por Walker \& Homma (1996), analisam os elos existentes entre uma mudança que acontece em uma paisagem com a dinâmica demográfica familiar em áreas de colonização na região de Altamira, no estado do Pará.

A hipótese central de seu estudo procurou demonstrar que as mudanças ambientais como desmatamento, tipo de sucessão secundária e a conversão de florestas

\footnotetext{
${ }^{18}$ Para mais detalhes, ver Liverman et al (1998).
} 
em pastagens deveriam ser entendidas como produto da idade e da composição da família. Estes autores, com o intuito de comprovar suas hipóteses, combinam dados de sensoriamento remoto e de sistemas de informações geográficas com dados primários em nível de propriedade, na tentativa de analisar as estratégias de uso da terra no desenvolvimento da propriedade, dentro do ciclo de vida da família. Os autores ressaltam também que este tipo de metodologia possibilita a construção de uma variedade de estatísticas descritivas e espaciais em nível de propriedade. Porém, destacam ainda que as análises efetuadas no estudo são exploratórias.

Assim sendo, apesar de usarem o modelo teórico proposto por Walker \& Homma (1996), não utilizam em suas análises de regressão nenhuma variável demográfica, concentrado seus esforços no entendimento dos efeitos do tipo de solo, da acessibilidade ao mercado, do tempo de residência na propriedade, na percentagem da área total com pastagens, no tipo de sucessão secundária e na percentagem de área com florestas sobre o desmatamento.

Diferentemente dos estudos anteriores, seus resultados demonstraram que propriedades com semelhantes áreas com florestas e tipo de sucessão secundária possuíam maiores probabilidades de terem altas taxas de desmatamento à medida que se afastavam da cidade. Neste caso, argumentaram que, embora os resultados sejam preliminares, podem haver exceções no padrão geralmente encontrado na literatura. Em termos gerais, observou-se que o tempo de residência na propriedade e a percentagem da área com pastagens não eram significantes para explicar o desmatamento. Contudo, o tipo de solo é significante e positivamente relacionado ao desmatamento.

Observa-se, pelo exposto, que de uma maneira geral, a dinâmica de produção familiar evolui conjuntamente com os objetivos dos membros da família, bem como em decorrência de fatores institucionais de mercado e de recursos naturais. Neste contexto, o trabalho familiar inserido no mercado de trabalho local tem papel fundamental na tomada de decisão de uso da terra. Famílias com abundante mão-deobra, por exemplo, podem decidir por estratégias que usem intensivamente o fator 
trabalho, tais como o cultivo do cacau, café ou pimenta-do-reino, culturas tipicamente usadas na Amazônia. Por outro lado, famílias com poucos recurso de mão-de-obra podem optar por estratégias poupadoras desse fator como, por exemplo, o estabelecimento de pastagens ou cultivos anuais.

\subsection{Modelos empíricos utilizados em estudos de desmatamento}

A literatura apresenta diferentes modelos empíricos que foram utilizados nos estudos das causas direcionadoras do desmatamento. Em termos de aplicações, esses modelos têm sido utilizados em escalas global, nacional e regional. Contudo, os modelos estatísticos utilizados nesses estudos dependem das características da variável dependente utilizada e do número de equações inter-relacionadas que se procura estimar. Por exemplo, quando a variável dependente é expressa em termos de proporção da área total utilizada, modelos Logito e Probito são geralmente utilizados (Munoz, 1992; Thapa et al., 1996; Godoy et al., 1998).

Assim, seguindo esta linha de raciocínio, Thapa et al. (1996) analisaram se as formas de uso da terra, associadas ao desmatamento, afetavam a participação do trabalho feminino nas atividades agrícolas em áreas de colonização na Amazônia equatoriana. Esses autores notaram que as atividades de plantio e colheita consumiam significantes montantes de tempo e estavam relacionadas às estações mais ocupadas do ano. Dessa forma, definiram a variável dependente como sendo o envolvimento da mulher no plantio e na colheita, assumindo o valor 1 (um) se a mulher participava em ambas atividades e 0 (zero) caso contrário.

Por outro lado, as variáveis explanatórias foram baseadas nas características da familia (tamanho e composição), na área com culturas anuais e perenes, na área com pastagem, no trabalho fora da propriedade e nas características das mulheres (idade, nível de educação, experiências com atividades agrícolas, etc.). Com a definição de uma variável dependente binária, uma regressão logística foi, então, utilizada. Os resultados sugeriram que a forma com que a terra foi utilizada é um fator determinante do tipo de trabalho da mulher e não a quantidade de área total desmatada. 
Com relação a modelos Tobito, Godoy et al. (1997), por exemplo, analisaram as causas do desmatamento efetuado por índios em Honduras. Os autores mediram cada parcela de floresta primária, em hectares, em 1995, e atribuíram valor zero à variável área de floresta desmatada em 1995, que não tenha advindo de floresta primária. $\mathrm{Na}$ amostra utilizada, cerca de $51 \%$ das famílias não tinham efetuado nenhum desmatamento de floresta primária no ano em análise. Os resultados demonstraram que o nível de educação do chefe da família, o tempo de residência na área, a idade do chefe da família e a disponibilidade de crédito afetaram a área de floresta primária desmatada.

Pichón (1997), por sua vez, elaborou um estudo para a Amazônia equatoriana com base em um conjunto de regressões. Dada a inter-relação nas decisões de alocação, cada regressão representava uma parcela do tipo de uso da terra. Tal como no trabalho anterior, o autor utilizou modelos Tobito para estimar os coeficientes das regressões, uma vez que 26 famílias não tinham terra em floresta, 25 não plantavam nenhuma cultura perene, 46 não plantavam nenhuma cultura anual e 68 não tinham nenhuma área em pastagem.

Os resultados demonstraram que a fertilidade do solo tinha relação negativa com a parcela de área em floresta, ou seja, áreas com solos férteis tinham mais área desmatada. Por outro lado, áreas montanhosas possuíam mais áreas com florestas. O tempo de residência na área em estudo demonstrou relação negativa com a área com floresta, bem como com a disponibilidade de motosserra.

Contudo, o autor argumenta que nem sempre é possível diferenciar a degradação das áreas de floresta como conseqüência do empobrecimento do solo ou do tempo de residência. Em termos de influência de mercado na tomada de decisão de uso da terra, o autor usou como proxy a distância da área em estudo em relação à principal via de acesso, constatando que quanto maior a distância da principal rodovia de acesso, maior a área em floresta.

Vários outros autores utilizaram modelos de regressões usando a técnica de mínimos quadrados ordinários quando a variável dependente é contínua e expressa em 
termos de hectares desmatados (Godoy et al., 1997; Almeida \& Campari, 1995; Rudel \& Horowitz, 1993; Dehazo, 1993; Pichón \& Bilsborrow, 1992). Em geral, esses estudos demonstram que o regime de propriedade da terra, o tempo de residência na área e a composição da família têm importantes efeitos sobre a área total desmatada. Entre outros importantes fatores associados a áreas desmatadas estão também: qualidade do solo e localização do lote, sendo que melhores solos estão associados a maiores quantidades de áreas desmatadas, enquanto áreas situadas a grandes distâncias das cidades estão relacionadas a menor desmatamento.

No caso de modelos de desmatamentos que abordam aspectos em níveis globais, Allen \& Barnes (1985), por exemplo, analisaram as estimativas de desmatamento em países em desenvolvimento e suas prováveis causas. Três estimativas da taxa de desmatamento são comparadas com relação a três diferentes fontes. Dados de painel de 1968/78 são usados para estimar um modelo de regressão em que a mudança da área de floresta é função do crescimento populacional, da área agricultável, do crescimento do PNB e da produção de madeira. Os resultados da análise de painel confirmam que o desmatamento está significativamente relacionado ao crescimento populacional e à expansão da agricultura, sendo que países com alto crescimento populacional, rápida expansão agrícola e altos níveis de produção de madeira são os que apresentaram as maiores taxas médias de desmatamento ao longo do período 1968/78.

Diferentemente do estudo anterior, Rudel (1989) estudou as causas do desmatamento usando dados entre nações para o período de 1976/80, considerando apenas os países que possuíam florestas tropicais, através de uma ponderação da contribuição da área com floresta em cada país. Os resultados demonstraram que o crescimento populacional explica substancialmente as variações do desmatamento tropical, tal como anteriormente. Já alguns modelos, usualmente, ponderam o desmatamento por área total de floresta, tamanho da população ou renda nacional (Capistrano, 1990; Kahn \& McDonald, 1994). 
Outros estudos estatísticos sobre as causas do desmatamentos em níveis globais foram realizados por autores como Burguess (1993), Brown \& Pearce (1994) e Kant \& Redantz (1997). Contudo, os resultados encontrados por eles não diferem muito dos trabalhos anteriores.

A habilidade desses modelos em gerar conclusões quantitativas em termos globais, por exemplo, torna-os muito populares, principalmente pela dificuldade de coleta de dados em nível primário. Entretanto, a qualidade dos resultados não é das melhores, principalmente pela confiabilidade dos dados e pela dificuldade de homogeneizar os conceitos de desmatamento em diferentes países (Kummer \& Sham, 1994).

Por outro lado, os modelos de regressão com dados regionais têm sido focalizados em informações de municípios, estados, regiões ou países individuais. Neste caso, Lugo et al. (1981), estudando o desmatamento na área do Caribe, observaram que áreas com topografias íngrimes tinham maiores parcelas de florestas do que áreas com topografias mais planas, concluindo que a inacessibilidade a determinadas áreas diminui a suscetibilidade dessas áreas a serem desmatadas. Resultado que confirma certos estudos realizados em termos de propriedade.

Southgate et al. (1991), por sua vez, desenvolveram um modelo para desmatamento em áreas de fronteira no Equador dividido em duas equações. A primeira buscava descrever as forças demográficas responsáveis pelo desmatamento e a segunda procurava refletir o ambiente institucional que direcionava o desmatamento. Para o autor, o regime de propriedade prevalecente na região estimulava o desmatamento à medida que forçava a contínua exploração agrícola das parcelas para a solicitação do direito de posse.

Em termos de Amazônia brasileira, Reis \& Margullis (1991) elaboraram um modelo de desmatamento como função da densidade espacial das maiores atividades econômicas, usando uma forma funcional logarítmica. A equação básica do modelo relaciona frações de áreas desmatadas com as seguintes variáveis: densidade 
populacional, áreas com culturas, densidade de rodovias, distância da capital do estado, número de cabeças de gado, metros cúbicos de madeira e uma variável dummy para os estados utilizados. A estimativa usou dados "cross section" dos municípios da Amazônia. Apesar dos problemas de multicolinearidade, a estimativa dos parâmetros foi significativa no caso das variáveis população, lavouras, rodovias e, em menor escala, pecuária. No caso da variável metros cúbicos de madeira, o coeficiente não foi significativamente diferente de zero.

Em um segundo passo, os autores elaboraram outro conjunto de equações, com base em dados "cross section" de 1980 e 1985, para predizer os padrões espaciais do crescimento de cada uma das atividades econômicas. Essas equações relacionam o crescimento de uma atividade, por exemplo, conversão de floresta em culturas, à sua densidade em determinado ano. Os resultados mostram que o período se caracterizou por padrão de dispersão típico da expansão de áreas de fronteira, sendo que as taxas de crescimento são menores nas áreas de menor densidade de atividade. Cabe aqui frisar que poucos modelos, como os de Reis \& Margullis (1991), examinam a relativa importância do número de cabeças de gado, áreas com culturas anuais e perenes como fontes de desmatamento.

Por outro lado, quando se analisa o desmatamento ocorrido na Amazônia brasileira usando-se a combinação de dados de sensoriamento remoto com dados primários ou secundários, constata-se que pouquíssimos trabalhos utilizaram esta técnica. Dentre estes, destacam-se os trabalhos de Andersen (1996), Pfaff (1999), Wood \& Skole (1998), McCraken et al. (1999) e Walker et al. (2000).

Reis \& Guzmám (1992), por exemplo, usando dados "cross section" de municípios, estimaram um modelo econométrico para o desmatamento na Amazônia brasileira. Este modelo consiste de três blocos de equações: na primeira, a área desmatada é determinada pelas maiores atividades econômicas; na segunda, uma relação entre tipos de vegetação e biomassa determina as emissões de dióxido de carbono causadas pelo desmatamento; e na terceira equação, os autores procuram observar como 
a distribuição espacial da população e as maiores atividades econômicas tornam possível a simulação de padrões futuros de desmatamento.

Diferentemente do trabalho anterior, os autores levaram em consideração o fenômeno da autocorrelação espacial, permitindo melhores diagnóstico e tratamento dos problemas resultantes da omissão de variáveis, erros de medida e imprópria especificação do modelo. Dados de desmatamento foram derivados de imagens de satélite Landsat. Os autores usaram mínimos quadrados ordinários e estimativa por máxima verossimilhança na estimativa de seus resultados. Em geral, estes autores mostram que a criação de gado, a agricultura e o tamanho da população rural foram as mais importantes fontes do desmatamento.

Também utilizando dados georreferenciados, Andersen \& Reis (1997) desenvolveram um modelo econométrico para a Amazônia brasileira com base em dois setores, um rural e outro urbano. Os autores assumem que o setor urbano não causa o desmatamento diretamente devido às atividades urbanas que requerem pequena porções de terra. Todavia, os autores argumentam que existe um efeito indireto por demanda de produtos agrícolas.

O modelo consiste em seis equações. A principal prediz a demanda por novos desmatamentos em determinadas região e tempo, com base nas características passadas da região e de sua vizinhança. As outras cinco explicam a interação entre populações urbana e rural, produtos urbano e rural e preço da terra. As seis equações foram assumidas como log-lineares. A utilização de dados georreferenciados permitiu testes de autocorrelação espacial. Os resultados demonstram que o desmatamento é quase exclusivamente determinado pela demanda por novas áreas agrícolas que, por sua vez, depende da lucratividade da terra.

No caso do trabalho de Andersen (1996), o artigo analisa os determinantes do desmatamento usando dados para 316 municípios durante o período de 1975 a 1985 . Duas medidas de desmatamento foram utilizadas baseadas em dados de imagens de satélite e em dados de Censo. A autora descobriu que as duas medidas de desmatamento 
são consistentes uma com a outra, porém são medidas conservadoras quando comparadas com outros estudos e que as forças econômicas locais são mais importante do que as políticas federais de desenvolvimento. Para a autora, o governo federal certamente iniciou o processo de desmatamento através da construção de estradas e programas de desenvolvimento, mais perdeu o controle para as forças locais de mercado.

Pfaff (1999), por sua vez, estima os determinantes do desmatamento na Amazônia brasileira através de um modelo de uso da terra baseado na alocação ótima dos recursos. Nesta análise, os dados de desmatamento foram medidos através de imagens de satélite, para o período de 1978 a 1988, também em nível de município, combinando-os com dados de censos. Os resultados desta análise demonstram que: se a densidade populacional for a única variável independente, então, esta será significante na determinação do desmatamento.

Todavia, a inclusão de outras variáveis sugere que seu coeficiente estava captando boa parte dos efeitos de outras variáveis omitidas; o aumento no número de estradas em um município influenciava diretamente o aumento da área desmatada no município em questão, assim como, nos municípios vizinhos; que os projetos de desenvolvimento elaborados pelo governo federal estavam mais diretamente associados com o desmatamento nos anos 70 , mais não nos anos 80 ; que quanto maior a distância da Amazônia para os mercados do Sul do país, menor era o desmatamento; que a qualidade do solo estava positivamente relacionada à área desmatada; e que a provisão de crédito por agência pelo governo federal demonstrou-se insignificante na análise de regressão. Para o autor, este resultado podia ser devido à pobre qualidade dos dados de crédito. Em outras palavras, dado que havia sinais de colinearidade entre crédito por agência e população, toda vez que se retirava a variável população da equação de regressão, o coeficiente da variável crédito aumentava, tornando-a significante. Para o autor, as regras de decisões de alocação de agências podia ter como base a abertura de agências onde havia contingente populacional em condições de obtê-lo, isto é, município com suficiente população. 
Já Wood \& Skole (1998), por outro lado, usam dados de sensoriamento remoto combinados com dados de Sistemas de Informações Geográficas, por município, bem como de censos para modelar os determinantes demográficos e econômicos do desmatamento. Por meio do método dos mínimos quadrados ordinários, os autores estimaram vários modelos em que a variável dependente área desmatada por quilômetro quadrado em cada município é função do tamanho da população local e da que migrou para a região, das atividades em que as pessoas estão engajadas e do tamanho do estabelecimento rural.

Testes de autocorrelação espacial foram efetuados para detectar problemas de omissão de variáveis, mal-especificação do modelo, erros de medida e, pelo fato de os autores utilizarem dados georreferenciados, na tentativa de verificar potenciais influências de efeitos espaciais nos resultados das regressões. Estes autores confirmam que a composição da força de trabalho, o tamanho da população migratória, bem como o tamanho do estabelecimento rural, são importantes determinantes do desmatamento.

Considerando-se apenas trabalhos que abordam a combinação de sensoriamento remoto com dados primários, apenas McCraken et al. (1999) e Walker et al. (2000) utilizaram esta metodologia. Walker et al. (2000), por exemplo, utilizando imagens de satélite (TM) para o ano de 1991, procuram decompor o desmatamento na Amazônia brasileira entre os produzidos pelos pequenos produtores e os produzidos pelos fazendeiros de gado, em quatro regiões no estado do Pará. Com base em uma amostra de 132 pequenos produtores, extrai uma subamostra de 32 produtores, e compara o desmatamento produzido, relatado pelos produtores, com os medidos pelas imagens.

Diferentemente do trabalho proposto aqui, os autores não utilizaram um mapa das propriedades. Pelo contrário, a partir de inspeção visual, utilizaram a hipótese de haver um padrão de desmatamento. Ou seja, mediram todas as áreas desmatadas, grandes e pequenas que apresentaram um determinado padrão retangular, sugestivo de propriedades. Para os autores, este tipo de mensuração provavelmente representa um 
limite inferior do desmatamento pertencendo a cada classe (isto é, fazendeiros e pequenos produtores).

Testes de autocorrelação espacial não constataram problemas de omissão de variáveis. Sendo assim, métodos de mínimos quadrados ordinários foram utilizados. Os resultados demonstraram que para áreas onde houve substancial migração de pequenos produtores, o desmatamento produzido em nível de familia é principalmente atribuível à disponibilidade de trabalho contratado e não em função da força de trabalho familiar ou do capital físico à disposição da família. Os autores destacam uma substancial discrepância entre as medidas de desmatamento adotadas onde os pequenos produtores foram conservadores nas respostas da área total desmatada. 


\section{METODOLOGIA}

Neste capítulo, apresentam-se a forma funcional empregada na presente pesquisa, as variáveis utilizadas e os possíveis problemas que podem surgir em decorrência da omissão de variáveis e da utilização de dados georreferenciados. Finalmente, testes de autocorrelação espacial são apresentados, juntamente com os procedimentos econométricos utilizados.

\subsection{A especificação do modelo econométrico proposto}

Nos últimos anos, grandes esforços foram efetuados na tentativa de modelar os determinantes do desmatamento. Todavia, modelos quantitativos possuem muitas limitações, uma vez que se centram em variáveis sobre as quais dados quantificáveis estão disponíveis. Por exemplo: falhas de mercado quase nunca são abordadas nos modelos empíricos, exatamente pela dificuldade de se medir o valor econômico de preservar uma floresta. Além deste, fatores institucionais (como crédito e titulação) também são raramente incluídos.

Para alguns autores, como Andersen (1996), não existe uma teoria aceitável sobre desmatamento que defina as variáveis explanatórias que deveriam ser incluídas em um modelo empírico. Para Pichón (1993), a literatura sobre desmatamento na Amazônia, em âmbito familiar, não oferece nenhum guia sobre a apropriada forma funcional a ser utilizada na análise dos fatores direcionadores do desmatamento.

Dessa forma, buscando-se preencher um espaço na literatura, Walker et al. (2000) já apresentam direcionamentos a serem seguidos. Estes autores baseiam suas análises na abordagem estabelecida por Turner et al. (1994), onde o desmatamento pode 
ser explicado através da divisão entre as forças direcionadoras e das causas imediatas do desmatamento. Ou seja, argumentam que as mudanças na cobertura vegetal ocorrem em decorrência das respostas a fatores internos e externos às unidades de produção (ou seja, as famílias) que, por sua vez, levam a alterações na escolha dos sistemas agrícolas. Todavia, como ressaltado anteriormente, estes autores baseiam-se em noções intuitivas. Neste contexto, busca-se testar empiricamente algumas variáveis que reflitam as causas do desmatamento, através da interação entre o modelo de Chayanov e o modelo neoclássico, utilizando-se para isto análises de regressões.

Matematicamente, um modelo empírico de desmatamento pode ser postulado, de forma bem simples, como representante de uma relação linearizável dos parâmetros entre a variável dependente $\mathbf{Y}$ e cada uma das variáveis independentes, tal que:

$$
\mathbf{Y}=\mathbf{X} \boldsymbol{\beta}+\varepsilon
$$

onde $\mathbf{Y}$ é a uma matriz representando os valores da variável dependente; $\mathbf{X}$, o conjunto de variáveis explanatórias; $\beta$ são os coeficientes da regressão e $\varepsilon$ é o termo de erro aleatório.

Desta forma, uma especificação inicial do modelo, com base nas considerações teóricas e na disponibilidade de dados, pode ser estabelecida da seguinte maneira: Y é a magnitude do fator produtivo terra (ou a área total desmatada), tal que a primeira derivada, $d Y / d t$, representa o crescimento do tamanho da área usada em cada lote por período de tempo, ou seja, o desmatamento. Assim sendo, uma equação diferencial pode ser escrita como:

$$
d Y / d t=f(X)
$$

onde $X$ é um vetor das forças determinantes do desmatamento. Esta expressão pode ser estabelecida em termos de equação em diferença para análise de regressão como: 


$$
\Delta Y=f(X)
$$

com $X=[Y, F, D, R, I D, T, D I, I, D P]$, onde $Y$ é o tamanho da área utilizada em cada lote (calculado através de sensoriamento remoto, em hectares); $F$ reflete a mão-de-obra da família (força de trabalho, em números de homens, mulheres, crianças e idosos); $D$ é a distância do mercado (em quilômetros); $R$ representa o nível de riqueza da família; $I D$ é a idade do chefe da família (medida em anos); $T$ é o tempo de residência na propriedade (medido em anos); e DI é o total de mão-de-obra contratada (em dias/homens), I reflete a ação dos fatores institucionais na propriedade (por exemplo, crédito e título), e $D P$ é a dependência. Conseqüentemente, a seguinte função pode ser estabelecida:

$$
\Delta Y_{t}=f\left(Y_{t-1}, F_{t}, D, R_{t}, I D_{t}, T_{t}, D I_{t}, I_{t}, D P\right)
$$

com $\Delta Y$, representando a magnitude do desmatamento em determinado ano $t$.

\subsection{Definição das variáveis}

Com a finalidade de testar empiricamente os efeitos pressupostos, apresentam-se a seguir as variáveis usadas na presente pesquisa. Ressalta-se em princípio que neste estudo se considera apenas as famílias nucleares. Isto significa que parceiros e meeiros não são contabilizados no número total de membros na família.

\section{Variável Dependente:}

\section{Área Total Desmatada (Y)}

Representa a área total desmatada na propriedade. Ou seja, é o somatório de todas as áreas desmatadas, em hectares, em cada lote que a família possuía em 1996, medido através de imagens de satélite para o ano de 1997. 


\section{Variáveis Independentes:}

\section{Idade do Chefe da Família (ID)}

Representa a idade do chefe da família, em anos, na data da coleta dos dados. Dado que com o passar dos anos o chefe da familia perde vigor fisíco, espera-se que com o passar dos anos, a área desmatada diminua.

\section{Tempo de Residência na Propriedade (T)}

Variável que representa o tempo total de residência na propriedade, medida em anos, até a data da coleta de dados. Dado que a amostra cobre desde produtores antigos até produtores recém estabelecidos e, uma vez que lotes estabelecidos mais cedo podem possuir maiores parcelas desmatadas, espera-se uma associação positiva entre o tempo de residência e a área total desmatada.

\section{Trabalho Contratado (DI)}

Variável que mede o número total de diárias pagas, em homens dias, no ano anterior à coleta de dados. Espera-se uma relação positiva entre o número total de diárias e a área total desmatada.

\section{Acessibilidade ao Mercado (D)}

Esta variável mede a influência da força do mercado no processo de desmatamento. É pressuposto que a acessibilidade ao mercado influencia positivamente a área total desmatada. Neste contexto, considera-se como principal via de acesso ao mercado a rodovia Transamazônica e usa-se a distância do lote para a rodovia como uma "proxy" da acessibilidade e da influência do mercado. Ou seja, quanto menor a distância entre o lote e a rodovia, em quilômetros, maior a área total desmatada. Cabe aqui ressaltar que, dado que algumas famílias já possuem mais de um lote, optou-se por considerar somente a distância existente entre o primeiro lote adquirido, na 
pressuposição de que este seja o principal lote da família. Esta variável foi obtida através da pesquisa de campo em 1996.

\section{Tamanho da Família (F)}

Esta variável representa o número total de membros na família (homens, mulheres, crianças e idosos). Espera-se, de acordo com o modelo conceitual proposto, que quanto maior o tamanho da família, maior a área total desmatada. Isto é, a existência de uma associação positiva entre o total de membros na família e a área total desmatada.

\section{Dependência (DP)}

Variável que mede a relação entre o número de trabalhadores e de consumidores na família. Ou seja, é o somatório do número de crianças mais idosos dividido pelo tamanho da família. De acordo com o modelo conceitual proposto, esperase que quanto maior a relação de dependência, menor é a disponibilidade de mão-deobra e, por conseguinte, menor a área desmatada na propriedade.

\section{Total de Homens Adultos na Família (F_homens)}

Variável que identifica o número total de homens entre 15 e 65 anos na família. Espera-se, de acordo com o modelo conceitual proposto, que quanto maior o número total de homens na família, maior a oferta de mão-de-obra e, conseqüentemente, maior o desmatamento.

\section{Total de Mulheres Adultas (F_mulheres)}

Variável que identifica o número total de mulheres entre 15 e 65 anos (exclusive), na família. Espera-se que quanto maior o número de mulheres na família, menor o índice de dependência, e conseqüentemente maior, o desmatamento. 


\section{Total de Crianças na Família (F_crianças)}

Variável que mede o número total de crianças entre 0 e 14 anos na familia. Espera-se que exista um relacionamento positivo entre o total de crianças na família e a área total desmatada. Ou seja, quanto maior o número de crianças na família, maior o índice de dependência, e, conseqüentemente, menor é a disponibilidade de mão-de-obra, logo, menor o desmatamento.

\section{Total de Idosos na Família (F_idosos)}

Variável que identifica o número total de idosos acima de 65 anos na família. Espera-se que quanto maior o número de idosos na família, maior o indíce de dependência, e em conseqüência, menor a área total desmatada na propriedade.

\section{Crédito Agrícola (I_C_propriedade)}

Variável "dummy" que mede o acesso ao crédito pelas famílias. Atribui-se o valor 1 para as famílias que tiveram acesso ao crédito em pelo menos um dos lotes e 0 em caso contrário. Espera-se que quanto maior o acesso ao crédito, maior a área total desmatada na propriedade.

\section{Título de Propriedade (I_T_propriedade)}

Variável "dummy" que mede a acessibilidade à propriedade da terra. Atribui-se o valor 1 para as famílias que possuem o título de propriedade (definitivo ou provisório) em pelo menos um dos lotes e 0 em caso contrário. Espera-se que as famílias que possuam o título de propriedade desmatem menos, uma vez que não necessitariam desmatar para assegurar a posse da terra.

\section{Nível de Riqueza Inicial 1 (R_1)}

Variável "dummy" que mede o nível de riqueza da família na chegada ao assentamento. Assume o valor 1 se a família possuía fogão a gás ou motosserra na época 
do assentamento no lote e 0 em caso contrário. É pressuposto que quanto maior o nível de riqueza inicial da família, maior a área total desmatada.

\section{Nível de Riqueza Inicial 2 (R_2)}

Variável "dummy" que mede o nível de riqueza da família na chegada ao assentamento. Assume o valor 1 se a família possuía geladeira, gerador, televisão, antena parabólica ou motocicleta, 0 em caso contrário. É pressuposto que quanto maior o nível de riqueza inicial da família, maior a área total desmatada.

\section{Nível de Riqueza Inicial 3 (R_3)}

Variável "dummy" que mede o nível de riqueza da família na chegada ao assentamento. Assume o valor 1 se a família possuía carro ou trator, 0 em caso contrário. Espera-se que quanto maior o nível de riqueza inicial da família, maior a área desmatada.

\subsection{Modelos econométricos para a correção de problemas de autocorrelação espacial}

A principal contribuição dos modelos de regressão está centrada na identificação das variáveis fortemente associadas ao desmatamento, assumidas como as principais forças que influenciam o desmatamento. Contudo, deve-se ter cuidado ao extrapolar os resultados no espaço ou no tempo, pois é muito possível que um modelo que se ajuste bem a determinada região não reproduza os mesmos resultados em outra. Da mesma forma, enquanto os modelos de regressão podem tratar adequadamente a dimensão tempo do processo que representam, são intrinsecamente não-espaciais, ou seja, não consideram a distribuição espacial dos elementos em uma área e os efeitos adjacentes.

Isto quer dizer que as análises "cross section" em níveis regional ou nacional são baseadas na hipótese não-realista de que o desmatamento em dada unidade administrativa é preliminarmente função de fatores daquela região. Conseqüentemente, 
quando se utilizam, em modelos de regressão, dados advindos de coordenadas geográficas, deve-se considerar a possibilidade da influência de efeitos espaciais.

A autocorrelação espacial, ou mais genericamente a dependência espacial, pode ser definida como a situação onde a variável dependente ou o termo de erro a cada localidade está correlacionado com as observações da variável dependente, ou com os valores do termo de erro em outras localidades. Estes são conhecidos na literatura como autocorrelação ou heterogeneidade espacial, sendo que a não-consideração desses efeitos espaciais pode levar a estimativas inconsistentes dos coeficientes da regressão (Anselin, 1988). Em termos gerais pode-se formalmente definir a autocorrelação espacial como:

$$
\begin{aligned}
& E\left(y_{i} y_{1}\right) \neq 0, \quad i \neq j \\
& \mathrm{Ou} \\
& E\left(\varepsilon_{i}, \varepsilon_{j}\right) \neq 0, \quad i \neq j
\end{aligned}
$$

para vizinhanças i e j. Contudo, este tipo de especificação é muito genérico para permitir a estimação de $N$ vezes $(N-1)$ interações das $N$ observações. Dessa forma, é dada à dependência espacial uma estrutura por meio de uma matriz de ponderação espacial (W) que reduz o número de parâmetros desconhecidos a 1 (um), isto é, ao coeficiente da associação espacial num processo espacial auto-regressivo.

A dependência espacial ou autocorrelação espacial pode dar-se de duas formas. Na primeira, afeta somente os termos de erro e é, na maioria das vezes, considerada uma perturbação que precisa ser eliminada (King, 1987; Anselin, 1988). Como no caso geral de erros não-correlacionados, a autocorrelação espacial dos resíduos não produz estimativas de mínimos quadrados ordinários viesadas, mas altera sua eficiência. Conseqüentemente, a interpretação do nível de significância, que é baseada em testes " $t$ " e $R^{2}$, é viesada (Anselin \& Rey, 1991; Griffith, 1988). 
$\mathrm{Na}$ segunda forma, é dada à dependência espacial uma interpretação substantiva, em que a variável de interesse em certa localização é determinada por seus valores em outras. Por exemplo, a área desmatada em uma determinada propriedade para o plantio de cacau pode ter recebido influência de áreas desmatadas em outras localidades vizinhas, que também plantaram cacau. Assim, um modelo corretamente especificado deveria incluir um termo espacial auto-regressivo, isto é, uma soma ponderada dos valores da variável dependente em outras localizações; é a conhecida variável dependente espacialmente defasada (Anselin \& Rey, 1991).

Desta forma, uma importante questão em análise empírica está centrada na detecção destes efeitos espaciais e, além disto, em como diferenciar a autocorrelação espacial decorrente de uma perturbação nos erros de uma interpretação substantiva (Doreian, 1980; Anselin \& Griffith, 1988).

Assim sendo, um modelo auto-regressivo para termos de erros pode ser formalmente especificado como:

$$
\begin{aligned}
& \mathbf{Y}=\boldsymbol{\beta} \mathbf{X}+\boldsymbol{\varepsilon} \\
& \boldsymbol{\varepsilon}=\lambda \mathbf{W} \boldsymbol{\varepsilon}+\boldsymbol{\mu}
\end{aligned}
$$

onde $\mathrm{Y}$ é um vetor $N \times 1$ de observações da variável dependente; $\mathrm{X}$, uma matrix $N$ x $K$ de variáveis independentes ou exploratórias; $\beta$, um vetor de coeficientes $K \times 1$; e $\varepsilon$, um vetor de erros $N \times 1$, assumindo-se serem normalmente distribuídos, mas autocorrelacionados; $\lambda$ sendo o coeficiente auto-regressivo espacial (que mede a intensidade do fenômeno da autocorrelação espacial); W, uma matrix de influência espacial $N \times N$; e $\mu$, o termo de erro assumido como normalmente distribuído $-\boldsymbol{\mu} \sim N\left(0, \sigma^{2} I\right)$. Neste caso, pode-se definir a hipótese nula da seguinte forma:

$$
H_{0}: \lambda=0
$$

ou seja, o termo de erro é não-correlacionado. 
A matrix de influência espacial $\mathbf{W}$ expressa, por sua vez, o poder da interação entre cada observação com as observações adjacentes, ou seja, a estrutura dos dados em termos de espaço. Essa matrix pode ser baseada em um coeficiente de contigüidade binária simples $\left(w_{i j}=1\right)$ se $i$ e $j$ têm fronteira comum, e $\left(w_{i j}=0\right)$ em caso contrário. Por convenção, os elementos da diagonal principal dessa matriz são zero, isto é, nenhuma observação é vizinha dela mesma ${ }^{19}$.

Os modelos de autocorrelação espacial freqüentemente resultam quando variáveis geográficas importantes não são especificadas, tais como qualidade do solo e tipo de vegetação que operam em grande escala, mais do que em micro (por exemplo, lotes). Desta forma, a correlação espacial, nos resíduos de uma regressão, pode refletir a omissão de variáveis, uma mal especificação do modelo ou erros de medida dos dados utilizados (Reis \& Guzmán, 1992).

A segunda forma de autocorrelação espacial é conhecida como modelo autoregressivo de defasagem espacial misto, em que uma defasagem espacial, WY, para a variável dependente é introduzida no modelo de regressão como variável explanatória adicional. Neste caso, esse modelo é similar a um termo auto-regressivo em análises de séries temporais ${ }^{20}$, muito embora haja várias importantes diferenças que requerem metodologia especializada para estimativa e teste. Formalmente, esse modelo é expresso como:

$$
\mathbf{Y}=\rho \mathbf{W} \mathbf{Y}+\boldsymbol{\beta} \mathbf{X}+\boldsymbol{\mu}
$$

onde $\rho$ é o coeficiente espacial auto-regressivo; e $\mu$ um vetor $N \times 1$ com erros normalmente distribuídos, com as outras notações permanecendo como antes. Neste caso, a hipótese nula da ausência de autocorrelação corresponde a:

\footnotetext{
${ }^{19}$ Em análises de regressão, a matriz w é tipicamente normalizada, isto é, cada elemento da matriz de contiguidade original tem sido dividido pela soma da linha a que pertence, de modo que, na matriz normalizada, a soma de cada linha é igual a 1.

${ }^{20}$ Apesar de a autocorrelação espacial ser, de certa forma, análoga ao problema de correlação serial na análise de séries temporais, a maior complexidade está na direção da influência, já que, na autocorrelação espacial, as variáveis podem influenciar em todas as direções.
} 


$$
H_{0}: \rho=0
$$

A impropriedade dos estimadores de mínimos quadrados para modelos que incorporam dependência espacial tem focalizado a atenção na abordagem da Máxima Verossimilhança como alternativa (Ord, 1975; Anselin, 1988). Neste caso, pode-se adaptar um procedimento interativo desenvolvido primeiramente por Cochrane \& Orcutt (1949) em modelos de séries temporais, para o caso de correlações espaciais. Desta forma, para cada modelo, os coeficientes auto-regressivos são obtidos com estimativa por máxima verossimilhança. O procedimento adaptado de Cochrane \& Orcutt consiste em três passos: em primeiro lugar, os estimadores de mínimos quadrados ordinários são calculados; os resíduos são, então, utilizados para obter uma estimativa para os coeficientes $\lambda$ e $\rho$ de autocorrelação espacial; e finalmente, esses coeficientes são substituídos no procedimento de estimativa de máxima verossimilhança.

\subsection{Testes de autocorrelação espacial}

\subsubsection{Teste de Moran I}

Uma importante questão na análise espacial empírica está centrada na identificação da presença desses efeitos espaciais, ou seja, como distinguir entre a dependência espacial decorrente de um distúrbio e aquela decorrente da influência de uma interpretação substantiva.

Um teste bem conhecido para autocorrelação espacial em termos de erros da regressão foi desenvolvido por Cliff \& Ord (1972). Este tem base na generalização da estatística de Moran I para os resíduos da regressão. Neste caso, a estatística de Moran I para a autocorrelação espacial pode ser aplicada utilizando os resíduos da regressão de forma direta. Formalmente, tem-se:

$$
I=(N / S) \mathbf{e}^{\prime} \mathbf{W} \mathbf{e} / \mathbf{e}^{\prime} \mathbf{e}
$$


onde e é o vetor de resíduos dos mínimos quadrados ordinários; $\mathbf{W}$, uma matriz de influência espacial; $N$, o número de observações; e $S$, um fator de estandardização igual à soma de todos os elementos da matriz W. A interpretação desse teste não é tão direta como sua aplicação, muito embora seja o mais utilizado na literatura (Anselin \& Rey, 1991). Neste caso, a hipótese nula avalia a presença da dependência espacial e uma expressão precisa para a hipótese alternativa não existe (Anselin \& Rey, 1991). A inferência é baseada no estandardizado valor de $z$, que segue uma distribuição normal (assintoticamente). Intuitivamente, a matriz $\mathbf{W}$ representa o padrão espacial que causa a dependência, mas a natureza do processo estocástico não é especificada. Usualmente, assume-se ser da forma espacial auto-regressiva. O software SpaceStat reporta o valor da estatística de Moran I, o correspondente valor de $z$ e a probabilidade associada de acordo com a distribuição normal padrão. Entretanto, segundo Anselin \& Rey (1991), o teste de Moran I apenas indica a presença da autocorrelação, ou não. Para estes autores, faz-se necessária a distinção entre os dois tipos de autocorrelação espacial, os quais podem ser detectados pelo teste dos multiplicadores de Lagrange.

\subsubsection{Testes dos multiplicadores de Lagrange}

Os testes dos multiplicadores de Lagrange para dependência espacial situamse no domínio da máxima verossimilhança. Têm base nos teoremas de limite central para séries dependentes que podem ser aplicados ao processo espacial. Esses testes são assintoticamente distribuídos a $\chi^{2}$ e com 1 (um) grau de liberdade (Anselin \& Rey, 1991). Assim, o teste de autocorrelação espacial do termo de erro pode ser calculado aplicando-se a seguinte fórmula:

$$
M L_{e r r}=\left[N \mathbf{e}^{\prime} \mathbf{W e} / \mathbf{e}^{\prime} \mathbf{e}\right]^{2}\left[t r\left(\mathbf{W}^{\prime} \mathbf{W}+\mathbf{W}^{2}\right)\right]^{-1}
$$

onde $t r$ representa o traço da matriz, com os outros símbolos permanecendo como antes.

No caso do teste dos multiplicadores de Lagrange para a variável dependente espacialmente defasada, este pode ser aplicado utilizando-se a seguinte fórmula: 


$$
M L_{l a g}=\left[N \mathbf{e}^{\prime} \mathbf{W} \mathbf{Y} / \mathbf{e}^{\prime} \mathbf{e}\right]^{2}\left[N(\mathbf{W X} b)^{\prime} \mathbf{M}(\mathbf{W X} b) / \mathbf{e}^{\prime} \mathbf{e}+\operatorname{tr}\left(\mathbf{W}^{\prime} \mathbf{W}+\mathbf{W}^{2}\right)\right]^{-1}
$$

onde $b$ representa a estimativa de mínimos quadrados ordinários para $\mathbf{B}$, e $\mathbf{M}$ é uma matriz idempotente. Para Anselin \& Rey (1991), não há uma exata distribuição das estatísticas dos multiplicadores de Lagrange.

Segundo Anselin \& Rey (1991), um atrativo de ambos os testes tem por base a utilização das estimativas obtidas pelo cálculo dos mínimos quadrados ordinários.

\subsection{Procedimentos econométricos}

São três as etapas dos procedimentos econométricos utilizados no presente trabalho. A primeira consiste em calcular os estimadores de mínimos quadrados ordinários. Na segunda etapa, utilizam-se os resíduos da regressão para fazer os testes de autocorrelação espacial; e finalmente, uma vez aceita a hipótese de que existe autocorrelação espacial, utiliza-se o procedimento de máxima verossimilhança para a estimativa do modelo apropriado. 


\section{RESULTADOS E DISCUSSÃO}

O objetivo desta seção é apresentar uma visão geral das características sociodemográficas da população, dos fatores institucionais e de mercado, e da área em estudo, com suas respectivas implicações no uso da terra. Cabe aqui frisar que as análises apresentadas são de caráter exploratório, uma vez que se baseiam em análises descritivas bivariadas.

\subsection{Características gerais da população amostrada}

Observa-se primeiramente na Tabela 1 que os dados obtidos da subamostra não são diferentes, em termos estatísticos, da amostra original levantada em campo. A única diferença em termos de média ocorre para a variável distância. Na amostra original, a média em quilômetros do lote para a rodovia Transamazônica é superior à média da amostra digitalizada. Tal diferença é explicada por alguns colonos estarem assentados em lotes tão distantes da rodovia Transamazônica que seus lotes não constavam no mapa original cedido pelo Incra. Todavia, cabe aqui ressaltar que a maioria dos colonos que se encontrava nesta situação não possuía título de posse As médias das outras variáveis analisadas são também similares às coletas no levantamento de campo.. 
Tabela 1. Comparação entre as médias da amostra original e da amostra digitalizada para o Projeto de Colonização de Uruará/PA, 1996.

\begin{tabular}{|c|c|c|c|c|c|c|}
\hline \multirow{3}{*}{ Características } & \multicolumn{3}{|c|}{ Amostra Original } & \multicolumn{3}{|c|}{ Amostra Digitalizada } \\
\hline & & & & & & \\
\hline & $N$ & Média & $\begin{array}{l}\text { Desvio } \\
\text { Padrão }\end{array}$ & $\mathrm{N}$ & Média & $\begin{array}{l}\text { Desvio } \\
\text { Padrão }\end{array}$ \\
\hline Tamanho da Família & 259 & 7,51 & 7,77 & 161 & 7,21 & 4,84 \\
\hline No. De Homens (15 - 65 anos) & 258 & 2,35 & 1,63 & 160 & 2,39 & 1,60 \\
\hline No. De Mulheres (15-65 anos) & 258 & 1,75 & 1,22 & 160 & 1,76 & 1,20 \\
\hline No. De Crianças ( $0-14$ anos) & 258 & 2,85 & 2,74 & 160 & 2,85 & 2,86 \\
\hline No. De Idosos ( $>65$ anos) & 258 & 0,17 & 0,49 & 160 & 0,19 & 0,55 \\
\hline Idade do Chefe de família (anos) & 260 & 47,23 & 13,04 & 162 & 48,83 & 13,16 \\
\hline Tempo de Residência (anos) & 260 & 12,05 & 6,78 & 162 & 13,20 & 7,02 \\
\hline Instrução Formal (anos) & 248 & 2,03 & 2,16 & 154 & 2,01 & 2,14 \\
\hline Distância da Rodovia (km) & 261 & 17,08 & 14,49 & 163 & 14,18 & 11,88 \\
\hline
\end{tabular}

Fonte: Dados da pesquisa.

$\mathrm{N}$ : tamanho da amostra.

Observa-se que os colonos entrevistados na região são originários de várias partes do Brasil: $62 \%$ são da região Nordeste, $34,06 \%$ das regiões Sul e Sudeste, e os outros $3,85 \%$ de outras regiões do país, sendo que a região Nordeste foi a região que teve a mais forte migração para esta parte da rodovia Transamazônica (Tabela 2).

Tabela 2. Projeto de Colonização de Uruará/PA: número e porcentagem dos proprietários segundo região de origem do chefe de família, 1996.

\begin{tabular}{lcc} 
& \multicolumn{3}{c}{ Amostra } \\
\cline { 2 - 3 } & $\mathrm{N}$ & $\%$ do total \\
\hline Região Norte & 2 & 1,24 \\
Região Nordeste & 99 & 61,49 \\
Região Centro-Oeste & 5 & 3,10 \\
Região Sudeste & 25 & 15,53 \\
Região Sul & 30 & 18,64 \\
\hline Total & 161 & 100,00 \\
\hline
\end{tabular}

Fonte: Dados da pesquisa.

$\mathrm{N}$ : tamanho da amostra.

Casos não-declarados: 2. 
Dentre os estados da região Nordeste, Bahia e Ceará tiveram as maiores participações com 19,23\% e 18,68\% da migração, respectivamente. Por outro lado, os estados do Paraná e Minas Gerais são os maiores contribuintes das regiões Sul e Sudeste, com 9,89\% e 8,24\%, respectivamente. Porém, a participação destes estados é a metade das contribuições dos estados da Bahia e Ceará (Tabela 3).

A maioria dos colonos, antes da chegada à região, teve um período de residência em outros estados diferentes de suas regiões de origem. Por exemplo, apesar de apenas 9,89\% dos entrevistados terem nascido no Paraná, cerca de $20 \%$ dos colonos migraram daquele estado. No caso do Nordeste, aproximadamente $20 \%$ dos chefes de família entrevistados migraram do Maranhão, mas somente $9 \%$ nasceram lá (Tabelas 3 e 4).

Tabela 3. Estado de origem do chefe de família no Projeto de Colonização de Uruará/PA, 1996.

\begin{tabular}{|c|c|c|c|c|c|c|}
\hline \multirow{2}{*}{ Estados } & \multicolumn{2}{|c|}{ Amostra } & \multicolumn{2}{|c|}{ Rural } & \multicolumn{2}{|c|}{ Urbana } \\
\hline & $\mathrm{N}$ & $\%$ & $\mathrm{~N}$ & $\%$ & $\mathrm{~N}$ & $\%$ \\
\hline Bahia & 30 & 18,63 & 26 & 16,15 & 4 & 2,48 \\
\hline Ceará & 30 & 18,63 & 26 & 16,15 & 4 & 2,48 \\
\hline Paraná & 16 & 9,94 & 14 & 8,70 & 2 & 1,24 \\
\hline Maranhão & 15 & 9,32 & 14 & 8,70 & 1 & 0,62 \\
\hline Piauí & 15 & 9,32 & 13 & 8,70 & 2 & 1,24 \\
\hline Minas Gerais & 14 & 8,70 & 14 & 8,70 & - & - \\
\hline Outros & 41 & 25,46 & 35 & 21,10 & 6 & 3,74 \\
\hline Total & 161 & 100.0 & 142 & 88,20 & 19 & 11,80 \\
\hline
\end{tabular}

Fonte: Dados da pesquisa.

$\mathrm{N}$ : tamanho da amostra.

Casos não-declarados: 2. 
Tabela 4. Estados de residência anterior à migração para o Projeto de Colonização de Uruará/PA, 1996.

\begin{tabular}{|c|c|c|c|c|c|c|}
\hline \multirow{2}{*}{ Estados } & \multicolumn{2}{|c|}{ Amostra } & \multicolumn{2}{|c|}{ Rural } & \multicolumn{2}{|c|}{ Urbana } \\
\hline & $\mathrm{N}$ & $\%$ & $\mathrm{~N}$ & $\%$ & $\mathrm{~N}$ & $\%$ \\
\hline Maranhão & 33 & 20,50 & 28 & 17,39 & 5 & 2,48 \\
\hline Paraná & 30 & 18,63 & 29 & 18,01 & 1 & 2,48 \\
\hline Bahia & 22 & 13,66 & 19 & 11,80 & 3 & 1,24 \\
\hline Ceará & 20 & 12,42 & 18 & 11,18 & 2 & 0,62 \\
\hline Santa Catarina & 8 & 4,97 & 8 & 4,97 & - & 1,24 \\
\hline Outros & 48 & 29,82 & 40 & 24,85 & 8 & - \\
\hline Total & 161 & 100,0 & 142 & 88,20 & 19 & 3,74 \\
\hline
\end{tabular}

Fonte: Dados da pesquisa.

$\mathrm{N}$ : tamanho da amostra.

Casos não-declarados: 2.

Como pode ser observado na Tabela 4 , a vasta maioria dos colonos $(88 \%)$ saiu de uma região rural, sendo que destes, cerca de $69 \%$ tiveram experiência anterior no meio rural, seja como proprietário $(30 \%)$, arrendatário $(15,8 \%)$, meeiro $(14,8 \%)$, posseiro $(4,4 \%)$ ou diarista $(2,7 \%)$.

Quando se analisa o período médio de residência na propriedade, constata-se que este foi de 13 anos. Entretanto, verifica-se que cerca de $40 \%$ dos entrevistados chegaram à região amazônica entre 16 e 26 anos anteriores à data em que foi realizada a coleta de dados (julho de 1996) (Tabela 5). 
Tabela 5. Período médio de residência dos colonos na propriedade no Projeto de Colonização de Uruará/PA, 1996.

\begin{tabular}{lcc}
\hline & \multicolumn{2}{c}{ Amostra } \\
\cline { 2 - 3 } \multicolumn{1}{c}{ Anos } & Tamanho da Amostra & Participação (\%) \\
\hline $0-5$ & 26 & 16,0 \\
$6-10$ & 42 & 26,0 \\
$11-15$ & 31 & 19,1 \\
$16-20$ & 30 & 18,5 \\
$>21$ & 33 & 20,4 \\
\hline Total & 162 & 100,0 \\
\hline
\end{tabular}

Fonte: Dados da amostra.

Média da amostra: 13,17.

Desvio padrão: 7,00 .

Casos não-declarados: 1 .

A idade média do chefe da família foi de 48 anos, aproximadamente, na época da coleta dos dados, e em todas as propriedades, exceto em uma, o chefe da família era do sexo masculino, o que não é surpresa em regiões de fronteira como a Amazônia.

Com relação ao tamanho médio da família, esta compreendia sete membros aproximadamente, sendo que, na média, ela era composta por dois homens adultos (entre 15 e 65 anos), duas mulheres adultas (entre 15 e 65 anos) e três crianças (entre zero e 14 anos). Cabe, aqui, ressaltar que dez famílias entrevistadas não moravam na propriedade, ou seja, tinham casa na cidade e apenas trabalhavam na propriedade durante o dia. Observa-se também que o número de pessoas idosas na amostra foi muito pequeno, quase zero.

Por outro lado, quando se trata de nível de escolaridade, constata-se que quase $40 \%$ dos entrevistados não possuíam nenhum tipo de educação formal, com $16,9 \%$ dos entrevistados tendo cursado da $1^{\mathrm{a}}$ à $4^{\mathrm{a}}$ série do ensino básico fundamental e apenas $3,2 \%$ dos colonos possuindo o ensino básico fundamental completo. Conseqüentemente, observa-se que o nível de educação formal médio do chefe de família vai um pouco além de dois anos (Tabela 6). 
Tabela 6. Nível de escolaridade formal do chefe de família no Projeto de Colonização de Uruará/PA, 1996.

\begin{tabular}{lcc}
\hline & \multicolumn{2}{c}{ Amostra } \\
\cline { 2 - 3 } Nível de Escolaridade & $\mathrm{N}$ & $\%$ do total \\
\hline Nenhum nível de escolaridade & 62 & 40,3 \\
Ensino Básico $\left(1^{\mathrm{a}}\right.$ a $4^{\mathrm{a}}$ série $)$ & 50 & 32,5 \\
$\quad$ Incompleto & 26 & 16,9 \\
$\quad$ Completo & & \\
Ensino Básico $\left(5^{\mathrm{a}}\right.$ a $8^{\mathrm{a}}$ série $)$ & 11 & 7,1 \\
$\quad$ Incompleto & 5 & 3,2 \\
$\quad$ Completo & & - \\
Ensino Médio & - & 100,0 \\
$\quad$ Até o $1^{\circ}$ ano completo & 154 & \\
\hline Total &
\end{tabular}

Fonte: Dados da pesquisa.

Média da amostra: 2,14.

Casos não-declarados: 9 .

\subsection{Características das propriedades: tipo de posse, crédito e assistência técnica}

$\mathrm{Na}$ análise da posse da terra, constata-se que $47,9 \%$ dos colonos amostrados possuíam o título definitivo da propriedade. Cerca de 19,2\% tinham título provisório expedido por umas das agências responsáveis pela legalização da terra (Incra ou Iterpa). Os remanescentes 32,9\% não possuíam nenhum tipo de documentação legal da propriedade, sendo posseiros ou colonos que a compraram de outros colonos, ou ainda, aqueles assentados pelas próprias agências responsáveis, sem terem recebido qualquer documentação de posse, ou colonos recém-chegados à região $(\text { Tabela } 7)^{21}$, o que pode ser comprovado na análise do tempo de residência. Nesta análise, o tempo médio de residência foi de 13 anos aproximadamente, com variação de zero a 25 anos, significando que a amostra abrangeu tanto colonos recém-chegados quanto os que participaram do projeto desde sua instalação. Contudo, quando procura-se analisar a integração entre os colonos, constata-se que, apesar do grande número de colonos na

${ }^{21}$ Como alguns colonos, na amostra, possuíam mais de um lote, objetivou-se apenas identificar se tinham ou não título de propriedade de um dos lotes. 
área em estudo, a maioria não fazia parte de nenhum tipo de associação ou organização, onde somente $30 \%$ eram membros de alguma associação, o que dificultava por sua vez uma melhor integração com o mercado.

Tabela 7. Situação de posse da terra na amostra do Projeto de Colonização de Uruará/PA, 1996.

\begin{tabular}{lcc}
\hline & \multicolumn{2}{c}{ Lotes } \\
\cline { 2 - 3 } & $\mathrm{N}$ & $\%$ do total \\
\hline Título definitivo & 105 & 47,9 \\
Não-titulada & 72 & 32,9 \\
Título Provisório & 42 & 19,2 \\
\hline Total & 219 & 100,0 \\
\hline
\end{tabular}

Fonte: Dados da pesquisa.

$\mathrm{N}$ : número de lotes amostrados.

O tamanho da propriedade na amostra selecionada segue o padrão definido pelo Incra de 100 hectares, ou seja, um lote. Todavia, já é possível observar na região certa tendência à concentração da propriedade da terra, com alguns colonos possuindo mais de um lote. Por outro lado, quando analisa-se a localização destas propriedades, em relação à rodovia Transamazônica, ou "faixa", como é normalmente conhecida pelos colonos, a distância média é 13 quilômetros, sendo que algumas propriedades estavam localizadas ao longo da rodovia e outras nos finais dos travessões (ou "linhas").

No caso das propriedades localizadas no fim dos travessões, a distância da propriedade até a faixa podia chegar a mais de 80 quilômetros. Conseqüentemente, as dificuldades de locomoção na área em estudo são enormes. Os colonos geralmente necessitam tomar ônibus ou carona na carroceria de algum caminhão, no mínimo uma vez na semana para ir à cidade, o que representa para alguns, um dia a menos de trabalho, dado que perdem em torno de quatro horas para ir do fundo do travessão até a cidade. Esse tipo de dificuldade costuma ser muito maior na estação das chuvas, quando determinados trechos são intransitáveis. Por conseguinte, a comercialização da produção 
fica restrita aos horários dos "ônibus de linha", ou a um prévio acordo com os cerealistas da região para apanhar a produção na porteira da propriedade. Entretanto, mesmo esses acordos estão restritos ao montante a ser comercializado.

Uma das promessas do governo federal, no início do processo de colonização da Amazônia, estava centrada em infra-estrutura e assistência técnica aos colonos. Todavia, somente $18,2 \%$ dos lotes amostrados puderam contar com assistência técnica desde que chegaram à região (Tabela 8).

Tabela 8. Recebimento de assistência técnica no Projeto de Colonização de Uruará/PA, 1996.

\begin{tabular}{lcc} 
& \multicolumn{2}{c}{ Lotes } \\
\cline { 2 - 3 } \multicolumn{1}{c}{ Órgão } & $\mathrm{N}$ & $\%$ dos lotes \\
\hline Emater & 18 & 8,8 \\
Embrapa & 1 & 0,5 \\
Ceplac & 8 & 3,9 \\
Emater/Embrapa & 1 & 0,5 \\
Emater/Ceplac & 2 & 1,0 \\
Embrapa/Ceplac & 1 & 0,5 \\
Emater/Embrapa/Ceplac & 1 & 0,5 \\
Outro & 5 & 2,5 \\
\hline Total & 37 & 18,2 \\
\hline
\end{tabular}

Fonte: Dados da pesquisa.

$\mathrm{N}$ : número de lotes que receberam algum tipo de ajuda.

Casos não-declarados: 15.

Total de lotes na amostra $=219$.

Por outro lado, na Tabela 9 observa-se que, diferentemente da situação de completa falta de assistência técnica, mais de $50 \%$ dos lotes amostrados tiveram crédito para financiamento de algum tipo de atividade. Contudo, quando se observa a utilização do crédito rural, constata-se que as duas maiores atividades estão ligadas à pecuária e ao plantio de culturas perenes. Nesse caso, observa-se que 16,0\% dos lotes amostrados utilizaram o crédito rural para financiamento de atividades de cunho pecuário, tais como 
formação de pastagens, compra de gado, construção de curral, etc. e que 14,2\% utilizaram-no para atividades ligadas à pecuária e ao plantio de culturas perenes (Tabela 10).

A utilização de crédito para financiamento de atividades pecuárias nas áreas de fronteira não chega a surpreender, mesmo entre os pequenos produtores, uma vez que a criação de gado representa uma espécie de "poupança viva", ou seja, os pequenos produtores podem negociá-lo a qualquer momento, de acordo com suas necessidades.

Além dos fatores expostos acima, o transporte do gado pode ser efetuado sem utilização de um meio de locomoção específico, tais como caminhões. Portanto, diferentemente dos produtos agrícolas, que dependem, na maioria das vezes, de meios de transporte para comercialização e estão sujeitos às intempéries do clima, a comercialização do gado não é tão prejudicada na estação chuvosa. Somada a isto, a formação de pastagens é considerada umas das formas de valorização da propriedade nas regiões de fronteira.

Tabela 9. Distribuição do Crédito Rural no Projeto de Colonização de Uruará/PA, 1996.

\begin{tabular}{lcc}
\hline & \multicolumn{3}{c}{ Crédito } \\
\cline { 2 - 3 } & $\mathrm{N}$ & $\%$ do total \\
\hline Não recebeu & 104 & 47,5 \\
Recebeu & 115 & 52,5 \\
\hline Total & 219 & 100,00 \\
\hline
\end{tabular}

Fonte: Dados da pesquisa.

$\mathrm{N}$ : número de lotes.

Muito embora as culturas perenes tenham alguma importância na região, a utilização de insumos na agricultura não é uma prática freqüente entre os colonos amostrados. Conforme observa-se na Tabela $11,71,2 \%$ dos lotes amostrados receberam algum tipo de insumo. Todavia, $66,5 \%$ desses insumos foram utilizados na pecuária. 
Estes números não representam um nível tecnológico avançado na pecuária, pois o item sal mineral representa $66,0 \%$ dos insumos utilizados. Talvez isso possa ser explicado pelo baixo preço desse insumo.

Tabela 10. Utilização do Crédito Rural no Projeto de Colonização de Uruará/PA, 1996.

\begin{tabular}{lrc}
\hline & \multicolumn{2}{c}{ Crédito } \\
\cline { 2 - 3 } Atividades & $\mathrm{N}$ & $\%$ do total \\
\hline Anuais & 9 & 4,1 \\
Perenes & 5 & 2,3 \\
Pecuária & 35 & 16,0 \\
Anuais/Perenes & 5 & 2,3 \\
Anuais/Pecuária & 5 & 2,3 \\
Anuais/Perenes/Pecuária & 22 & 10,0 \\
Anuais/Perenes/Pecuária/Equip./Outros & 1 & 0,5 \\
Perenes/Pecuária & 31 & 14,2 \\
Perenes/Equipamentos & 1 & 0,5 \\
\hline Total & 115 & 52,2 \\
\hline
\end{tabular}

Fonte: Dados da pesquisa.

$\mathrm{N}$ : número de lotes.

Tabela 11. Uso de insumos na amostra do Projeto de Colonização de Uruará/PA, 1996.

\begin{tabular}{lcc}
\hline & \multicolumn{2}{c}{ Insumos } \\
\cline { 2 - 3 } & $\mathrm{N}$ & $\%$ do total \\
\hline Não usou & 63 & 28,8 \\
Usou & 156 & 71,2 \\
\hline Total & 219 & 100,0 \\
\hline
\end{tabular}

Fonte: Dados da pesquisa.

$\mathrm{N}$ : número de lotes.

Quando se analisa especificamente a utilização do crédito, constata-se que dos $52,2 \%$ dos lotes da amostra que adquiriram crédito, $41 \%$ tinham algum tipo de 
titulação. Dos outros $47,5 \%$ que não receberam crédito, aproximadamente $25 \%$ tinham titulação provisória ou definitiva.

Muito embora a titulação da propriedade seja um fator muito importante na concessão do crédito pelos órgãos responsáveis, cabe, aqui, ressaltar que muitos colonos preferem não se aventurar nesse tipo de empréstimo, mesmo possuindo os requisitos considerados mínimos pelas agências responsáveis. O pequeno produtor nas áreas de fronteira tem certa aversão ao risco e, para muitos deles, a receita advinda da produção não cobre os débitos adquiridos com o crédito. Para completar, muitos acham que os altos custos de transações envolvidos na aquisição do crédito não compensam o trabalho despendido.

Tabela 12. Distribuição de insumos no Projeto de Colonização de Uruará/PA, 1996.

\begin{tabular}{lcc}
\hline & & Insumos \\
\cline { 2 - 3 } Tipo de Insumo & $\mathrm{N}$ & $\%$ do total \\
\hline Inseticida & 3 & 1,4 \\
Herbicida & 0 & 0,0 \\
Fungicida & 1 & 0,5 \\
Fertilizante Químico & 5 & 2,3 \\
Fertilizante Orgânico & 1 & 0,5 \\
Vacina & 1 & 0,5 \\
Sal Mineral & 145 & 66,0 \\
\hline Total & 156 & 71,2 \\
\hline
\end{tabular}

Fonte: Dados da pesquisa.

$\mathrm{N}$ : número de lotes.

\subsection{Relações entre as características sociodemográficas e os tipos de uso da terra}

Os sistemas agrícolas praticados pelos pequenos produtores na área em estudo envolvem a adoção de padrões locais de cultivo e adaptações de métodos previamente praticados nas regiões de origem. Muito embora o aprendizado e a adaptação a padrões locais de cultivo sejam ressaltados na literatura, muito pouco foi 
constatado na amostra utilizada. A produção de cupuaçu, planta nativa da região, por exemplo, foi considerada desprezível na amostra, apesar de os colonos relatarem conhecimento sobre o potencial econômico da produção dessa frutífera. A perecibilidade do produto e a baixa tecnologia empregada no processamento tornam inviável na prática o transporte do produto para os grandes centros.

Basicamente, os sistemas de produção na área em estudo são compostos de culturas anuais, perenes e pastagens. Dentre as anuais, as culturas do arroz, feijão e milho são as que mais se destacam, principalmente nas fases iniciais do processo de desmatamento, quando os colonos preferem plantar arroz logo após a primeira derrubada, seguindo-se o feijão e o milho. Além disso, essas culturas são a base alimentação dos produtores da região. Com relação às culturas perenes, o cacau, café e pimenta-do-reino são as mais adotadas.

Uma das mais importantes teorias das causas do desmatamento em florestas tropicais está relacionada ao crescimento populacional e seu posterior avanço para as áreas de fronteiras. Em outras palavras, a degradação dos recursos naturais, tais como o desmatamento, é resultado das grandes pressões populacionais. Em termos de pequena produção familiar, pode-se examinar o relacionamento entre população e intensidade de uso da terra, e seus possíveis efeitos sobre o desmatamento.

$\mathrm{Na}$ Tabela 13, mostra-se a existência de um relacionamento entre o tamanho da família e o uso da terra em cada lote. À medida que o número de membros na família cresce, constata-se o aumento da área média desmatada, tanto em termos da área reportada através do levantamento de campo em 1996 quanto com relação às estimativas efetuadas com sensoriamento remoto para o ano de 1997. Em termos gerais, observa-se que os valores calculados para o ano de 1997 estão abaixo dos valores calculados através dos dados de campo para 1996. Em decorrência disto, duas hipóteses podem ser levantadas. A primeira pode estar relacionada a uma superestimação dos dados coletados em 1996. 
Neste caso, diferentemente da atitude esperada, onde os colonos não responderiam corretamente à verdadeira magnitude do desmatamento, os resultados demonstrariam uma falta de conhecimento do verdadeiro tamanho do desmatamento na propriedade. A segunda hipótese é de que a definição de área desmatada, quando se classifica imagens, são diferentes das adotadas pelos produtores. Ou seja, é muito difícil para os especialistas em sensoriamento remoto conseguir diferenciar áreas com culturas perenes de florestas. Neste caso, poderia haver uma subestimação do verdadeiro valor do desmatamento. Todavia, como ressaltado anteriormente, a análise efetuada é do tipo bivariada e descritiva, não permitindo a análise de outros fatores inter-relacionados que podem estar influenciando o uso da terra.

O aumento (ou diminuição) no número de membros na família eleva (ou reduz) a força de trabalho e, portanto, o uso intensivo da terra. Quando se analisa especificamente os sistemas agrícolas, observa-se que o crescimento da família, pelo lado da oferta de mão-de-obra, parece estar influenciando o crescimento da área média com culturas perenes, uma vez que as utilizadas na região empregam mão-de-obra intensiva. Contudo, na amostra utilizada, o tamanho da família também está positivamente relacionado ao aumento da área média com culturas anuais.

Todavia, isto não chega a surpreender, dado que o aumento no tamanho médio da família pode estar relacionado ao crescimento do número médio de crianças, o que justificaria o aumento na área média com culturas anuais, e talvez justifique o aumento na área média com culturas perenes, uma vez que observa-se na região o uso do trabalho infantil em certas atividades, como colheita e plantio.

Logo, se esta pressuposição estiver correta, há também a necessidade de assegurar a subsistência familiar. Neste contexto, também pode-se argumentar que quanto maior o tamanho da família, maior a demanda por alimento, o que é refletido no aumento na área média com culturas anuais. 
O que não fica claro nesse tipo de análise é se a causa do relacionamento entre tamanho da família e desmatamento é decorrência do aumento da força de trabalho ou da maior necessidade de assegurar a subsistência.

Padrões de uso da terra na área em estudo também podem ser influenciados pelo tipo de posse da terra. A Tabela 14 apresenta o relacionamento que existe na amostra entre o tipo de posse da propriedade e as formas de uso da terra. Observa-se que a maioria dos respondentes tinha algum tipo de certificado de posse, definitivo $(47,3 \%)$ ou provisório $(19,9 \%)$.

A hipótese que prevalece na visão neoclássica sobre direito de propriedade estabelece que a posse definitiva da terra proporcionaria uma visão de longo prazo das conseqüências negativas da degradação ambiental e, como reflexo, da desvalorização do patrimônio.

Tabela 13. Relação entre tamanho da família e uso da terra no Projeto de Colonização de Uruará/PA, 1996.

\begin{tabular}{lccccc}
\hline Tamanho & \multicolumn{5}{c}{ Tipo de uso da terra (em hectares) } \\
\cline { 3 - 6 } da família & Anuais & Perenes & Pastagens & $\begin{array}{c}\text { Desmatamento } \\
\text { dados de campo } \\
(1996)\end{array}$ & $\begin{array}{c}\text { Desmatamento } \\
\text { imagens } \\
(1997)\end{array}$ \\
\hline$<4$ & 2,71 & 6,54 & 26,57 & 44,18 & 42,26 \\
& $(3,62)$ & $(9,15)$ & $(15,84)$ & $(22,10)$ & $(33,60)$ \\
$4-6$ & 8,05 & 6,73 & 45,67 & 63,00 & 47,61 \\
& $(11,82)$ & $(7,48)$ & $(43,96)$ & $(57,37)$ & $(31,02)$ \\
$6-8$ & 6,46 & 3,50 & 41,87 & 60,29 & 46,50 \\
& $(4,79)$ & $(5,74)$ & $(28,37)$ & $(28,96)$ & $(33,87)$ \\
$8-10$ & 7,36 & 5,52 & 30,97 & 53,13 & 57,91 \\
& $(4,58)$ & $(6,82)$ & $(15,05)$ & $(19,22)$ & $(27,48)$ \\
$>10$ & 7,33 & 13,64 & 41,42 & 71,05 & 66,47 \\
& $(4,57)$ & $(15,62)$ & $(31,49)$ & $(38,44)$ & $(39,39)$ \\
\hline
\end{tabular}

Fonte: Dados da pesquisa.

Obs.: Os valores entre parênteses são desvios padrão. 
No caso do desmatamento, esta visão estabelece que a posse definitiva da terra eliminaria a necessidade de aumentar a área desmatada, como forma de garantir o direito de posse (usucapião). Todavia, a Tabela 14 não confirma esta argumentação, quando são utilizados os dados de campo de 1996, uma vez que os colonos que não possuem o direito legal da terra desmatam menos do que aqueles que possuem algum tipo de certificado de posse.

Já com relação ao ano de 1997, também observa-se que os colonos sem documentação de posse desmatam menos do que aqueles que possuem a titulação definitiva. Neste contexto, o direito de propriedade parece estar indiretamente estimulando o desmatamento, uma vez que com a posse definitiva da propriedade, os colonos podem usá-la como garantia de empréstimos que, como já foi visto, foram utilizados na maioria dos casos em insumos pecuários.

Nota-se, também, que de uma maneira geral, os colonos que não possuem documentação são os que usam a terra de maneira menos intensiva, em comparação aos que possuem algum tipo de certificado.

Tabela 14. Relação entre tipo de propriedade da terra e tipo de uso da terra no Projeto de Colonização de Uruará/PA, 1996.

\begin{tabular}{|c|c|c|c|c|c|c|}
\hline \multirow{2}{*}{$\begin{array}{l}\text { Tipo de } \\
\text { propriedade } \\
\text { da terra }\end{array}$} & \multirow{2}{*}{$\begin{array}{l}\mathrm{N} \\
\%\end{array}$} & \multicolumn{5}{|c|}{ Uso da terra (em hectares) } \\
\hline & & Anuais & Perenes & Pastagens & $\begin{array}{c}\text { Desmatamento } \\
\text { dados de campo } \\
\text { (1996) }\end{array}$ & $\begin{array}{c}\text { Desmatamento } \\
\text { imagens } \\
\text { (1997) }\end{array}$ \\
\hline \multirow[t]{2}{*}{ Não-titulada } & 72 & 5,43 & 6,31 & 31,08 & 49,11 & 43,77 \\
\hline & $32,9 \%$ & $(4,55)$ & $(10,73)$ & $(24,44)$ & $(29,19)$ & $(33,31)$ \\
\hline \multirow[t]{2}{*}{ Provisório } & 42 & 8,70 & 4,43 & 35,64 & 57,34 & 42,47 \\
\hline & $19,2 \%$ & $(10,93)$ & $(6,91)$ & $(35,10)$ & $(47,07)$ & $(28,76)$ \\
\hline \multirow[t]{2}{*}{ Titulada } & 105 & 6,23 & 9,12 & 43,87 & 66,61 & 61,50 \\
\hline & $47,9 \%$ & $(6,34)$ & $(15,32)$ & $(31,97)$ & $(38,35)$ & $(35,06)$ \\
\hline
\end{tabular}

Fonte: Dados da pesquisa.

$\mathrm{N}$ : tamanho da amostra.

Os valores entre parênteses para cada tipo de uso da terra são desvios padrão. 
Constata-se, coeteris paribus, através da análise descritiva apresentada, que em geral, à medida que a posse da terra é assegurada, um uso mais intensivo dos lotes é alcançado, com um aumento da área média com culturas perenes e pastagens. Esta situação não chega a surpreender, dado que estas atividades são as que necessitam de maiores investimentos e que, em termos de financiamento, dos $52 \%$ dos lotes que receberam crédito, mais de $40 \%$ tinham algum tipo de certificado de posse.

Por outro lado, deve-se atentar para o fato de que, na região da rodovia Transamazônica, o título definitivo da propriedade está relacionado, também, ao período de residência na área, ou seja, aqueles colonos assentados no início do processo de colonização receberam seus certificados primeiro e, conseqüentemente, devem ter desmatado mais, o que não é captado na análise.

Outro fator importante quando se analisa o desmatamento em áreas de fronteira está relacionado à hipótese, sempre levantada na literatura, da influência do mercado na tomada de decisão do uso da terra. Em outras palavras, como a acessibilidade ao mercado afeta o uso da terra ${ }^{22}$. A Tabela 15 apresenta os efeitos da distância nos padrões de uso da terra e, como conseqüência, no desmatamento. Como está evidenciado nesta tabela, parece existir um padrão entre distância e desmatamento, ou seja, quanto mais próximo da "faixa", maior a área desmatada. Tal fato pode ser confirmado tanto através dos dados de campo para 1996, como através das imagens de satélite para 1997.

Em relação aos diferentes usos da terra, o impacto da distância, ou da acessibilidade ao mercado, dá-se de diferentes formas. Em primeiro lugar, os resultados indicam haver uma distância limite da faixa na qual o uso de pastagens é mais intensivo. Em outras palavras, até a uma distância inferior a sete quilômetros, a pecuária parece ser o sistema de uso da terra mais utilizado. Por outro lado, os resultados também demonstram que à medida que a distância aumenta, a área total com pastagens diminui.

\footnotetext{
${ }^{22}$ Aqui, a acessibilidade ao mercado é caracterizada pela distância da propriedade em relação à rodovia Transamazônica (ou "faixa", como é conhecida pelos colonos).
} 
Em segundo lugar, não parece claro nos resultados haver uma evidência de um maior uso intensivo de culturas perenes nas propriedades mais próximas da rodovia Transamazônica e de culturas anuais nas propriedades mais distantes da "faixa".

Contudo, se tentássemos especular sobre estas evidências, dois pontos importantes, deveriam ser destacados. Em primeiro lugar, observa-se que os colonos que migraram para a região depois de o projeto já estar estabelecido não conseguiram lotes perto da rodovia, ou seja, estão assentados nos fundos dos travessões. Somado-se a isso, estes colonos, os assentados recentemente pelo Incra, ou até mesmo os posseiros, têm como uma das características principais, um grande número de membros na família em idade infantil, isto é, têm um grande número de consumidores em relação ao número de produtores, o que os torna dependentes de culturas anuais. Em segundo lugar, os colonos assentados mais perto da "faixa" foram os primeiros a desmatarem para plantar, dessa forma, ao longo do tempo, com uma maior degradação do solo e o envelhecimento da família, podem ter optado por atividades poupadoras de mão-de-obra, tais com a pecuária.

Muito embora os resultados não sejam completamente diferentes dos encontrados na literatura, cabe, aqui, frisar que não se consegue distinguir com precisão quanto do efeito sobre o desmatamento é decorrente do fator acessibilidade ao mercado, quanto decorre do tempo de residência na propriedade, ou quanto decorre da própria estrutura da família.

Assim sendo, na Tabela 16 apresentam-se os resultados dos padrões de uso da terra em relação ao tempo de residência na propriedade. Observa-se através destes uma evolução da área média desmatada ao longo do tempo. Por exemplo, para propriedades com tempo de residência entre 10 e 13 anos, a área média desmatada foi de 51 hectares (considerando-se os dados de campo para 1996), superior aos 48 hectares para propriedades com tempo de residência entre três e cinco anos. Tal conclusão pode também ser visualizada para propriedades com mais de 16 anos de atividade. Por outro lado, apesar de não ser tão evidente quando se analisa as imagens para o ano de 1997, 
parece também haver uma tendência a um aumento da área desmatada ao longo do tempo.

Em relação aos sistemas de uso da terra, tal como os resultados anteriores, há somente evidências da influência do tempo de residência na escolha dos sistemas agrícolas. Por exemplo, à medida que o tempo de residência na propriedade aumenta, aumentam também as áreas com pastagens, com culturas perenes e há uma evidente variação no tamanho da área com culturas anuais ao longo do tempo. Com o uso do sistema de "derruba e queima" em florestas tropicais, não é de se estranhar que o tamanho da área varie tanto ao longo dos anos, tanto em decorrência da própria degradação do solo como em decorrência do próprio ciclo de vida da família.

Em conclusão, é preciso ter em mente que, dada a pobreza dos solos na região, não seria surpresa constatar uma degradação maior dos solos em decorrência do tempo de residência, bem como uma possível tendência em direção a maiores áreas com pastagens ou, até mesmo, abandono das áreas com culturas para pousio. Contudo, a nãodisponibilidade de dados, impossibilita uma análise mais profunda da pressuposição. Destarte, é necessário lembrar que fatores institucionais e demográficos podem sofrer mudanças ao longo do tempo e que estes não são controladas por análises bivariadas, como as usadas no presente trabalho. Todavia, este tipo de análise não invalida as especulações levantadas e que podem ser testadas em análises multivariadas. 
Tabela 15. Relação entre distância média e tipos de uso da terra no Projeto de Colonização de Uruará/PA, 1996.

\begin{tabular}{cccccc}
\hline $\begin{array}{c}\text { Distância } \\
\text { da faixa } \\
(\mathrm{Km})\end{array}$ & Anuais & Perenes & Pastagens & $\begin{array}{c}\text { Desmatamento } \\
\text { Dados de campo } \\
(1996)\end{array}$ & $\begin{array}{c}\text { Desmatamento } \\
\text { Imagens } \\
(1997)\end{array}$ \\
\hline$<3$ & & & 62,05 & 69,73 \\
& 5,93 & 13,20 & 36,97 & $(26,08)$ & $(16,99)$ \\
$3-5$ & $(3,58)$ & $(18,45)$ & $(21,95)$ & 61,50 & 64,37 \\
& 3,76 & 4,34 & 39,75 & $(19,47)$ & $(15,53)$ \\
$5-7$ & $(3,61)$ & $(5,02)$ & $(16,68)$ & 59,28 & 64,67 \\
& 4,86 & 2,86 & 44,11 & $(34,49)$ & $(31,19)$ \\
$7-10$ & $(3,54)$ & $(3,27)$ & $(29,81)$ & 61,72 & 59,38 \\
& 7,85 & 9,85 & 32,86 & $(30,13)$ & $(32,27)$ \\
$10-14$ & $(5,04)$ & $(14,95)$ & $(21,18)$ & 53,74 & 42,05 \\
& 6,08 & 6,23 & 33,33 & $(29,24)$ & $(39,99)$ \\
$>14$ & $(6,07)$ & $(9,49)$ & $(27,16)$ & 36,79 & 28,34 \\
& 5,83 & 2,82 & 24,40 & $(29,03)$ & $(19,22)$ \\
\hline
\end{tabular}

Fonte: Dados da pesquisa.

Os valores entre parênteses são desvios padrão.

Um outro aspecto também sempre considerado na literatura está relacionado à influência do nível de escolaridade na tomada de decisão do uso da terra. A hipótese sempre testada está relacionada à relação inversa entre nível de escolaridade e preocupação ambiental, ou seja, espera-se que pessoas mais "formalmente educadas" sejam as que menos desmatem.

Neste sentido, a Tabela 17 foi construída para examinar a existência de algum tipo de relação entre o nível de escolaridade do chefe da família e o padrão de uso da terra na amostra. Neste caso, utilizaram-se como proxy para o nível de escolaridade os anos totais de escola freqüentados pelo chefe da família. De acordo com a expectativa, apesar de não tão explícito nos dados gerados pelas imagens, um maior nível de escolaridade do chefe da família parece ter relação inversa com a área total

\footnotetext{
${ }^{23}$ O nível de educação será medido no presente trabalho pelos anos de escolaridade formal do chefe da familia.
} 
desmatada, que é também refletido na diminuição da área média com culturas anuais e pastagens.

Tabela 16. Relação entre o tempo de residência na propriedade e o tipo de uso da terra no Projeto de Colonização de Uruará/PA, 1996.

\begin{tabular}{cccccc}
\hline Tempo de & \multicolumn{5}{c}{ Tipos de usos da Terra (em hectares) } \\
\cline { 2 - 6 } $\begin{array}{c}\text { Residência } \\
\text { (anos) }\end{array}$ & Anuais & Perenes & Pastagens & $\begin{array}{c}\text { Desmatamento } \\
\text { dados de campo } \\
(1996)\end{array}$ & $\begin{array}{c}\text { Desmatamento } \\
\text { Imagens } \\
(1997)\end{array}$ \\
\hline$<2,9$ & 7,17 & 5,85 & 26,83 & 48,17 & 49,58 \\
& $(2,89)$ & $(10,04)$ & $(11,52)$ & $(28,03)$ & $(29,07)$ \\
$3-4,9$ & 5,23 & 5,26 & 23,25 & 48,29 & 32,38 \\
& $(5,14)$ & $(8,05)$ & $(17,01)$ & $(32,56)$ & $(29,57)$ \\
$5-6,9$ & 5,26 & 1,76 & 24,32 & 34,53 & 32,06 \\
& $(4,64)$ & $(2,18)$ & $(20,32)$ & $(23,56)$ & $(34,59)$ \\
$7-9,9$ & 8,62 & 3,86 & 29,37 & 45,63 & 35,45 \\
& $(11,34)$ & $(5,67)$ & $(39,28)$ & $(47,58)$ & $(22,58)$ \\
$10-12,9$ & 5,11 & 3,93 & 35,72 & 51,06 & 43,38 \\
& $(3,70)$ & $(4,63)$ & $(31,46)$ & $(36,49)$ & $(37,58)$ \\
$13-15,9$ & 3,95 & 4,00 & 24,58 & 35,60 & 26,89 \\
& $(5,01)$ & $(8,24)$ & $(18,37)$ & $(20,77)$ & $(18,51)$ \\
$>16$ & 6,06 & 8,05 & 36,22 & 57,99 & 61,01 \\
& $(3,70)$ & $(13,91)$ & $(20,02)$ & $(23,31)$ & $(24,95)$ \\
\hline
\end{tabular}

Fonte: Dados da pesquisa.

Os dados entre parênteses são desvios padrão.

Para finalizar a análise, enfatiza-se que a escolha do sistema de uso da terra é a decisão mais importante feita pelo pequeno produtor das áreas de fronteira, sendo os outros tipos de decisão decorrentes dessa escolha. A análise descritiva efetuada nesta seção está focalizada nas escolhas dos sistemas de uso da terra e nas influências dos fatores sociodemográficos e de mercado na tomada de decisão. A análise preliminar efetuada indica que tamanho da família, tempo de residência na propriedade, acesso ao mercado, tipo de posse da terra e nível de escolaridade têm influências negativas e positivas sobre a tomada de decisão de uso da terra. Contudo, é impossível verificar seus 
efeitos conjuntamente na análise descritiva realizada e, evidentemente, será necessário investigá-los em um contexto multivariado.

Tabela 17. Relação entre o nível de escolaridade do chefe da família e os tipos de uso da terra no Projeto de Colonização de Uruará/PA, 1996.

\begin{tabular}{lccccc}
\hline $\begin{array}{l}\text { Anos médios de } \\
\text { escolaridade }\end{array}$ & \multicolumn{5}{c}{ Uso da Terra (em hectares) } \\
\cline { 2 - 6 } & Anuais & Perenes & Pastagens & $\begin{array}{c}\text { Desmatamento } \\
\text { dados de campo } \\
(1996)\end{array}$ & $\begin{array}{c}\text { Desmatamento } \\
\text { imagens } \\
(1997)\end{array}$ \\
\hline$<3$ & 7,29 & 6,51 & 39,35 & 60,70 & 51,82 \\
$3-5$ & $(8,31)$ & $(13,72)$ & $(33,88)$ & $(42,25)$ & $(35,54)$ \\
& 5,33 & 8,35 & 38,89 & 61,04 & 54,83 \\
$5-7$ & $(4,18)$ & $(9,89)$ & $(26,97)$ & $(32,55)$ & $(35,18)$ \\
& 6,19 & 15,06 & 21,17 & 38,61 & 39,23 \\
$>7$ & $(5,70)$ & $(18,73)$ & $(11,77)$ & $(10,67)$ & $(17,60)$ \\
& 2,56 & 2,55 & 29,12 & 38,37 & 45,44 \\
& $(1,54)$ & $(4,38)$ & $(11,54)$ & $(12,78)$ & $(20,47)$ \\
\hline
\end{tabular}

Fonte: Dados da pesquisa.

Os valores entre parênteses são os desvios padrão.

Dado que pouco se conhece a respeito das tomadas de decisão de uso da terra nas áreas de fronteira, preconcebidas noções sobre uso da terra que se focalizam em somente uma ou duas dimensões, como, por exemplo, fatores sociodemográficos e de mercado, podem levar a um incorreto entendimento das interações existentes entre cada tipo de uso. Desta forma, cada decisão feita pelo produtor tem implicações em outros tipos. Conseqüentemente, uma completa análise das decisões de alocação deve levar em conta essas inter-relações. Assim sendo, na próxima seção busca-se testar empiricamente estas inter-relações. 


\subsection{O modelo econométrico de desmatamento utilizado}

O principal objetivo desta seção é apresentar um modelo de regressão que considere as relações existentes entre as características sociodemográficas da família, as influências do mercado e as influências institucionais no direcionamento da tomada de decisão de desmatar. Em outras palavras, busca-se analisar conjuntamente os efeitos de cada uma dessas características no processo de desmatamento. Para isso, a análise estatística utilizada baseia-se no Método dos Mínimos Quadrados Ordinários e nas Técnicas de Análise Espacial.

Para se testar o modelo conceitual proposto, análises de regressões foram feitas com base em 153 observações. A diferença entre a amostra de 163 observações utilizada na análise descritiva e a amostra de 153 utilizada nas análise de regressões ocorreu devido às limitações do Software de análise espacial SpaceStat, que exige que dados não-declarados sejam eliminados da amostra. Dessa forma, 10 observações tiveram que ser eliminadas na presente análise.

\subsubsection{Análise de regressão}

Autocorrelação espacial é um problema comum em dados geográficos, uma vez que áreas próximas uma das outras têm maiores chances de apresentar similaridades do que as mais distantes delas. Este tipo de problema pode resultar em estimativas ineficientes e viesadas. Segundo Chomitz \& Gray (1996) e Rosero-Bixby \& Palloni (1996), existem vários métodos que parcialmente podem corrigir os problemas de autocorrelação espacial, muito embora nenhum seja plenamente satisfatório. Para Kaimowitz \& Angelsen (1998), a autocorrelação espacial é particularmente um sério problema se o objetivo principal da pesquisa é determinar como cada variável independente afeta o uso da terra.

Assim sendo, modelos de desmatamento como o proposto na presente pesquisa estão susceptíveis a problemas de autocorrelação espacial, uma vez que dados georreferenciados são utilizados. A fim de se testar o modelo conceitual proposto 
anteriormente, e com o intuito de eliminar as preocupações existentes com problemas de autocorrelação espacial, dois modelos econométricos foram estimados através do Método dos Mínimos Quadrados Ordinários de tal forma que seus resíduos pudessem ser examinados utilizando-se o Software SpaceStat.

A autocorrelação espacial ocorre quando variáveis utilizadas na análise estão correlacionadas com elas mesmas no espaço (Odland, 1988), o que, em termos de regressão, significa que a variável dependente ou o termo de erro está espacialmente autocorrelacionada. Sendo assim, dois tipos de autocorrelação podem se fazer presentes. Primeiro, quando a variável dependente está correlacionada com ela mesma no espaço, é a chamada Autocorrelação Espacial Substantiva. A segunda, é a Autocorrelação Espacial dos Erros, criada pela correlação do termo de erro no espaço. Neste contexto, quando ambos os casos ocorrem, as estimativas dos coeficientes do método de mínimos quadrados ordinários podem ser viesadas (Anselin \& Rey, 1991).

$\mathrm{Na}$ presente pesquisa os diagnósticos para os problemas de autocorrelação espacial foram calculados para dois modelos separadamente: um considerando o tamanho da família e a dependência (Modelo 1), e o outro, considerando o desmembramento da família em total de homens, mulheres, crianças e idosos (Modelo 2). Nos dois casos, os resultados são baseados na amostra contendo informações georreferenciadas $(\mathrm{n}=153)$.

Os diagnósticos baseados no teste de Moran I apenas indicam se o modelo testado apresenta ou não problemas de autocorrelação espacial. Todavia, o referido teste não especifica o tipo de problema. Autores como Walker et al. (2000), estudando o processo de desmatamento associado a pequenos produtores e pecuaristas na Amazônia, constataram a não-existência de problemas de autocorrelação espacial para vizinhanças de $7.000,20.000$ e 40.000 metros. Todavia, estes autores ressaltam que não há a priori um meio de se definir as distâncias a serem testadas quando se define uma vizinhança.

A Tabela 18 apresenta os testes de Moran I e dos Multiplicadores de Lagrange. Estes testes foram computados para três matrizes de distância necessárias na 
implementação da matriz de contiguidade, definidas para as vizinhanças de 10.000 , 20.000 e 30.000 metros.

Tabela 18. Avaliação dos efeitos espaciais.

\begin{tabular}{lccccccc}
\hline & \multicolumn{3}{c}{ Modelo 1 } & & & \multicolumn{3}{c}{ Modelo 2 } \\
\cline { 2 - 5 } \cline { 7 - 8 } & 10,000 & 20,000 & 30,000 & & 10,000 & 20,000 & 30,000 \\
\hline Teste de & 2,51 & 0,79 & 0,18 & & 2,45 & 0,36 & 0,35 \\
Moran I & $(0,012)$ & $(0,430)$ & $(0,856)$ & & $(0,014)$ & $(0,721)$ & $(0,727)$ \\
$\begin{array}{l}\text { Multiplicador } \\
\text { de Lagrange }\end{array}$ & 3,15 & 0,00 & 0,20 & & 2,95 & 0,07 & 0,67 \\
para Erros & $(0,076)$ & $(0,943)$ & $(0,650)$ & & $(0,086)$ & $(0,784)$ & $(0,413)$ \\
$\begin{array}{l}\text { Multiplicador } \\
\text { de Lagrange }\end{array}$ & 5,69 & 0,15 & 0,19 & & 5,59 & 0,05 & 0,28 \\
para Lag & $(0,017)$ & $(0,694)$ & $(0,650)$ & & $(0,018)$ & $(0,815)$ & $(0,599)$ \\
\hline
\end{tabular}

Fonte: Cálculos do autor.

Obs: os valores entre parênteses são os respectivos níveis de significância.

Como relatado anteriormente, os diagnósticos baseados no teste de Moran I apenas indicam se o modelo testado apresenta ou não problemas de autocorrelação espacial. Todavia, o referido teste não especifica o tipo de problema. Assim sendo, observa-se que os dois modelos testados apresentam problemas de autocorrelação espacial nas vizinhanças de até 10.000 metros. Neste caso, baseados nos testes dos Multiplicadores de Lagrange, identifica-se que para lotes na vizinhança de até 10.000 metros, os dois modelos apresentam problemas de autocorrelação espacial de erro, bem como problemas de autocorrelação espacial de lag.

Contudo, segundo Anselin (1988), em casos como este deve-se optar pelo modelo com maior nível de significância. Sendo assim, os dois modelos apresentam padrões de autocorrelação espacial substantiva (ou de Lag). Em outras palavras, é provável que o desmatamento que ocorre em determinado lote influencie o desmatamento em outro lote, na vizinhança de até 10.000 metros. 
Dado que foi possível identificar o tipo de problema espacial existente, a próxima etapa é a estimação dos dois modelos propostos, através da estimativa de Máxima Verossimilhança para modelos espacialmente defasados (Tabela 19).

Em primeiro lugar, note-se que alguns parâmetros são significantes e outros não, incluindo o parâmetro $\rho$ associado com a variável espacialmente defasada desmatamento. Se compararmos as estimativas de Mínimos Quadrados Ordinários com as estimativas de Máxima Verossimilhança, constatamos que estas são um pouco diferentes. Segundo Anselin (1988), espera-se uma mudança nos coeficientes da regressão na maioria das vezes em que um modelo espacialmente defasado é altamente significante, dado que as estimativas de MQO são viesadas em decorrência da omissão de uma variável explicativa significante, WY. Por outro lado, se o parâmetro $\rho$ não for significante, não haverá variações substanciais entre as estimativas de MQO quando comparadas às estimativas de MV. Além disso, pode-se avaliar a melhoria destes modelos através das medidas de probabilidades (LIK e AIC). Neste contexto, uma redução no valor de AIC e um aumento no valor absoluto de LIK indicam uma melhora do modelo de Autocorrelação Espacial Defasado em relação ao modelo de Mínimos Quadrados Ordinários.

A regressão espacial, para os dois modelos de desmatamento propostos, resultou em um $\mathrm{R}^{2}$ de $43,02 \%$ e $43,47 \%$, respectivamente. Sendo que para os dois modelos testados, a variável desmatamento defasado foi significante ao nível de $10 \%$ de probabilidade. Esta variável confirma a existência de agrupamentos de desmatamento detectados anteriormente pelo teste de Moran I.

Com relação às variáveis distância, tamanho da família, dependência e crédito na propriedade, constata-se que estas foram estatisticamente significantes, ao nível de $5 \%$. Por outro lado, das variáveis que medem a influência do nível de riqueza inicial sobre o desmatamento, apenas as variáveis riqueza 2 e 3 foram significantes ao nível de $1 \%$ de probabilidade. 
Com relação ao modelo 2 , observa-se que a variável total de homens na família foi significante ao nível de $10 \%$ de probabilidade. Além disso, verificou-se que as variáveis distância e crédito foram significantes ao nível de $5 \%$, com as variáveis riquezas 2 e 3 sendo significantes ao nível de 1\%. Portanto, a significância estatística para o coeficiente da variável desmatamento defasado nos dois modelos indica que há presença de agrupamentos de desmatamento.

Tal como esperado, observa-se que nos dois modelos testados, o efeito substantivo da variável acessibilidade ao mercado (representada pela "proxy" distância) é bastante significativo na tomada de decisão de desmatar. Neste caso, pode-se argumentar que quanto maior a distância em relação à "faixa", maior é a probabilidade de que a terra permanecerá em floresta. Em outras palavras, um quilômetro a mais em direção ao fundo do travessão, representa mais de meio hectare que deixa de ser desmatado. Outros estudos têm considerado o papel que as rodovias e a proximidade do mercado assumem em explicar o desmatamento. Wear \& Bolstad (1998), por exemplo, argumentam que o uso da terra e o desmatamento são determinados conjuntamente e que a acessibilidade ao mercado afeta o uso da terra que, por sua vez, determina o desmatamento. Nossa abordagem segue esta linha geral de pensamento, uma vez que as rodovias existem a priori às decisões de imigrar.

Se observarmos a análise descritiva feita anteriormente sobre a influência da distância no tipo de uso da terra, constataríamos que colonos assentados em propriedades mais próximas da "faixa", e por conseguinte do mercado, são aqueles que têm maiores áreas desmatadas, com maiores áreas em pastagens e culturas perenes. Por outro lado, observa-se na região que colonos com pouca acessibilidade ao mercado são mais dependentes de culturas de subsistência.

De maneira geral, os resultados apresentados aqui estão em consonância com os resultados de Walker et al. (no prelo). Segundo estes autores, os colonos localizados mais perto do mercado, na região da rodovia Transamazônica, podem ser caracterizados como "especializados em pecuária", "especializados em perenes com pecuária" ou 
"especializados em perenes com anuais". A partir deste ponto de vista, pode-se supor que quanto maior a distância, maiores serão os custos de transporte, menores os preços do produto na propriedade e maior o preço dos insumos, tal que menores áreas serão desmatadas. Muitos estudos mostram que o desmatamento decresce rapidamente a partir de dois a três quilômetros da rodovia principal, muito embora Liu et al. (1993) e Mamingi et al. (1996) reportem significantes desmatamentos associados com maiores distâncias em Camarões, nas Filipinas e no Zaire. De forma semelhante, Mertens \& Lambin (1997) afirmam que o desmatamento diminui dramaticamente para distâncias maiores que 10 quilômetros em Camarões. Assim, de maneira geral, pode-se afirmar que a distância está presumivelmente associada ao custo de transporte das mercadorias que, por sua vez, influencia o sistema de uso da terra a ser utilizado.

Analisando-se a influência do tamanho da família sobre a área total desmatada, verifica-se que famílias com poucos membros são aquelas com maiores probabilidades de estarem associadas a maiores áreas com florestas, enquanto uma maior disponibilidade de mão-de-obra estará associada a maiores áreas desmatadas. Através da análise descritiva, observou-se que na região, as famílias maiores estão associadas com maiores áreas em perenes, maiores áreas com pastagens e maiores áreas com culturas anuais. De uma maneira geral, a análise multivariada constatou existir influência do tamanho da família sobre o desmatamento.

Por outro lado, se desmembrássemos a variável tamanho da família, observaríamos que apenas a variável total de homens na família teria forte significância sobre a área total desmatada. Neste caso, constata-se que os efeitos da força masculina se faz presente, pelo menos pelo lado da oferta de mão-de-obra, uma vez que estes estão mais envolvidos no processo de limpeza da área (desmatamento). Contudo, apesar do efeito de um homem a mais sobre a área total desmatada ser maior, seu nível de signifícância é menor do que o da variável tamanho da família. De qualquer forma, estes resultados não chegam a surpreender uma vez que confirmam a natureza intensiva do fator trabalho nas atividades agrícolas empregadas na região, principalmente nas culturas do cacau, café e pimenta-do-reino. 
Muñoz (1992), Monela (1995), Godoy et al. (1996) e Pichón (1997) concluem que grandes famílias desmatam mais a cada ano e deixam cada vez menos áreas com florestas em suas propriedades. Por outro lado, Godoy et al. (1997), relatou que grandes famílias indígenas em Honduras desmatavam cada vez menos, e Holden et al. (1997) não observou relações entre tamanho da família e área total desmatada em Zâmbia.

Considerando-se o efeito da variável dependência sobre a área total desmatada, verifica-se, tal como esperado, que quanto maior a dependência, menor a área desmatada. Portanto, pode-se sugerir que, em termos do modelo proposto, tanto o lado da oferta de mão-de-obra como o lado da demanda (consumo) são significantes na análise da dinâmica de uso da terra. Portanto, considerando-se as variáveis que diretamente refletem estágios do ciclo de vida da família, tais como idade do chefe da família, tempo de residência na propriedade, dependência e tamanho da força de trabalho, apenas as últimas duas parecem influenciar a área desmatada, nos dois modelos propostos. Contudo, apesar da variável tempo de residência não ter sido significante, o resultado não chega surpreender.

Godoy et al. (1997) verifica que a área total desmatada diminui em Honduras para famílias indigenas ao longo do tempo, o que pode estar refletindo estágios avançados no ciclo de vida. Diferentemente de outros estudos, a variável diárias não se apresentou significante em nenhum dos modelos propostos. Neste caso, é possível que esta variável seja endógena ao modelo, e não exógena como pressuposto, uma vez que a contratação de mão-de-obra assalariada está altamente relacionada ao nível de riqueza da família. Se assim for, quanto maior o nível de riqueza, maior seria a contratação de mãode-obra e, conseqüentemente, maior o desmatamento. 


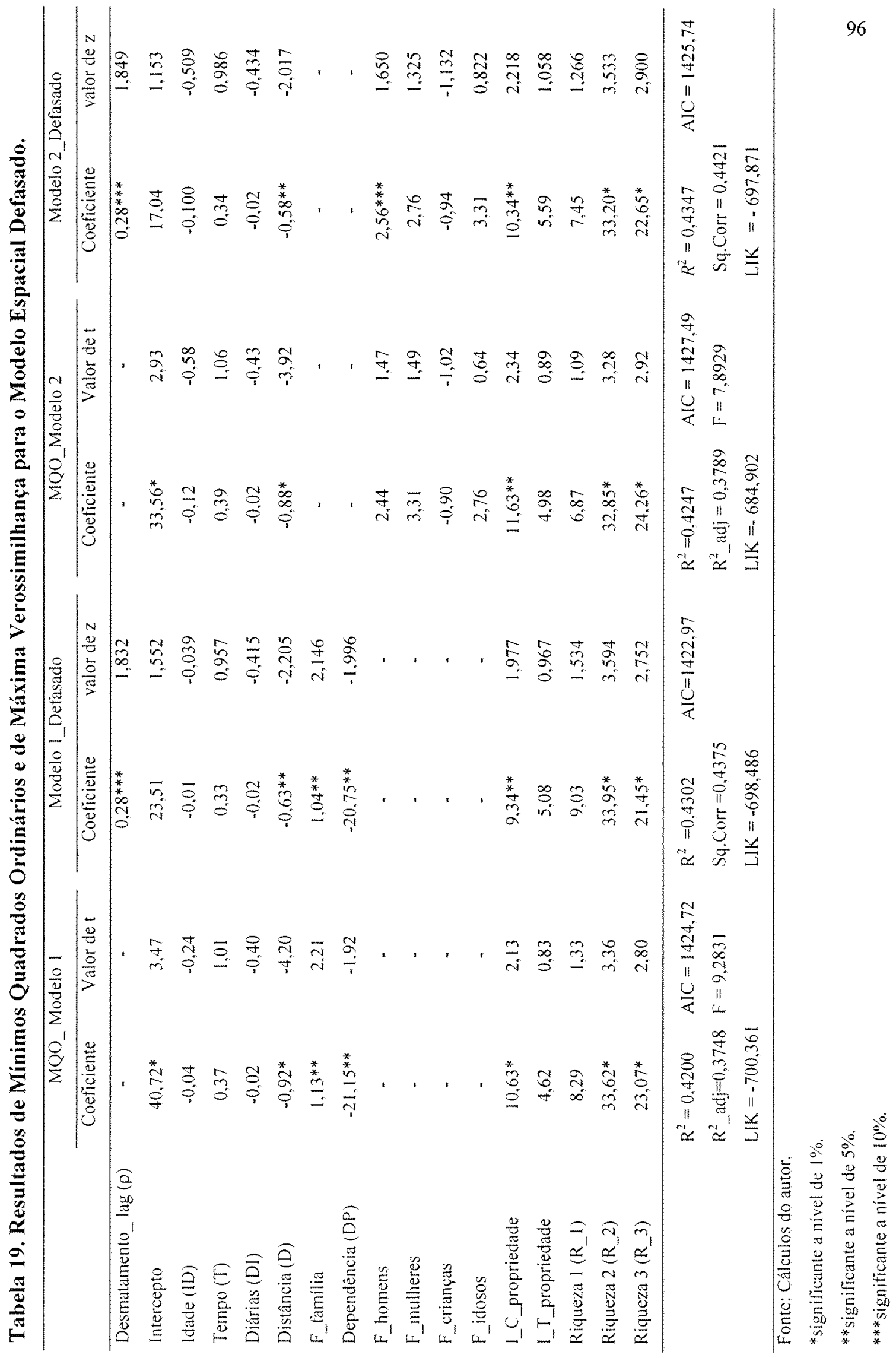


Dado que nas fases iniciais de consolidação da família na propriedade faz-se necessário efetuar algum desmatamento, e tendo em vista que algum dispêndio deve ter sido efetuado, procura-se, então, analisar os efeitos do nível de riqueza inicial da família na área total desmatada. Dessa forma, tal como esperado, constata-se que nos dois modelos propostos, o nível de riqueza inicial é um importante fator de influência sobre a área desmatada. Todavia, os resultados sugerem haver um nível mínimo de riqueza a partir do qual sua influência sobre a área desmatada é maior. Por outro lado, os resultados também sugerem que a partir de um determinado nível de riqueza, o efeito sobre o desmatamento é menor.

Muito embora pareça que características sociodemográficas, tais como tamanho da família, total de homens e dependência, sejam importantes para o processo de desmatamento, constata-se que fatores institucionais também são significantes. De fato, verifica-se que a variável crédito é estatisticamente significante nos dois modelos apresentados. Estudos anteriores têm demonstrado que a disponibilidade de crédito promove o desmatamento, uma vez que permite aos produtores aumentar a área plantada e as pastagens (Monela, 1995; Almeida \& Campari, 1995). Entretanto, Godoy et al. (1997) estudando famílias indígenas na Bolívia e em Honduras constata que a disponibilidade de crédito reduziu a área total desmatada.

Este último estudo sugere que famílias com mais acesso ao crédito podem depender menos das atividades agrícolas e envolver-se mais em atividades assalariadas, como forma de pagar seus empréstimos, tendo assim, menos tempo para atividades dentro da propriedade. Por outro lado, Pichón (1997) não encontrou significância entre o uso de crédito e desmatamento no Equador.

Com relação à variável título, verifica-se que esta não apresenta nenhuma relação com a área total desmatada. Segundo Godoy et al. (1996) e Pichón (1997), a posse definitiva da propriedade diminui o desmatamento e também a ameaça de novas invasões por pessoas estranhas à região. Entretanto, de maneira geral, o resultado encontrado não chega a surpreender, pois, observa-se na região uma certa confiança 
entre os colonos que não possuem título de propriedade de que, "cedo ou tarde", o título de posse será concedido pelo Incra, independente da área total utilizada (ou desmatada). Neste caso, verifica-se que a maioria dos colonos que não possuem a titulação do lote procura seguir o traçado estipulado no projeto original do Incra. Em outras palavras, estes colonos seguem as delimitações de tamanho impostas pelo Incra na implantação do projeto, tendo inclusive o cuidado de marcar seus lotes ao longo das estradas. 


\section{RESUMO E CONCLUSÕES}

O desmatamento na Amazônia tem ocorrido nos últimos trinta anos como conseqüência de um conjunto de políticas que, de uma maneira ou outra, incentivaram o uso da maior floresta tropical do planeta. Dentro deste conjunto de políticas, muitas estavam voltadas para a colonização da região através de pequenos produtores. Em decorrência disto, a maior parte do desmatamento que hoje ocorre na região tem sido atribuída a estes pequenos produtores.

Contudo, pouco se sabe a respeito dos efeitos das influências sociodemográficas, institucionais e de mercado sobre estas familias e como estes influenciam a tomada de decisão de desmatar. Neste contexto, o objetivo principal desta pesquisa estava centrado no entendimento das forças determinantes do desmatamento que acontece em áreas de colonização, ao longo da rodovia Transamazônica. Diferentemente de outros trabalhos já realizados, este estudo também buscou preencher um espaço na literatura ainda pouco explorado, o qual combina dados de sensoriamento remoto com dados primários coletados em campo, como uma forma de contribuição dos cientistas sociais aos estudiosos do sensoriamento remoto.

Para atingir tal fim, análises descritivas envolvendo fatores sociodemográficos, institucionais e de mercado foram elaboradas na tentativa de se avaliar seus efeitos sobre os padrões de usos da terra e sobre o desmatamento. Todavia, os resultados demonstraram que é impossível verificar os efeitos destas variáveis conjuntamente neste tipo de análise, apesar destas fornecerem "insights" sobre os padrões encontrados na região. 
Assim, dado que pouco se conhece a respeito das tomadas de decisões de uso da terra em áreas de fronteira, preconcebidas noções sobre uso da terra, focalizadas em somente uma ou duas dimensões, podem levar a um inadequado entendimento das interações existente entre cada tipo de uso. Ou seja, não se pode analisar um tipo de uso da terra isoladamente do resto, nem separar os efeitos de cada fator, pois, o desmatamento envolve uma grande variedade de atividades humanas com diferentes conseqüências.

Além disso, a qualidade dos recursos existentes na propriedade podem sofrer transformações ao longo do tempo em decorrência das estratégias de uso da terra. Neste contexto, cada tipo de decisão de uso da terra tem implicações sobre as outras decisões e uma completa análise das decisões de alocação deve levar em conta essas inter-relações. Assim sendo, fez-se necessário investigar estes efeitos em um contexto multivariado.

Contudo, a utilização de dados georreferenciados pode levar os resultados da análise multivariada a apresentarem problemas de autocorrelação, ou dependência, espacial, onde a dependência espacial pode ser considerada como a existência de um relacionamento funcional entre o que acontece em um ponto no espaço e em outros lugares. Neste caso, há a necessidade de se considerar a importância de outros fatores explicativos localizados no espaço, desconsiderados pela imposição de limites ou fronteiras na definição das unidades de análise (lotes), tais como qualidade dos solos, tipos de vegetação, etc. Neste contexto, testes de autocorrelação espacial foram realizados para o modelo proposto, sendo que essas análises sugeriram que os dois modelos testados apresentavam problemas de autocorrelação espacial subjetiva, ou seja, a área total desmatada em uma determinada propriedade influenciava a área total desmatada em outras propriedades numa vizinhança de 10.000 metros. Assim sendo, estimou-se dois modelos pelo Método de Máxima Verossimilhança para Modelos Espacialmente Defasados.

Os resultados encontrados indicam que, pelo lado institucional, a acessibilidade ao mercado e a política de crédito afetam significativamente o processo 
de desmatamento. No primeiro caso, pode-se sugerir que o estabelecimento de estradas estimula os colonos a converterem áreas de florestas para uso agropecuário. É comum na região os colonos demarcarem lotes antes da construção de estradas. Para isso, os colonos abrem apenas alguns metros na frente dos lotes demarcados como uma forma de demonstrar que aqueles lotes já possuem "dono". Contudo, com o surgimento das estradas, o processo de desmatamento se intensifica, pois abre a possibilidade da comercialização da produção, da titulação da propriedade e da possibilidade de obtenção de crédito agrícola. Assim, uma clara mensagem para os formuladores de política está centrada no fato de que o estabelecimento de estradas aumenta o desmatamento na medida que estimula os agricultores a converterem áreas de florestas em áreas agrícolas. Contudo, isto não significa que o governo deva abandonar os pequenos produtores destas áreas a sua própria sorte, mais sim deve-se ter o cuidado de planejar a criação de estradas, e a recuperação destas, considerando o meio ambiente.

No caso do crédito rural, sua importância na análise de regressão pode ser explicada pelo próprio passado histórico da região. Observa-se na área em estudo que comumente houve um beneficiamento das grandes fazendas em detrimento dos pequenos produtores. Todavia, o Banco da Amazônia (Basa) implementou uma linha de crédito destinada a ajudar os pequenos produtores. Neste caso, mesmo colonos que não possuíam título de posse, e que são comumente excluídos de outras linhas de crédito, foram elegíveis para a obtenção. Tal importância pode ser confirmada na análise descritiva efetuada anteriormente, onde cerca de $52,2 \%$ dos lotes amostrados obtiveram crédito rural, sendo que $16 \%$ deste crédito foi aplicado em pecuária e cerca de $14,2 \% \mathrm{em}$ pecuária e culturas perenes, conjuntamente.

Por outro lado, dentro deste mesmo contexto institucional, a variável título da propriedade foi estatisticamente insignificante. Entretanto, de uma maneira geral, o resultado encontrado não chega a surpreender, pois observa-se na região uma certa confiança entre os colonos que não possuem título de propriedade, e os que "cedo ou tarde" receberão o título de posse concedido pelo Incra independente da área total utilizada (ou desmatada). 
Muito embora os fatores institucionais e de mercado sejam importantes para o processo em estudo, são apenas uma parcela da complexa interação que existe. Portanto, considerando-se as variáveis que diretamente refletem estágios do ciclo de vida da família, tais como idade do chefe da família, tempo de residência na propriedade, dependência e tamanho da força de trabalho, apenas as últimas duas parecem influenciar a área desmatada, nos dois modelos propostos.

Dado que nas fases iniciais de consolidação da família na propriedade faz-se necessário efetuar algum desmatamento, e tendo em vista que algum dispêndio deve ter sido efetuado, procurou-se, então, analisar os efeitos do nível de riqueza inicial da família na área total desmatada. Dessa forma, tal como esperado, constatou-se que nos dois modelos propostos, o nível de riqueza inicial é um importante fator de influência sobre a área desmatada. Todavia, os resultados sugerem haver um nível mínimo de riqueza a partir do qual sua influência sobre a área desmatada é maior. Por outro lado, os resultados também sugerem que a partir de um determinado nível de riqueza, o efeito sobre o desmatamento é menor.

A discussão aqui estabelecida apresenta a idéia de que as relações entre os fatores sociodemográficos, institucionais e de mercado com o desmatamento na região amazônica podem ser mais complexas do que se imaginava. Além disso, demonstra-se a importância que a estrutura da família e a acessibilidade ao mercado têm na tomada de decisão de uso da terra e que, dada a heterogeneidade e complexidade dos fatores ecológicos e sociais existentes, qualquer política governamental, ou tecnologia, para ser efetiva deveria primeiramente analisar as tomadas de decisões existentes sobre o uso da terra.

Neste contexto, as pesquisas devem centrar-se em identificar sistemas agrícolas economicamente e ecologicamente sustentáveis e consistentes com as diferentes situações e capacidade administrativa dos colonos. Todavia, deve-se ter em mente a importância dos fatores demográficos no ciclo de vida da família e de sua influência na tomada de decisão de uso da terra. Assim sendo, é preciso pensar a 
colonização da Amazônia de uma forma cuidadosa, baseada em pesquisa, bem como em estratégias que envolvam um grande espectro de iniciativas não só na área em estudo, mas também nas áreas de origem dos colonos, de tal forma a fornecer bases para o planejamento racional do uso da terra na região.

Finalmente, ressalta-se três pontos importantes: o primeiro está relacionado à importância deste trabalho. Apesar da aparente utilidade no uso de dados de sensoriamento remoto nas ciências sociais, este não tem sido popular entre os cientistas sociais brasileiros. Neste contexto, este estudo buscou preencher uma lacuna ainda existente nas pesquisas sociais brasileiras. Em segundo lugar, os resultados sugerem que os modelos de desmatamento que omitem dados em nível de família podem estar malespecificados. Em terceiro lugar, verifica-se que uma das limitações da presente análise está relacionada ao uso de dados "cross sections", que não permitem um detalhado estudo das famílias ou da propriedade ao longo do tempo. Ou seja, entrevistas realizadas entre os colonos sugerem que a demanda por novas áreas está associadas a uma complexa estrutura que existe entre as gerações de colonos e que não são abordadas no estudo. Análises adequadas exigiriam informações longitudinais, preferivelmente envolvendo as mesmas famílias, ao longo do tempo, de tal forma a gerar magnitudes do desmatamento para diferentes anos. Dados de sensoriamento remoto poderiam então ser combinados com dados primários e relacionados aos impactos macroeconômicos de tal forma que permitissem avaliar o efeito das políticas formuladas fora do domínio da família sobre a tomada de decisão de uso da terra. 


\section{REFERÊNCIAS BIBLIOGRÁFICAS}

ANDERSEN, L.E. The causes of deforestation in the Brazilian Amazon. Journal of Environment and Development, v.5, n.3, p.309-328, 1996.

ANDERSEN, L.E.; REIS, E.J. Deforestation, development and government policy in the Brazilian Amazon: an econometric analysis. Brasilia: IPEA, 1997. 24 p. (Texto para Discussão, 513)

ALMEIDA, A.L.O.; CAMPARI, J.S. Sustainable settlement in the Brazilian Amazon. New York: Oxford University Press, 1995. 185 p.

ALMEIDA, A.L.O.; SANTOS, C.F.V. A colonização particular na Amazônia nos anos 80. Rio de Janeiro: Instituto de Pesquisa Econômica Aplicada, 1990. 88 p. (Texto para Discussão, 208)

ALLEN, J.C.; BARNES, D.F. The causes of deforestation in developing countries. Annals of the Association of American Geographers, v.75, n.2, p.163-184, 1985.

ALVIM, P.T. Perspectivas de produção agrícola na região amazônica. Interciência, v.3, n.4, p.243-249, 1978.

ANSELIN, L. Spatial Econometrics: methods and models. The Netherlands: Kluwer Academics Publishers, 1988. 284 p.

ANSELIN, L.; GRIFFITH, D.A. Do spatial effects really matter in regression analysis? Regional Science Association Papers, n.65, p.11-34, 1988. 
ANSELIN, L.; REY, S. Properties of tests for spatial dependence in linear regression models. Geographical Analysis, v.23, n.2, p.112-131, 1991.

BARRACLOUGH, S.; GHIMIRE, $\mathrm{K}$. The social dynamics of deforestation in developping countries: principal issues and research priorities. Washington: United Nations Research Institute for Social Development, 1990. 46 p. (Discussion Paper, 16)

BONAL, P. et al. Os pequenos e médios produtores do município de Silvânia -Estado de Góias: características gerais e tipologia das explorações. Goiânia: EMBRAPA/CPAC, $1993.42 \mathrm{p}$.

BOSERUP, E. The conditions of agricultural growth: the economics of agrarian change under population pressure. London : George Allen \& Unwin, 1965. $124 \mathrm{p}$.

BRASIL, M.C.; McCRACKEN, S.D. Extrativist households and their subsistence strategies: a case study of the Island of Marajó, 15 p. / Presented at Annual Meeting of the Population Association of America, New Orleans, 1993/

BROWDER, J. Surviving in Rondônia: the dynamics of colonist farming strategies in Brazil's northwest frontier. Studies in Comparative International Development, v.29, n.3, p.45-69, 1994.

BROWDER, J. Public policy and deforestation in the brazilian Amazon. In: REPETTO, R.; GILLIS, M. (Eds.). Public policies and the misuse of forest resources. Cambrigde: Cambrigde University Press, 1988. 432 p.

BROWN, K.; PEARCE, D.W. The causes of tropical deforestation: the economics and the statistical analysis of factors giving rise to the loss of the tropical forest. Vancouver: University of British Columbia Press, 1994. 329 p.

BURGUESS, J. C. Timber production, timber trade and tropical deforestation. AMBIO, n.22, p.136-143, 1993. 
CAPISTRANO, A.D. Macroeconomics influences of tropical forest depletion: a crosscrountry analysis. Gainesville, 1990. 218 p. Dissertation (Ph.D.) - University of Florida.

CHOMITZ, K.M.; GRAY, D. A roads, lands, markets, and deforestations : a spatial model of land use in Belize. World Bank Economic Review, v.10, p.487-512, 1996.

CJ JEPMA. Tropical deforestation: a socio-economic approach. London: Earthscan Publications, $1995.316 \mathrm{p}$.

CLIFF, A.; ORD, K. Testing for spatial autocorrelation among regression residuals. Geographical Analysis. v.14, p.267-84, 1972.

COCHRANE, D.; ORCUTT, G.H. Applications of least square regressions to relationships containing autocorrelated error terms. Journal of the American Statistical Association, v.44, n.3, p.32-61, 1949.

DESHAZO, R.A.P. Deforestation in the ecuadorian Amazon: household-level determinants. Chapel Hill, 1993. 157 p. Thesis (Master) - University of North Caroline.

DOREIAN, P. Linear models with spatially distributed data: spatial disturbance or spatial effects ? Sociological Methods and Research, n.9, p.29-66, 1980.

DUCK, A.; BLACK, G. A. Notas sobre a fitogeografia da Amazônia brasileira. Belém : Instituto Agronômico do Norte, 1954. 40 p. (Boletim Técnico, n.4)

ELLIS, F. Peasant economics: farm household and agrarian development. New York : Cambridge University Press, 1993.297 p.

EMPRESA BRASILEIRA DE PESQUISA AGROPECUÁRIA. Mapa esquemático dos solos das Regiões Norte, Meio-Norte e Centro-Oeste do Brasil. Rio de Janeiro : EMBRAPA, 1975. 48 p. (Boletim Técnico, 17). 
FEARNSIDE, P.M. Environmental change and deforestation in the Brazilian Amazon. In: Change in the Amazon Basin: man's impact on the forest and rivers. Manchester: Manchester University Press, 1985. p.70-89.

FEARNSIDE, P.M. Human use systems and the causes of deforestation in the Brazilian Amazon, 36 p. / Presented at the International Conference on Climate, Biotic and Human Interactions in the Humid Tropics: vegetation and climate interaction in Amazonia, São José dos Campos, 1985a/

GODOY, R.; FRANK, J.R.; CLAÚDIO, M.A. Adoption of modern agricultural technologies by lowland indigenous groups in Bolivia: the role of households, villages, ethnicity and markets. Human Ecology, v.26, n.3, p.351-369, 1998.

GODOY, R.; O'NEILL, K.; GROFF, S. et al. Household determinants of deforestation by Amerindians in Honduras. World Development, v.25, n.6, p.977-987, 1997.

GODOY, R.; BROKAW, N.; WILKE, D. et al. Rates of return on investments in cattle among Amerindians of the rain forest of Honduras. Human Ecology, v.24, n.3, p.395399, 1996.

GRIFFITH, D.A. Advanced spatial statistic: special topics in the exploration of quantitative spatial data series. The Netherlands: Kluwer Academic Publishers, 1988. $273 \mathrm{p}$.

HECHT, S.B. Environment, development and politics: capital accumulation and the livestock sector in eastern Amazonia. World Development, v.13, p.663-684, 1985.

HECHT, S.B.; COCKBURN, A. The fate of the forest: developers, destroyers and defenders of the Amazon. New York : Verso, 1989.266 p.

HIRAOKA, M.; YAMAMOTO, S. Agricultural development in the upper Amazon of Ecuador. Geographic Review, v.70, p.423-445, 1980. 
HOLDEN, S.T.; TAYLOR, J.E.; HAMPTON, S. Structural adjustment and market imperfections: a stylized village economy-wide model with non-separable farm households. Agricultural University of Norway, 1997.33p. (Department of Economics and Social Sciences. Discussion Paper D-29)

INSTITUTO BRASILEIRO DE GEOGRAFIA E ESTATISTICA. Censo Demográfico. Rio de Janeiro : IBGE, 1996.

INSTITUTO DE PESQUISA E EXPERIMENTAÇÃO AGROPECUÁRIA DO NORTE. Contribuição ao estudo dos solos de Altamira. Belém, 1967. 15 p. (Circular, 10)

KAHN, J.R.; McDONALD, J.A. International debt and deforestation. In: BROWN, K.; PEARCE, D. (Eds.). The causes of tropical deforestation: the economic and statistical analysis of factors giving rise to the loss of tropical forest. London: University College of London Press, 1994. 338 p.

KAIMOWITZ, D.; ANGELSEN, A. Economic models of tropical deforestation: a review. Jakarta: Center of International Forestry Research, 1998. 135 p.

KANT, S.; REDANTZ, A. An econometric model of tropical deforestation. Journal of Forestry Economics, v.3, p.51-86, 1997.

KATZMAN, M.T. Cities and frontiers in Brazil. Harvard University Press, 1977. 255 p.

KING, M. L. Testing for autocorrelation in linear regression models: a survey. In: KING, M.L.; GILES, D. (Eds.). Specification analysis in the linear model. London: London Press, $1987.320 \mathrm{p}$.

KRUG, T. Space technology and environmental monitoring in Brazil. Journal of International Affairs, v.51, n.2, p.655-674, 1998.

KUMMER, D.M.; SHAM, C.H. The causes of tropical deforestation: a quantitative analysis and case study from the Philippines. In: BROWN, K.; PEARCE, D. (Eds.). The causes of tropical deforestation, the economic and statistical analysis of 
factors giving rise to the loss of tropical forests. London: University College London Press, 1994. 318p.

LIVERMAN, D.; MORAN, E.F.; RINDFUSS, R.R.; STERN, P.C. People and Pixels: liking remote sensing and social science. Washington: National Academy Press, 1998. $244 \mathrm{p}$.

LIU, D.S; IVERSON, L.R.; BROWN, S. Rates and patterns of deforestation in the Philippines: applications of geographic information system analysis. Forest Ecology and Management, n.57, p.1-16, 1993.

LUGO, A.E.; SCMIDT, R.; BROWN, S. Tropical forests in the caribbean. AMBIO, v.10, n.6, p.318-324, 1981.

MAHAR, D.J. Government policies and deforestation in Brazil's amazon region. Washington: World Bank, 1989.40 p.

MAHAR, D.J.; DUCROT, C.E.H. Land use zoning on tropical frontiers: emerging lessons from the Brazilian Amazon. Washington: World Bank. Economic Development Institute, 1998. 25 p. (EDI Case Studies)

MAMINGI, N.; CHOMITZ, K.M.; GRAY, D.A; LAMBIM, E.F. Spatial patterns of deforestation in Cameroon and Zaire. Washington: World Bank, 1996. 37p. (Research Project on Social and Environmental Consequences of Growth-Oriented Policies. Policy Research Department, Working Paper 8)

MARQUETTE, C. Land use patterns among small farmer settlers in the northeastern Ecuadorian Amazon. Human Ecology, v.26, n .4, p.573-598, 1998.

McCRACKEN, S.D.; SIQUEIRA, A.; MORAN, E.F.; BRONDIZIO, E. Domestic life course and land use patters in an agricultural frontier in Brazil, $25 \mathrm{p}$. /Paper presented at Conference on Patterns and Processes of Land Use and Forest Change, University of Florida, March 23-26, 1999/ 
MERTENS, B.; LAMBIM, E.F. Spatial modeling of deforestation in Southern Cameroon: spatial disaggregation of diverse deforestation process. Applied Geography, v.17, p.143-168, 1997.

MONBIOT, G. Brazil: land ownership and flight to Amazonia. In: The Struggle for the land and the fate of the forest. New Jersey: Marcus Colchester and Larry Lohmann, $1995.389 \mathrm{p}$.

MONELA, G.C. Tropical rainforest deforestation, biodiversity benefits, and sustainable land use: analysis of economic and ecological aspects related to the Nguru Mountains, Tanzania. 1995. 155p. Dissertation (Ph.D.) - Agricultural University of Norway.

MORAN, E. Developing the Amazon: the social and ecological consequences of government-directed colonization along Brazil's Transamazon Highway. Bloomington: Indiana University Press, 1981.292 p.

MORAN, E.; BRONDIZIO, E. Land use change after deforestation in Amazonia. In: People and Pixels: linking remote sensing and social science. Washington: National Research Council, 1998. p.94-120.

MORAN, E.; PACKER, A.; BRONDIZIO, E.; TUCKER, J. Restoration of vegetation cover in the eastern Amazon. Ecological Economics, v.18, n1, p.41-54, 1996.

MUÑOZ, C.P. Forest or no forest, a logit model of land use in Mexico. London, 1992. 170p. Thesis (Master) - University College of London.

MYERS, N. The present status and the future prospects of tropical moist forest. Environmental Conservation. v.7, p.101-114, 1980.

NAKAJIMA, C. Subsistence and commercial family farms: some theoretical models of subjective equilibrium. In: Subsistence agriculture and economic development. C.R WartonChicago: Aldine Published Company, 1969. p.165-185. 
NATIONAL RESEARCH COUNCIL. Sustainable agriculture and the environment in the humid tropics. Washington: National Academy Press, 1993. $702 \mathrm{p}$.

ODLAND, J. Spatial autocorrelation. London: Sage Publications, 1988. 86p.

ORD, K. Estimation methods for models of spatial interaction. Journal of American Statistical Association, v.70, p.120-126, 1975.

PFAFF, A.S.P. What drives deforestation in the Brazilian Amazon? Journal of Environmental Economics and Management, v.37, p.26-43, 1999.

- PICHÓN, F.J. Agricultural settleman, land use and deforestation in the Ecuadorian Amazon frontier: a microlevel analysis of colonist's land allocation behavior. Chapel Hill, 1993, 291 p. Dissertation (Ph.D.) - University of North Caroline.

PICHÓN, F.J. Colonist land allocation decisions, land use and deforestation in the Ecuadorian Amazon frontier. Economic Development and Cultural Change, v.35, n.3, p.707-744, 1997.

PICHÓN, F.J.; BILSBORROW, R. Land use systems, deforestation and associated demographic factors in the humid tropics: farm level evidence from Ecuador, $31 \mathrm{p}$. /Paper presented at IUSSP Committee on Population and Environment Seminar on Population and Deforestation in the Humid Tropics, Campinas, Nov.30 - Dec.3, 1992/

PIRES, J.M.; PRANCE, G.T. The vegetation types of the Brazilian Amazon. In: PRANCE, G.T.; LOVEJOY, T.E. (Eds.). Key Environments: Amazonia. New York : Pergamon Press, 1985. p.109-145.

REIS, E.J.; GUZMÁN, R.M. An econometric model of Amazon's deforestation. Brasília: Instituto de Pesquisa Econômica Aplicada, 1992. 27 p. (Texto para Discussão, 265) 
REIS, E.J.; MARGULliS, S. Perspectivas econômicas do desflorestamento da Amazônia. Brasília: Instituto de Pesquisa Econômica Aplicada, 1991. 47 p. (Texto para Discussão, 215)

ROSERO-BIXBY, L.; PALLONI, A. Population and deforestation in Costa Rica, 26 p. /Paper presented at the Annual Meeting of The Population Association of America, New Orleans, 1996/

RUDEL, T.K. Population, development, and tropical deforestation: a cross national study. Rural Sociology, v.54, p.327-338, 1989.

RUDEL, T. R.; HOROWITZ, B. Tropical deforestation: small farmers and land clearing in the Ecuadorian Amazon. New York: Columbia University Press, 1993. 243 p.

SCHMINK, M.; WOOD, C. Frontier expansion in Amazonia. Florida: University of Florida Press, 1984. 502 p.

SCHMINK, M.; WOOD, C. Contested frontier in Amazonia. New York: Columbia University Press, 1993. $387 \mathrm{p}$.

SERRÃO, E.A.S.; HOMMA, A.K.O. Brazil. In: Sustainable agriculture and the environment in the humid tropics. Washington: National Academy Press, 1993. $702 p$.

SERRÃO, E.A.S.; NEPSTAD, D.; WALKER, R.T. Upland agricultural and forestry development in the Amazon: sustainability, criticality and resilience. Ecological Economics, v.18, p.3-13, 1996.

SINGH, I.; SQUIRE, L.; STRAUSS, J.L. The basic model: theory, empirical results and policy considerations. In: Agricultural Household Models. Baltimore: The John Hopkins University Press, 1986. 91 p.

SILBERBERG, E. The structure of economics: a mathematical analysis. New York: McGraw-Hill, 1990. 686p. 
SILVA, L.F. et al. Solos do Projeto Ouro Preto. Bahia. Comissão Executiva do Planejamento da Lavoura Cacaueira, 1973. 10 p. (Boletim Técnico, 23).

SIOLI, H. The Amazon and its main affluent: hydrology, morphology of the river courses and rivers types. In: The Amazon: limmology and landscape ecology of a might tropical river and its Basin. The Netherlands: Dordrecht, 1984. p.127-165.

SKILLINGS, R.F.; TCHEYAN, N.O. Economic development prospects of the amazon region of Brazil. Washington: The John Hopkins Press, 1979. 98 p.

SKOLE, D.L.; CHOMENTOWSKI, W.H; SALAS, W.A.; NOBRE, A.F. Physical and human dimensions of deforestation in Amazonia. BioScience, v.44, n.5, p.314-322, 1994.

SLAVER, C. Why farmers rotate fields in maize-cassava-plantain bush fallow agriculture in the wet Peruvian amazon. Human Ecology, v.17, n.4, p.401-425, 1989.

SMITH, N. Colonization lesson from a tropical forest. Science, v.214, n.3, p.755-761, 1981.

SOUTHGATE, D.; SIERRA, R.; BROWN, L. The causes of tropical deforestation in Ecuador: a statistical analysis. World Development, v.19, n.9, p.1145-1151, 1991.

SYDENSTRICKER, J.; VOSTI, S.A. Household size, sex composition, and land use in tropic moist forest: evidence from the Machadinho Colonization Project, Rondônia. Brazil, 18 p. /Paper presented at 1993 Meeting of the Population Association of America, 1-3 April, Cincinnati, OH./

THAPA, K.K.; BILSBORROW, R.E.; MURPHY, L. Deforestation, land use and women's agricultural activities in the Ecuadorian Amazon. World Development, v.24, n.8, p.1317-1332, 1996.

TORNER, D.; KERBLAY, B.; SMITH, R.E.F. The theory of peasant economy. Wisconsin: The University of Wisconsin Press, 1986. 300 p. 
TURNER II, B.L.; MEYER, W.B.; SKOLE, D.L. Global land use / land cover change: towards an integrated study. Ambio, v.23, n.1, p.91-95, 1994.

* WALKER, R.T. Land use transition and deforestation in development countries. Geographical Analysis, v.19, p.18-30, 1987.

WALKER, R.T.; HOMMA, A.K.O. Land use and land cover dynamics in the Brazilian Amazon: an overview. Ecological Economics, v.18, n.1, p.67-80, 1996.

WALKER, R.T.; SMITH, T.E. Tropical deforestation and forest management under the system of concession logging: a theoretical decision analysis. Journal of Regional Science, v.33, n.3, p.387-419, 1993.

WALKER, R. T.; MORAN, E.; ANSELIN, L. Deforestation and cattle ranching in the Brazilian Amazon: external capital and household process. World Development, v.8, n. 4, p. $683-699,2000$.

WALKER, R.T.; PERZ, S.; CALDAS, M.M.; SILVA, L.G.T. Land use and land cover change in forest frontier: the role of household life cycle. International Journal of Regional Science. (no prelo)

WATTERS, R.F. Shifting cultivation in Latin America. Rome, 1971. 303 p. (Food and Agriculture Organization of United Nations. Forestry Development Paper, 17)

WEAR, D.N.; BOLSTAD, P. Land use changes in southern Appalachian Landscapes: spatial analysis and forecast evaluation. Ecosystems, v.1, p.575-594, 1998.

WOOD, C.; SKOLE, D.L. Linking satellite, census, and survey data to study deforestation in the Brazilian Amazon. In: People and Pixels: linking remote sensing and social science. Washington: National Research Council, 1998 p.70-94. 
APÊNDICE A 


\section{APÊNDICE A \\ QUESTIONÁRIO}

\section{Data}

${ }^{1}$ Questionário no.

${ }^{2}$ Entrevistador

${ }^{3}$ Nome do Produtor e/ou Entrevistado

\section{Localização e Condição do Entrevistado}

${ }^{4}$ a) Município

${ }^{5}$ b) Travessão

${ }^{6}$ d) Lote

\section{Relacão de posse: Verificar se é proprietário}

(Se for arrendatário ou parceiro sai da mostra)

${ }^{7}$ Condição do entrevistado:
a) chefe
( )
b) esposa
( )
c) filho
( )
d) outro

\section{Migracão, História Pessoal (Chefe do domicílio)}

${ }^{8}$ Idade?

anos

${ }^{9}$ Desde quanto tempo mora aqui? anos meses

${ }^{10}$ Em que Estado nasceu?

${ }^{11}$ Chegou aqui vindo de que Estado

${ }^{12}$ Chegou aqui vindo de que município

${ }^{13}$ Chegou aqui de uma zona:

${ }^{14}$ Antes de vir aqui, trabalhava como?

Rural ( ) Urbana

Proprietário rural

Arrendatário

Meeiro

Diarista

Posseiro

Assalariado

Outro 
15 Anos que freqüentou escola?

Informacões gerais sobre as propriedades:

16 Tem residência urbana também? Sim ( ) Não ( )

${ }^{17}$ Quantas propriedades possui?

Mão de Obra (da unidade doméstica do entrevistado)

${ }^{18}$ Número de pessoas que moram no lote:

${ }^{19}$ Número de homens 16-65 anos:

${ }^{20}$ Número de mulheres 16-65 anos

${ }^{21}$ Número de crianças $0-14$ anos

${ }^{22}$ Número de idosos $>65$ anos

${ }^{23}$ Quantas diárias pagou no último ano?

\section{Outras fontes de renda}

${ }^{24}$ Membros da família fora da fazenda contribuem?

${ }^{25}$ Outras fontes de renda

FUNRURAL

Atividade Comercial

Contribuição de terceiros

Outra

$26 \%$ das outras contribuições:

na renda total da propriedade

$\operatorname{Sim}(\quad$ Não $(\quad)$

$\operatorname{Sim}(\quad$ ) Não ( )

$\operatorname{Sim}($ ) Não ( )

$\operatorname{Sim}(\quad$ ) Não ( )

$-50 \%(\quad)+\operatorname{de} 50 \%(\quad)$

\section{Condição Econômica da Família, da Casa, da fazenda}

Disponibilidade de bens pela família:

$\stackrel{\text { no início }}{\text { Sim Não } \quad \text { Sim Não }}$

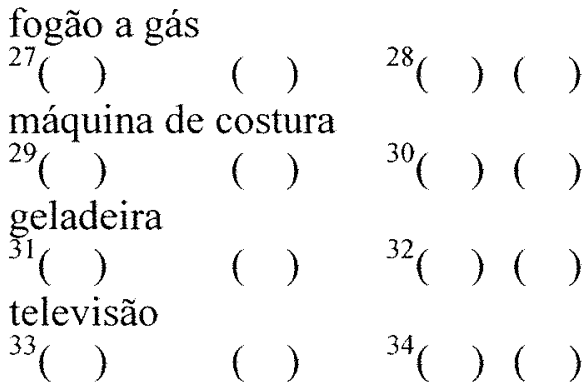


antena parabólica

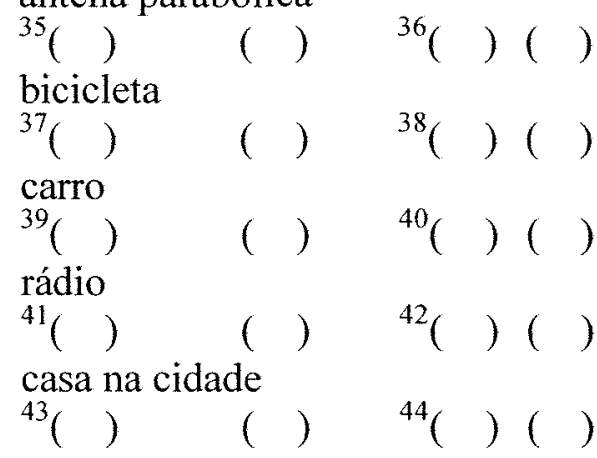

Casa onde mora a família

Máquinas e equipamentos

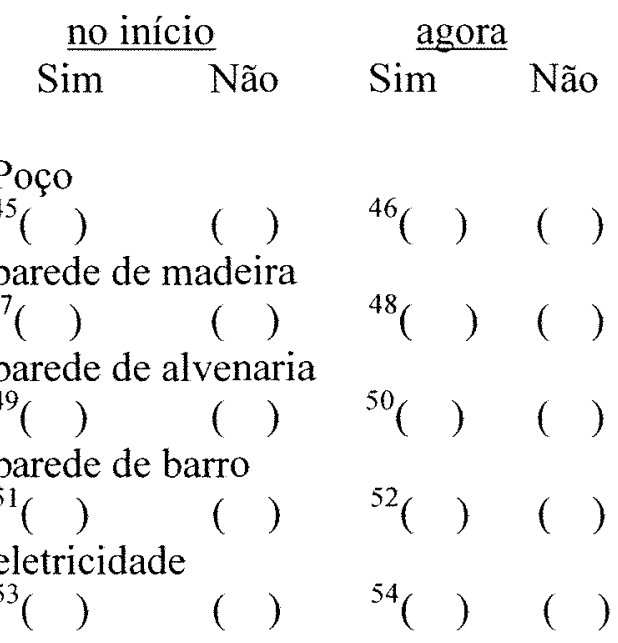

$\frac{\text { no início }}{\operatorname{Sim} N a ̃ o} \quad \operatorname{Sim}^{\frac{a g o r a}{\text { Não }}}$

motosserra

${ }^{57}(\quad)$

gerador

$59($ )

secador de cacau

${ }^{61}(\quad)$

trator

${ }^{63}(\quad)$

carro

${ }^{65}(\quad)$

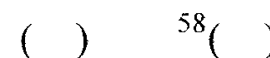

${ }^{60}() \quad(\quad)$

${ }^{62}()(\quad)$

${ }^{64}() \quad(\quad)$

${ }^{66}() \quad(\quad)$ 


\section{Consumo e alocacão de mão-de-obra}

$\%$ consumida no ano anterior (do total da produção)

${ }^{67}$ arroz
$\frac{{ }^{68} \text { feijão }}{{ }^{69} \text { milho }}$
${ }^{70}$ mandioca
${ }^{71}$ outro

Aproximadamente que \% de tempo, no decurso de um ano, é utilizado Usando trabalho familiar e de terceiros?

$\%$ de tempo

${ }^{72}$ anuais

${ }^{73}$ perenes

${ }^{74}$ pecuária

Planos para o futuro

${ }^{75}$ aumentar/mudar de casa

${ }^{76}$ instalar poço

77 adquirir financiamento

${ }^{78}$ adquirir propriedades

${ }^{79}$ comprar equipamento

${ }^{80}$ Se tiver recursos, qual seria o investimento mais importante que o senhor faria?

(a)

(b) (c)

\section{Conflitos}

${ }^{81}$ Há ou houve disputas em relação aos

limites da suas terras?

$\operatorname{Sim}(\quad$ ) Não ( )

${ }^{82}$ Esse conflito foi devido a:

problemas de limites ( ) entrada de fogo ( ) invasão de posseiros

${ }^{83}$ Há ou houve disputas em relação aos limites das terras nesta área?

(Uruará; Altamira)

Sim ( ) Não ( ) 
${ }^{84}$ Caso sim, a quantos quilômetros?

${ }^{85}$ Como são resolvidas essas disputas?

vigilância pessoal

polícia

discussão na associação/comunidade

advogados

chamar o Incra

outro 


\section{Lote 1: Página 1}

${ }^{1}$ Em que ano adquiriu?

Qual a área da propriedade:

$$
\begin{aligned}
& 2 \text { área inicial? } \\
& 3 \text { área atual? }
\end{aligned}
$$

Ocupação e titulação da propriedade

${ }^{4}$ Como o senhor obteve essa área? Comprou

Trocou por outra área

Invadiu

Herança

Recebeu do Incra

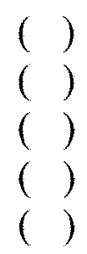

${ }^{5}$ Este lote é titulado?

Sim

${ }^{6}$ Condição do título: Provisório

Definitivo

${ }^{7}$ Emitido pelo:

$\overline{\text { (e.g., Incra; Iterpa) }}$

${ }^{8}$ Há quanto tempo?

${ }^{9}$ Já comprou com título

Não

Processo de titulação

${ }^{10}$ Quando pretende obtê-lo?

"Condição

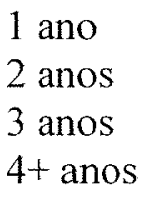

Não em processo

${ }^{12}$ Foi demarcado?

Sim

Não

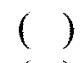

${ }^{13}$ O senhor é o primeiro ocupante deste lote?

$\operatorname{Sim}$

Não

Não sabe

${ }^{14}$ Condições de acesso: péssimas regulares, sazonalmente ruins 


\section{Lote 1: Página 2}

Situação na época

(Indicar se respondeu em $\%$ ou hectares)

$\begin{array}{rlrl}\text { da sua chegada: }{ }_{18}^{16}[ & {[\text { ha }][\%] \text { mata fechada }} & \text { hoje }{ }^{17}[ & {[\text { ha }][\%] \text { mata fechada }} \\ { }^{20}[ & {[\text { ha }][\%] \text { parte agricultável }} & { }^{19}[ & [\text { ha] }] \%] \text { parte agricultável } \\ { }^{22}[ & [\text { ha }][\%] \text { pasto }][\%] \text { capoeira } & { }^{21}[ & {[\text { ha }][\%] \text { pasto }} \\ & { }^{23}[ & {[\text { ha }][\%] \text { capoeira }}\end{array}$

Financiamento e assistência técnica

${ }^{24}$ Este lote pode ser oferecido como garantia de empréstimo?

Sim

Não

${ }^{25}$ Tem ou já teve financiamento?

Sim

Não

Caso sim:

$$
\begin{aligned}
& \text { Agricultura } \\
& { }^{28} \text { pecuaria } \\
& { }^{29} \text { máquinas e equipamentos } \\
& { }^{30} \text { outro }
\end{aligned}
$$

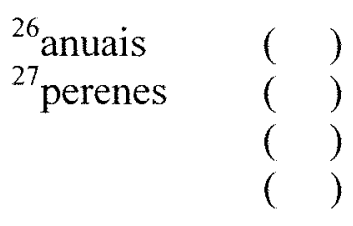

${ }^{31}$ O senhor já teve ajuda do governo (sementes, assistência técnica) Sim

${ }^{32}$ Caso sim, de que tipo?

Não

Sistemas de produção de culturas anuais e perenes

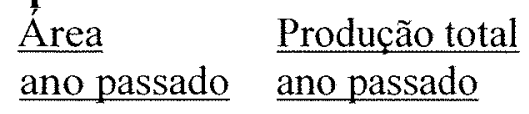

anuais

arroz

feijão

milho

mandioca

outro

perenes

cacau

café

pimenta

laranja

cana-de-açúcar ${ }^{5}$

seringueira

outro (a)

outro (b)

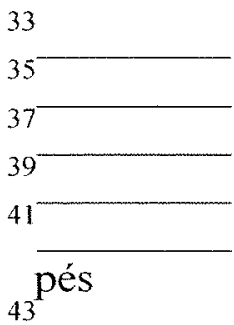

34

36

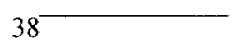

$4 0 \longdiv { - 1 2 }$

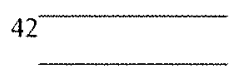

44
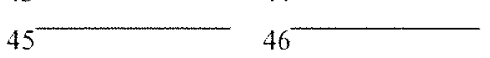

47

49

$51 \longrightarrow$

53

$55^{-}$

57

48

48

$5 0 \longdiv { \square }$

52

$5 4 \longdiv { - }$

$58 \longrightarrow$ 


\section{Lote 1: Página 3}

${ }^{59}$ pastagem total

Pecuária e pastagem

$$
\begin{aligned}
& { }^{60} \text { ativa } \\
& { }^{61} \text { abandonada } \\
& { }^{62} \text { destocada }
\end{aligned}
$$

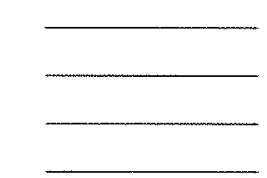

Quantas cabeças de gado

$$
{ }^{64} \text { hoje }
$$

${ }^{65}$ renovação com adubação periódica

${ }^{66}$ roçagem periódica?

${ }^{67}$ coloca fogo

anualmente

cada 2 anos

mais de 2 anos

${ }^{68}$ curral de gado

${ }^{69}$ quilômetros de cerca

\section{Desmatamento, Uso de Capoeira, Reflorestamento}

${ }^{70}$ área desmatada quando chegou?

${ }^{71}$ área desmatada agora?

${ }^{72}$ Geralmente, quantos anos deixa em posio antes de derrubar capoeira de novo?

${ }^{73}$ Como é feita a queimada? queima depois de uma chuva faz aceiros queima "meio seca" não faz controle bem seca

$\operatorname{Sim}(\quad$ ) Não ( )

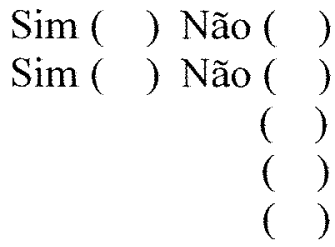


${ }^{76} \mathrm{Faz}$ reflorestamento no lote?

Sim ( ) Não ( )

espécie 1 espécie 2 espécie 3

Caso sim: quantas árvores?

77

78

79

Quantos hectares?

80

81

- 


\section{Lote 1: Página 4}

Insumos e Medicamentos nas culturas e criacões

${ }^{83}$ inseticida

$\operatorname{Sim}($ ) Não ( )

${ }^{84}$ fungicida

$\operatorname{Sim}($ ) Não ( )

${ }^{85}$ herbicida

$\operatorname{Sim}($ ) Não ( )

${ }^{86}$ adubo químico

$\operatorname{Sim}($ ) Não ( )

${ }^{87}$ adubo orgânico

$\operatorname{Sim}($ ) Não ( )

${ }^{88}$ vacina/antibiótico

$\operatorname{Sim}($ ) Não ( )

${ }^{89}$ sal mineral

$\operatorname{Sim}($ ) Não( )

\section{Uso da Floresta}

${ }^{90}$ Tinha madeira de valor comercial no lote quando o senhor chegou? Sim ( ) Não ( )

${ }^{91}$ Ainda tem madeira de valor comercial no lote? $\quad \operatorname{Sim}(\quad)$ Não ( )

${ }^{92}$ Caso sim, o senhor pretende tirar tudo o mais rápido possível

Manter como reserva, e só tirar quando for necessário

\section{Fertilidade do solo:}

${ }^{93}$ Houve perda de fertilidade?

$\operatorname{Sim}(\quad)$ Não ( )

${ }^{94}$ Caso sim,

o que o senhor fez?

promoveu rotação de áreas

promoveu rotação de culturas

promoveu adubação e correção do solo

desmatou para obter novas áreas agricultáveis

formou pasto para criação

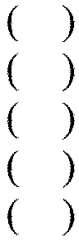

\section{Valor da terra}

${ }^{95}$ Pensa em vender a terra em algum momento?

$\operatorname{Sim}($ ) Não( )

${ }^{96}$ Pensa em deixar a terra de herança $\operatorname{Sim}($ ) Não ( )

${ }^{97}$ Venderia esta propriedade por quanto? 


\section{Lote 1: Página 5}

\section{Planos para o futuro (este lote)}

${ }^{98}$ No ano que vem, tem planos para: construir curral adicionar cerca aumentar anuais reduzir anuais aumentar perenes reduzir perenes aumentar pecuária derrubar mata deixar terra descansar tirar madeira

Notas adicionais: 